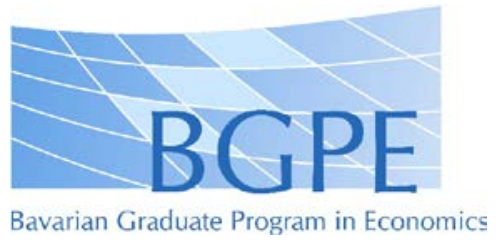

BGPE Discussion Paper

No. 169

\title{
Institutional reforms and an incredible rise in old age employment
}

\author{
Regina T. Riphahn \\ Rebecca Schrader
}

May 2017

ISSN 1863-5733

Editor: Prof. Regina T. Riphahn, Ph.D.

Friedrich-Alexander-University Erlangen-Nuremberg

(c) Regina T. Riphahn, Rebecca Schrader 


\title{
Institutional reforms and an incredible rise in old age employment
}

\author{
Regina T. Riphahn ${ }^{\mathrm{a}, \mathrm{b}}$ \\ Rebecca Schrader \\ Friedrich-Alexander University Erlangen-Nürnberg
}

April 29, 2017

We investigate whether a cut in unemployment benefit payout periods affected older workers' labor market transitions. We apply rich administrative data and exploit a difference-indifferences approach. We compare the reference group of 40-44 year olds with constant benefit payout periods to older treatment groups with reduced payout durations. For the latter job exit rates declined, job finding rates increased, the propensity to remain employed increased, and the propensity to remain unemployed declined after the reform. These patterns suggest that the reform of unemployment benefits may be one of the reasons behind the recent incredible rise in old age employment in Germany.

JEL Code: J14, J26

Keywords: labor force participation, employment, unemployment insurance, retirement

${ }^{a}$ Friedrich-Alexander University Erlangen-Nürnberg; Economics Department; Lange Gasse 20; 90403 Nürnberg; Germany

${ }^{\mathrm{b}}$ Corresponding author:

Email: regina.riphahn@fau.de, phone: +49-911-5302-268, fax: -178.

We thank Peter Kuhn, Hendrik Jürges, Simon Trenkle, Arne Uhlendorff, Kamila Cygan-Rehm, Dominique Lemmermann, and participants of the sixth network workshop of the DFG priority program 1764, 2017 Netspar Workshop, 2017 IAB GradAB workshop, seminar at the University of Hamburg, annual meetings of population economics and econometrics groups of the German Economic Association for helpful comments on earlier versions. 


\section{Introduction}

Between 2000 and 2014 the population share of employed older workers (age 55-64) in Germany increased by 53 percent for men and by 110 percent for women. ${ }^{1}$ This development dwarfs the increase in labor force attachment observed among older workers in the United States (Banerjee and Blau 2016) and other countries (Hoffmann and Lemieux 2015). For countries in the grip of demographic ageing, it is important to understand the driving forces behind such a jump in older workers' labor force participation and employment.

This paper addresses the relevance of labor market institutions and their incentive effects for older workers' labor market outcomes. In particular, we use detailed administrative data to investigate the effects of an unemployment insurance (UI) reform on employment transitions of older workers. Understanding the impact of institutional changes on labor force participation choices of older workers is of general interest. The interplay between unemployment benefit provision and employment incentives is an internationally observed phenomenon. Numerous countries attempt to deal with the challenge of aging societies by adjusting the regulation of work, unemployment, and retirement. Therefore, the study of causal reform effects generates important policy-relevant information.

This study connects to two prior contributions: Hoffmann and Lemieux (2015) analyze unemployment in the United States after the Great Recession and compare it to trends in other countries. They investigate the drop in nonemployment among older workers in Germany and argue that labor market reforms are unlikely to "explain a sizable part of the trends in nonemployment" (p. 132). Dlugosz et al. (2014) study the impact of German labor market reforms on older workers' subsequent entries to unemployment. In contrast to Hoffmann and Lemieux (2015), they find substantial reform effects of, e.g., up to 30 percent reductions in

$1 \quad$ Shares computed from Mikrozensus data published by the German Federal Statistical Office; for a discussion see, e.g., Hoffmann and Lemieux (2015). 
unemployment entries. Thus, the relevance of institutional reforms for employment trends of older workers is disputed and we contribute to that debate.

In this paper, we offer a broad and encompassing analysis. We differ from Hoffmann and Lemieux (2015) by focusing first on the effect of one specific reform and second specifically on older workers' labor market flows. We go beyond Dlugosz et al. (2014) by considering a broader set of labor market transitions as outcomes, a more detailed set of institutional features as controls, and by accounting for seasonality and seam effects in monthly transition patterns. $^{2}$

This contributes to several lines of literature: we add to the study of older workers' labor force participation, contribute to the analysis of institutional reform effects, and offer a new perspective on recent labor market developments in Germany. We briefly review the literature in each of these fields:

Older workers' labor force participation (LFP) receives substantial attention due to its immediate fiscal implications (Coile et al. 2014). The trends and determinants of older workers' LFP shifted over recent decades. Peracchi and Welch (1994) refer to developments such as wage dispersion or changes in the industry and occupation mix to explain the falling LFP of older workers in the United States since the 1960s. Schirle (2010) looks at cross country data and finds that, generally, increases in older men's LFP can be explained by increases in the labor market participation of their wives. Blau and Goodstein (2010) conclude that changes in retirement incentives explain between one quarter and one half of the increase in U.S. older male workers' LFP by 2005. Recently, Banerjee and Blau (2016) inspect employment trends in the U.S. through 2010. They find only limited explanatory power in demographics, education, and institutional incentives. We add to this literature by offering evidence on the relevance of institutional reforms in attaining a substantial increase in old-age LFP.

2 Lo et al. (2017) also study the Hartz reform but focus on those aged 45-46, exclusively. 
Second, a large literature studies workers' responses to institutional incentives based on reforms of unemployment and retirement regulations. In an influential early contribution, Hunt (1995) applies survey data to study reforms of the German UI in the 1980s. She concludes that "[t]he large increase in potential duration of ALG [unemployment benefits] provoked a large response, (...)." (p. 118). Fitzenberger and Wilke (2009) study the same reforms with administrative data and confirm strong responses among older unemployed workers. Similarly, Lalive et al. (2006) find that an extension of the potential benefit duration resulted in longer unemployment spells among older workers; they exploited a 1989 reform of the Austrian UI system. In another study on Austria, Inderbitzin et al. (2016) look at the relationship between UI and retirement incentives. Using an extension of unemployment benefits for older workers, they find strong effects on early retirement. The authors suggest that policies aiming at postponing retirement need to consider the full mix of available transfer programs. In a study of shortened unemployment transfers in Slovenia, van Ours and Vodopivec (2006) find strong increases in the exit rate from unemployment. Hairault et al. (2010) adopt a different perspective and address the distance to retirement as a determinant of older workers' labor market behavior. They argue that the returns to job finding vary with a job's potential duration. They also confirm that employment rates of older workers in France increased when incentives to postpone retirement were strengthened. We add to this literature by evaluating the effects of a reform on labor market transitions while accounting for other relevant institutional features.

Third, the good performance of the German labor market attracted international attention (e.g., Hoffmann and Lemieux 2015, Burda and Hunt 2011). Interestingly, the dominant explanations of this development do not assign a central role to labor market reforms: Burda and Hunt (2011) and Dustmann et al. (2014) argue that the labor market reforms implemented between 2003 and 2006 are not of central importance. Instead, they stress different explanations such as the pessimistic hiring behavior of employers prior to the recession, wage moderation, working time accounts, and the governance structure of German labor market 
institutions with decentralized wage setting institutions as the main reason for the strong performance of the German labor market. In contrast, we study the relevance of the institutional framework and its reform for the labor force behavior of older workers. To the extent that

transitions between labor market states (e.g., employment, unemployment, or out-of-the labor force) respond to reforms, prior studies may have underestimated the contribution of these institutions to the overall development.

Based on a difference-in-differences analysis with large samples taken from precise administrative data, we find that the reduction of unemployment benefit payments affected the transition rates of older workers in the expected ways. We compare the reference group of 4044 year olds with constant benefit payout periods to older treatment groups with reduced payout durations. For the latter job exit rates declined, job finding rates increased, the propensity to remain employed increased, and the propensity to remain unemployed declined after the reform. We observe the largest behavioral adjustments among those affected most strongly by the reform. This suggests that reform of unemployment benefits may be one of the reasons behind the incredible rise in old age employment in Germany.

In the next section, we explain the reform and introduce the institutional framework. Based on that, we derive specific hypotheses on adjustments in labor force transitions of older workers. In section three, we introduce our administrative data. We explain our empirical method and identification strategy. Results and robustness tests follow in section four. We conclude in section five.

\section{Institutions and Hypotheses}

We study the role of one institutional reform in the recent increase in older workers' employment, specifically for changes in employment entry and exit. When explaining labor market transitions, it is important "to carefully consider the entire set of welfare programs" 
(Inderbitzin et al. 2016, p. 286). Thus, we discuss the reform of unemployment benefits and other relevant institutions.

Unemployment insurance (UI) 2006 reform: Our attention centers on the reform of unemployment benefits by a law which passed parliament on Dec. 24, 2003 (Hartz IV law). The reform shortened the duration of unemployment benefit payout for workers aged 45 and above by up to 14 months. Table 1 summarizes the changes in transfer durations. The changes vary by the age at which workers enter unemployment: column 2 describes the maximum prereform payout duration, column 3 the post-reform situation, and column 4 the change.

The reform affected workers who became unemployed on or after February 1, 2006. It intended to strengthen older workers' labor market orientation. Job search theory and the empirical literature (see, e.g., Mortensen 1970, Card et al. 2007) suggest that unemployment duration falls with shortened benefit entitlement periods as search intensity increases. In a situation of three mutually exclusive labor force states (employment, unemployment, out-ofthe labor force), we expect that individuals aged 45 and above who became unemployed (U) on or after February 1, 2006 ceteris paribus return to employment (E) faster than their peers who had lost their job earlier (H1: U-E). We expect the effect on exits from unemployment to employment to be strongest among those with the largest reductions in payout periods, i.e., age groups 52-54 and 57 and older (see Table 1). As the reform renders unemployment less attractive, it may reduce workers' reservation wages and propensity to enter unemployment from employment after the reform (H2: E-U). Ceteris paribus and with unchanged incentives to enter the out-of-the labor force state, we expect workers to be more likely to continue employment (H3: E-E), and to be less likely to remain unemployed (H4: U-U) after the reform. In addition to these four hypothesized responses to the reduction in benefit durations, Dlugosz et al. (2014) show substantial evidence of anticipation behavior prior to the reform date. Those older workers who were to lose their jobs on or after February 1, 2006 had an incentive to start an unemployment spell earlier: they benefited from up to 14 additional months 
of transfer if unemployment started prior to the reform cutoff, February 1, 2006. Thus, it is important to account for an anticipatory increase in unemployment entries among older workers prior to February 2006.

Unemployment insurance 2008 reform: In response to strong public opposition to the 2006 reform, the original reductions in payout durations were softened in a second reform. ${ }^{3}$ This 2008 reform law passed parliament in January 2008 and retroactively affected all those unemployed on January 1, 2008 and after. Payout durations increased from 12 to 15 and from 18 to 24 months for selected age groups (see columns 5 and 6 in Table 1). While this reform may have weakened some of the prior adjustments in transition behaviors for the concerned age groups, the net effect continued to be a substantial shortening of payout periods (see column 7 in Table 1). It is unlikely that the 2008 reform generated anticipation effects. ${ }^{4}$ Given the fast adjustment of the 2006 UI reform, it is not possible to evaluate its long run effects.

58 regulation: As an additional change, the '58 regulation' expired at the end of 2007 for those entering unemployment afterwards: the '58 regulation' exempted individuals aged 58 and older from the requirement to search for work which generally is a condition for receiving unemployment benefits. Workers who used the exemption had to retire as soon as they reached full retirement age. The change may have rendered unemployment less attractive for those affected. Workers may have anticipated the termination of the 58 regulation as it was announced already in 2006: those aged 58 and above had an incentive to bring forward an expected entry to unemployment and to enter unemployment prior to January $1,2008 .^{5}$

Retirement insurance: The German retirement system offers various pathways to retirement, which differ in their requirements (e.g., the number of contribution years, retirement

\footnotetext{
$3 \quad$ For an analysis of the 2008 reform on unemployed workers' search effort, see Lichter (2016).

$4 \quad$ The planned regulations were publicly known by Dec. 11, 2007 and benefited all those who continued to be unemployed beyond the end of 2007. In principle, individuals who received job offers after December 11 may have turned them down in expectation of an extension of their unemployment benefits. This might have generated a very brief anticipatory dip in unemployment exits.

$5 \quad$ However, if workers or employers had expected another prolongation (the regulation had been prolonged without interruption since 1985) the anticipation behavior may have been limited.
} 
age, gender, health, or prior unemployment). Table 2 describes five pathways with respect to the minimum age of retirement entry. Due to various reforms, the rules differ by birth cohort. Generally, each pathway allows entry at a full (i.e., normal) and an early retirement age, the latter involving benefit reductions (for a recent description see Engels et al. 2016).

As a first pathway, Table 2 (column A) shows 'retirement due to unemployment' which allows individuals to retire if they were unemployed for at least 52 weeks after reaching age 58.5. ${ }^{6}$ The minimum age for full retirement due to unemployment increased from 60 to 65 for the birth cohorts 1937 to 1941 and after. Since 2006, this pathway to retirement can be used prior to age 65 only via early retirement. Also, the minimum age for early retirement increased from 60 to 63. Thus, in addition to cutbacks in unemployment benefits after 2006 also retirement entry for the unemployed became more restrictive. This may have delayed exits from unemployment into retirement (and indirectly from employment to unemployment) after 2005 for the cohorts 1946 and after.

Column B in Table 2 describes a pathway to retirement that exists only for females: historically, women could enter full retirement at age 60. This entry age was raised and starting with the birth cohorts 1952 this pathway to normal full retirement was abolished altogether. Until the birth cohort of 1951 women could still retire at age 60 via early retirement. Generally, the rising full retirement age for females in the early 2000s should contribute to prolonged employment. In comparison to men the abolition of early retirement at age 60 and the enforcement of age 65 as minimum age for full retirement came much later for women. Therefore, females may respond less strongly to changes in unemployment benefits than men.

Column C in Table 2 shows 'retirement after long term employment', which requires an insurance period of at least 35 years, and column D shows regular old age retirement. These

$6 \quad$ The pathway is also available after partial retirement. Generally, additional requirements must be met. In 2005, 18 percent of all old age retirements occurred via this pathway (DRV 2015). 
pathways remained unchanged during our period of interest (2004-2008). They allow full retirement at age 65 and early retirement for the long term employed at age $63 .^{7}$

Partial retirement subsidies: The German UI subsidized partial retirement schemes where workers work part time over the last (up to) six years of their employment contract. The subsidy was abolished for those starting partial retirement after Dec. 31, 2009. However, this should not affect behavior in the period we are focusing on. ${ }^{8}$

In sum, in testing our hypotheses, we account for anticipation of the 2006 reform, anticipation of the abolition of the 58 regulation, and for changes in retirement entry regulations. In addition, we investigate gender-specific effect heterogeneity.

\section{Data and Method}

\subsection{Data, Sample, and Outcome Measures}

We use administrative data collected by the UI. The Sample of Integrated Labour Market Biographies (SIAB) 7510 provides a two percent random sample of records on all individuals who were in touch with the UI at least once between 1975 and $2010 .{ }^{9}$ This covers about 80 percent of the adult population excluding civil servants and the self-employed. The SIAB data provide employment biographies for more than one million individuals with either a period of employment subject to social security, unemployment benefit receipt, or job search. The data offer various advantages: survey problems such as non-response do not exist, labor force

$7 \quad$ For completeness, column E describes 'retirement for the severely handicapped'. This pathway for those with severe handicaps became more restrictive, as well. Since 2012, there is also a new pathway for the 'very long term employed' with insurance periods of at least 45 years (not shown in Table 2); we do not discuss this as it is outside of our investigation period. In addition, disability retirement allows early retirement under certain conditions, however, its regulation did not change in the period we focus on (see Börsch-Supan and Jürges 2012, Burkhauser et al. 2016).

8 In addition to these institutional reforms, the German labor market underwent additional institutional changes prior to our reform. However, as most of these reforms either were of general nature affecting specific features of the unemployment insurance administration, or took place at a much earlier date, or aimed at the activation of welfare recipients, which are not in the focus of our analyses, we do not discuss them in greater detail (e.g., Eichhorst 2008, Eichhorst and Marx 2011).

$9 \quad$ The data are provided by the Research Data Centre (FDZ) of the German Federal Employment Agency at the Institute for Employment Research (IAB). For details, see vom Berge et al. (2013). 
transitions are observed based on daily reporting, and the sample describes the entire work force subject to the regulations described above.

To test our hypotheses, our data cover March 2004 through December 2007, i.e., the same period before and after the 2006 reform. We consider residents of East and West Germany, aged 40-64 (i.e., birth cohorts 1939-1967), and exclude workers in the construction and mining sectors because they face special unemployment and retirement regulations.

In order to be eligible for the maximum duration of unemployment benefits as described in Table 1, the unemployed must have contributed to the UI for a minimum number of months ("insurance months") (for details see Table A.1). We follow Dlugosz et al. (2014) and concentrate on workers who are eligible for the maximum duration of unemployment benefits as they are fully affected by the reform (for details see Appendix B). Alternatively, we could use (i) the full sample without regard to actual benefit claims. However, in this sample not all individuals are affected by the reform. (ii) Also, we could use a sample of those workers who suffered at least some reduction in their claims as a consequence of the reform, even if they were not eligible to the full transfer duration. We offer robustness tests based on this latter sample in Section 4.3. ${ }^{10}$

We consider individuals' labor force status at the beginning of a month. An individual in employment subject to mandatory social security contributions is coded as employed (state E). We code an individual as unemployed (state $U$ ) if the person receives unemployment benefits (Arbeitslosengeld I), which is our outcome of interest. Individuals who left the labor market are coded to be out-of-the labor force (state O). ${ }^{11}$ Our analysis sample describes 8.02 and 0.43 million person-month observations in employment and unemployment during the 45

10 The samples differ in size. For transitions out of unemployment (employment) we observe about 0.604 (10.065) million person-months in the full sample (i.e., (i)), 0.526 (8.615) in the sample with some benefit reductions (i.e., (ii)), and 0.430 (8.021) in the sample with maximum claims used for the main analysis.

$11 \quad$ For details on the definition of the three labor force status, see Appendix B. 
months period between March 2004 and December 2007 for 226,683 (and 37,358) different individuals starting at least one spell of employment (and unemployment).

We focus on four types of labor market transitions, continued employment E-E, job separations E-U, job findings U-E, and continued unemployment U-U. We code a transition from state A to state B in month $t$ if an individual was in state A on day one of month $t$ and in state B on day one of month $\mathrm{t}+1$. In total, 99.3 and 92.0 percent of all monthly transitions stay in the original states of employment and unemployment, respectively. Starting in employment, 0.26 percent of all monthly transitions are to unemployment (20,855 observations), and 0.41 percent (32,886 observations) to out-of-the labor force or censored states. 2.89 percent of all monthly transitions from unemployment are into employment (12,436 observations) and 5.11 percent (21,988 observations) transit into out-of-the labor force or censoring. ${ }^{12}$

Figures 1.1 and 1.2 depict the seasonality-adjusted development of the four transition rates from employment and unemployment pooled over all age groups. A high share of workers remains in the initial state (see Figure 1.1): the propensity to remain unemployed has declined from about 92 to 89 percent since the end of 2005 whereas the propensity to remain employed was constant and close to 100 percent. Figure 1.2 shows that the job finding rate (U-E) increased since the end of 2005. We also see very little change in job exit rates (E-U): with the exception of an increase at the end of 2005 and a brief decline in January 2006 this transition rate remains at a constant low level. ${ }^{13}$

\subsection{Method}

12 The shares differ when we describe the individual level instead of the person-month. Of all 226,683 individuals starting at least one spell in employment, 78 percent never leave employment, 8.67 percent shift to unemployment with the remaining 13 percent moving to the out-of-the labor force state. Of all 37,358 individuals starting at least one unemployment spell, 14 percent never leave unemployment, 31 percent return to employment and about 55 percent transit to out-of-the labor force. $13 \quad$ Table A.2 in Appendix A shows the age group and gender specific transition rates and sample sizes. 
We are interested in identifying the causal effect of the UI 2006 reform on labor market transitions of older workers. We consider a discrete time duration approach to model transitions between labor market states. Our empirical strategy applies a difference-in-differences estimator where we compare the pre- $(T=0)$ and post-reform $(T=1)$ monthly labor force transitions for age groups affected (treatment group, $G=1$ ) and not affected (control group, $G=0$ ) by the reform. This identifies a causal treatment effect if the transitions of treatment and control groups would have continued to move in tandem without the reform. We address the validity of this parallel path assumption in detail below. Our control group consists of individuals aged 40-44, as older workers are treated by the 2006 reform (see Table 1). Our main estimation equation is:

$$
E[Y \mid T, G, X]=\Lambda(\alpha T+\beta G+\gamma T * G+X \theta)
$$

where $\mathrm{T}$ and $\mathrm{G}$ are time and group indicators, $\mathrm{X}$ contains different sets of control variables, $\Lambda$ is the cumulative distribution function of the binary outcome $(\mathrm{Y})$, and $\alpha, \beta, \gamma$, and $\theta$ are parameters to be estimated.

As our dependent variables indicate rare events - with average transition probabilities of below one percent - estimation results are sensitive to the estimation approach. In such a situation, the predicted outcomes of linear probability models, which impose linearity in marginal effects, can differ substantially from those based on discrete choice models (Greene 2012, p. 729). We apply logit estimations in order to be able to calculate reliable marginal effects. ${ }^{14}$

In order to facilitate the quantitative and qualitative interpretation of the estimation results, we present coefficient estimates with standard errors clustered at the individual level and calculate marginal causal effects. We follow Puhani (2012, see equation 10) and determine

$14 \quad$ Dlugosz et al. (2014) follow the same strategy. Please note, that our data show rare events but not small samples (typically, we have at least 1,000 observations of the rare outcomes). We are therefore not at risk of small sample bias. Nevertheless, we apply estimators appropriate for rare events and small sample sizes to test the robustness of our estimates below. 
the treatment effect of interest $(\tau)$ as the difference between two cross-differences, where $\mathrm{Y}^{0}$ and $\mathrm{Y}^{1}$ are potential outcomes without and with treatment:

$$
\begin{aligned}
\tau(\mathrm{T}=1, \mathrm{G}=1, \mathrm{X}) & =\mathrm{E}\left[\mathrm{Y}^{1} \mid \mathrm{T}=1, \mathrm{G}=1, \mathrm{X}\right]-\mathrm{E}\left[\mathrm{Y}^{0} \mid \mathrm{T}=1, \mathrm{G}=1, \mathrm{X}\right] \\
& =\Lambda(\alpha+\beta+\gamma+\mathrm{X} \theta)-\Lambda(\alpha+\beta+\mathrm{X} \theta) .
\end{aligned}
$$

More specifically, our dependent variable describes whether a given transition between two labor market states is observed for person i between month $\mathrm{m}$ and $\mathrm{m}+1$; we consider indicators of age to represent treatment and control groups (G), and a post-reform indicator (post) as a period indicator $(\mathrm{T})$.

The vector of control variables $\mathrm{X}$ contains two sets of measures (see Table 3). One set (X1) contains general and socio-demographic characteristics: gender, education ${ }^{15}$, federal state of residence, and state-level linear and quadratic time trends, controls for calendar month to capture seasonality, and for calendar year to capture time trends and the business cycle. A second set of controls (X2) accounts for relevant institutions, intervening mechanisms and regulatory changes which we code based on the individuals' year of birth, the period of observation, and the specific regulation. ${ }^{16}$ We estimate the following model:

$$
\mathrm{E}\left[\mathrm{AB}_{\mathrm{i}, \mathrm{m}}\right]=\Lambda\left(\alpha_{0}+\alpha_{1} \text { post }_{i, \mathrm{~m}}+\beta_{1^{\prime}} \text { age }_{\mathrm{i}, \mathrm{m}}+\gamma^{\prime}\left(\text { post }_{\mathrm{i}, \mathrm{m}} * \text { age }_{\mathrm{i}, \mathrm{m}}\right)+\theta_{1}^{\prime} \mathrm{X} 1_{\mathrm{i}, \mathrm{m}}+\theta_{2} \mathrm{X}_{\mathrm{i}, \mathrm{m}}\right)
$$

In a linear model, the coefficient estimate of the interaction of the post-reform indicator with the vector of age measures $(\gamma)$ would yield the causal treatment effect. As we estimate a nonlinear model, we calculate the treatment effect based on equation (2). This allows us to test

\footnotetext{
15 The education information provided in SIAB is at times inconsistent and missing. See Appendix $\mathbf{B}$ for details on how we addressed these issues.

16 When estimating transitions from employment, we account for potential anticipation of the 2006 reform, its interaction with age group indicators and anticipation of the end of the 58 regulation. When estimating transitions from unemployment, we account for whether there are remaining unemployment benefit entitlements and for the duration of past unemployment benefit receipt in the ongoing unemployment spell. With both outcomes, we consider a vector of retirement indicators, which describe current eligibility for early and full retirement and the number of years until eligible for early and full retirement (see Table $\mathbf{3}$ and Appendix B for definitions and Table A.3 for descriptive statistics).
} 
hypotheses H1-H4 regarding the effects of the 2006 reform on labor force transitions accounting for additional relevant institutional features. To help quantify the marginal effects, we additionally present relative marginal effects (RME) which relate the marginal effects to the age-group specific pre-reform mean transition rate for the considered outcome.

\subsection{Parallel Path Assumption}

Our estimations identify causal treatment effects only if the parallel trends assumption holds. Without the reform, the development in labor market transitions for treatment and control groups should have followed parallel trends. We offer two approaches to evaluate the validity of this assumption.

First, we inspect graphically pre-reform trends in outcomes for treatment and control groups. As we consider four different outcome transitions and seven treatment age groups we cannot show all graphs. Figures 2.1-2.4 present the developments over time for the control group (age 40-44) and, exemplarily, for some treatment groups (age groups 45-51, 52-56, and 57-64 combined). ${ }^{17}$ The depicted rates are adjusted for calendar month effects. Each figure illustrates a different outcome. Figure 2.1 shows the propensity to remain employed (E-E transitions) over time. Here, the trend for the oldest age group (57-64) is steeper than that observed for the control group. In contrast, in Figures 2.2-2.4 we do not observe obvious deviations from the parallel path assumption for the three transitions (E-U, U-U, U-E) and age groups considered there.

Second, we offer significance tests of time trend differences. Based on data for the prereform (and, for transitions from E, the pre-anticipation) period, we estimate the following specification using a logit estimator:

$17 \quad$ We combine age groups, to avoid clutter, and because data restrictions require a minimum group size of 20 observations for each data point. We do not reach that minimum for all transitions, age groups, and months. 
$A B_{i, m}=\gamma_{0}+\gamma_{1}$ age $_{i, m}+\gamma_{2} t_{i, m}+\gamma_{3^{\prime}}\left(t_{i, m} *\right.$ age $\left._{i, m}\right)+\gamma_{4^{\prime}} X 1_{i, m}+\gamma_{5^{\prime}} X 2_{i, m}+\varepsilon_{i, m}$.

We interact age indicators for the treated groups with measures of the time trend $(t)$ controlling for the $X 1$ and $X 2$ vectors of covariates. The coefficient vector $\gamma_{2}$ estimates the time trend for the control group; $\gamma_{3}$ indicates whether the time trend differs significantly for the treated age groups. We consider the four relevant transitions and apply linear, quadratic, and cubic specifications of the monthly time trend. If the estimates of $\gamma_{3}$ are jointly statistically significant, the identifying assumption does not hold and we cannot claim to establish causal effects.

Table 4 presents the results of the hypothesis tests for the full sample. We show the pvalues of joint significance tests of $\gamma_{3}$ for the different functional forms for our four transition outcomes. If the test yields statistical significance at the five or one percent level, the p-value is underlined or marked in bold. ${ }^{18}$ Across the four outcomes, we find different patterns. While for the U-U transitions most age-group trends appear to differ significantly from the control group, only a few age-groups appear to follow significantly different time trends compared to the control group of 40-44 year olds for the other three outcomes. For E-E transitions, we find different paths in the 57-59 age group, which confirms our conclusions based on Figure 2.1. For E-U transitions, there is weak evidence for non-parallel paths for age group 63-64 with cubic terms, and with respect to the U-E transitions, only one cubic interaction term yields significant coefficient estimates. These results suggest that our difference-in-differences estimates of U-U transitions may be the result of different pre-reform trends and therefore do not present causal effects. In the other cases, there is no general indication of heterogeneous

18 In addition to the p-values, we inspected the coefficient estimates themselves. In most cases of statistical significance, the pre-reform differences in time trends re-enforced the expected differences between control and treatment groups, e.g., with positive trend differences for 57-59 year olds in the E$\mathrm{E}$ transition and negative trend differences for all age groups in the U-U transition. 
pre-reform outcome trends. We consider this in our interpretation of findings and offer robustness tests controlling for group-wise time trends.

\section{Results and Robustness}

\subsection{Pooled sample}

To determine the causal reform effects on older workers' labor force transitions, we estimate difference-in-differences models on samples of employed and unemployed workers and consider four transition outcomes (E-E, E-U, U-U, and U-E), each coded as a binary indicator. With shortened benefit payout periods we expect increased propensities to stay employed and to enter employment, and reduced propensities to stay unemployed or to enter unemployment for those affected by the reform compared to the reference group of 40-44 year olds who are not affected by the reform.

Table 5 presents coefficient estimates of the relevant parameters when controlling for the treatment indicators, general and socio-demographic control variables and institutional features: the individual coefficients mostly yield the expected sign and small standard errors (clustered at the individual level). ${ }^{19}$ To interpret the estimated effects, we calculated marginal effects and their standard errors based on the delta method (see Table 6). The results generally confirm the patterns of the coefficient estimates in Table 5: column 1 shows positive marginal reform effects on the propensity to stay employed with the largest effects in the oldest groups, i.e., those who suffered the largest decline in benefit duration (see Table 1). We calculated relative marginal effects (RME) dividing the marginal effect by mean pre-reform transition rates in the relevant age group. As an example, the RME for the 63-64 year olds (see column 2) suggests that the reform increased the propensity to stay employed in that age group by 0.34 percent per month.

19 Each reported group of covariates is jointly significant at the 1 percent level for all four outcomes. 
The relative marginal effects are even larger for the other transitions where the baseline mean transition rates are smaller. For example, columns 3 and 4 of Table 6 suggest that for all age groups the reform reduced the propensity to enter unemployment with significant effects of up to 22 percent per month for those aged 57-59. The response patterns match the expected treatment intensity: while the 55-56 year olds lost 8 months in unemployment benefit duration those in the younger (52-54) and older (57-64) age groups lost 14 months and show the expected stronger responses. Dlugosz et al. (2014) estimate similar models for transitions from employment to unemployment only; their age groups and control variables are somewhat different but the results are of comparable magnitude. Surprisingly, we do not obtain statistically significant estimates in the oldest age group and thus cannot reject that the reform did not affect those aged 63 and 64. Columns 5-8 describe reform effects on transitions from unemployment. The reform reduced the propensity to stay unemployed for all age groups (columns 5-6). The job finding rate (see columns 7-8) increased for all age groups after the reform and in part substantially.

In order to illustrate the estimated effect sizes, we first calculate the mean duration in a given state prior to the reform and its reform-induced change (not shown). If, e.g., we consider the 60-62 age group and invert the transition rate, the average period in employment prior to any transition is about 43 months (E-E), the time until a transition to unemployment is almost 15 years (E-U), the duration in unemployment is about 22 months (U-U), and the time until job finding out of unemployment on average about 40 years (U-E). The latter reflects an unusual outcome in this age group. Our RME estimates in Table 6 suggest that uninterrupted stays in E are extended by about 1 day ( 0.08 percent of 43 months), employment prior to job loss is about 33 months longer (a change by 18 percent), time in uninterrupted unemployment spells decreases by about 11 days and the time until finding a job declines from 40 by 9.5 years on average, for this age group. This suggests that the uninterrupted periods in employment and unemployment change very little and that rates of job loss and job finding adjust more strongly. 
This back of the envelope calculation implies that the propensity to leave employment and unemployment for the out-of-the labor force state declined as a result of the reform.

Overall, we cannot reject our four hypotheses regarding the effect of the unemployment benefit reform on labor market transitions of older workers. Thus, the institutional reforms may at least partially be responsible for the substantial increase in the observed employment rates of older workers observed in recent years.

\subsection{Heterogeneity by Gender and Education}

We discussed above that due to the retirement insurance regulations women in contrast to men may still have access to early retirement at age 60 even without prior unemployment spells. Also, women may enter normal retirement prior to age 65, see Table $2 .{ }^{20}$ Females might thus respond less to the unemployment benefit reform of 2006. In order to investigate genderbased heterogeneities, we re-estimated our models of Table 5 separately for male and female subsamples. Tables A.4-A.7 in Appendix A show coefficient estimates and marginal effects by gender. Once we split the samples, a few effects change signs: for example, column 1 of Table A.6 shows a significant negative marginal effect for age group 60-62 which is contrary to expectations, the same holds for the oldest age group of females in column 1 of Table A.7. Overall, we expected larger reform effects for males than for females. However, we do not find consistent evidence of such a pattern. The share of females using the female retirement option in our sample is possibly too small to affect the overall response to the unemployment reform. ${ }^{21}$

In addition, the effect of reduced unemployment benefit duration may differ depending on workers' human capital. Workers with little formal education may be under stronger pressure

\footnotetext{
20 It is important to point out that females must meet several specific requirements regarding their past retirement contributions to be able to enter early and normal retirement prior to males.

21 In separate estimations, we tested whether the reform response among unemployed individuals with dependent children differs from that of those without dependent children. We did not observe significant differences by family status, neither for men nor for women.
} 
to hold a job and they may have more difficulty to find employment than better educated individuals. We can split samples based on educational groups (see Table $\mathbf{3}$ and Table A.3): about 8 percent of the sample holds neither a tertiary nor a vocational degree, about 75 percent hold a vocational degree, and about 15 percent hold a tertiary degree. We estimate our models separately for these subsamples (see Tables A.8-A.13). Generally, we obtain fewer statistically significant marginal age group effects for the smaller subsamples. When we compare the relative marginal effects across education groups, we find significant responses in terms of continued employment across all education groups for those aged 57-59 and the largest relative marginal effects for those with low education. Similarly, the decline in job losses (E-U transitions) is significant and of comparable magnitudes across all education groups. We observe significant changes in U-U transitions for all groups. With respect to job finding rates (U-E transistions) the effects tend to be largest among those with the highest human capital, in particular at age 60 and above (see columns 8 in Tables A.11-A.13). This heterogeneity may be due to better job finding opportunities for the highly educated.

\subsection{Robustness Tests}

So far, we found that the 2006 unemployment benefit reform indeed went along with and potentially caused increased persistence in employment, reduced persistence in unemployment, reduced unemployment entries, and increased unemployment exits. We obtained these results under certain assumptions regarding sample selection, standard error calculations, and the choice of an estimator. In this section, we investigate whether the results are robust to modifying our procedures with respect to these dimensions.

First, we extend our sample of observations. We use not only those workers who can claim the maximum duration of unemployment benefits based on their past labor market career but instead, we now consider all those at least somewhat affected by the reform. As an example, all 45 year olds, who had not yet accumulated 39 insurance months prior to an unemployment 
spell (but, e.g., 32), could not claim 18 (but e.g. 16) months of unemployment benefit prereform (see Table A.1). Therefore, they did not experience the full reform-induced decline from 18 to 12 months benefit payout. Table A.14 shows the coefficient estimates and Table 7 the marginal effects and the relative marginal effects for the extended sample. A comparison of the results in Table 6 with those in Table 7 confirms a remarkable robustness of our main findings: the patterns of signs, significance, and marginal effects are very similar when we use the extended sample. Regarding transitions from employment effect sizes increased and with respect to transitions from unemployment effect sizes slightly decreased. The most substantial difference appears to be the relative marginal effect in the transition from unemployment to employment for the oldest age group (see column 8). Here the extended sample suggests a large increase in the job finding rate for the newly added workers with weaker ties to the labor market. Generally, the results in Table 7 strongly confirm the positive effect of the reform on labor market attachment, increased job finding and reduced job exit rates.

We perform a second test to evaluate a selectivity dimension in our data. While we explicitly control for anticipation behavior prior to the reform, we never account for the potential mechanical effect such anticipated transitions might yield on post-reform transition. As an example, the propensity to leave unemployment for employment may be subdued early after February 2006 if numerous workers just moved the unemployment entry forward to get it accomplished prior to February 1. In March and April, this group may be less motivated to find a job compared to the random person before the reform. Similarly, if many unemployment entries have been brought forward to early 2006, in the aggregate there may be a reduced risk of job loss afterwards. In order to test whether such mechanisms affect our findings, we apply a "donut-estimator" and re-estimated the model after omitting observations from periods right after the reform. In Table 8, we show the estimated marginal effects after omitting the months 
February - July 2006 (for coefficient estimates see Table A.15). ${ }^{22}$ Our estimates are generally highly robust. However, among E-E transitions the effect for 60-62 year olds loses statistical significance, similarly for the E-U transitions of 55-56 year olds. The results for the other transitions are confirmed in terms of magnitude and significance. ${ }^{23}$

We consider a third test dealing with an issue of sample selection. Given the reduced unemployment benefit payout periods, our observations of monthly transitions from unemployment are selected differently pre- and post-reform. Before the reform, we observe individuals with potentially up to 32 months of ongoing unemployment spells. After the reform, the longest period of potential benefit receipt drops to 18 months. We repeat our estimations of the transitions from unemployment after limiting our sample in both periods to those observations in unemployment for less than 1 year. The sample size drops from about 430 to about 261 thousand observations. We show the marginal and relative marginal effect results in Table 9 (for coefficient estimates see Table A.16). Our results are generally robust to these selectivity controls with generally slightly reduced effect sizes. Only the marginal effects for the transitions in the oldest age group change signs.

A fourth and related aspect refers to the specific incentives that derive from the discrete jumps in the duration of benefit receipt at certain ages. These jumps generate incentives for 'almost unemployed' workers close to the age cutoffs of age 44, 46, 51, 56 pre-reform and at 54 post-reform to postpone unemployment entry. Since these incentives differ before and after the reform, they may bias our estimates. We repeat our estimations omitting individuals of the relevant ages and show the marginal and relative marginal effect results for transitions from employment in Table 10 (for coefficient estimates see Table A.17). Now all marginal effects

\footnotetext{
22 We also estimated the model when omitting only February - May 2006. There, we observe even smaller changes in effects compared to Table 6.

23 Given the lack of parallel pre-reform time trends for the U-U transitions (see Table 4), we estimated a model accounting for age-groups specific trends (results not yet presented). The results of Table 6 were robust to this modification. Therefore, the difference between the correlation and a causal effect may not be very large.
} 
for E-E transitions are positive. The results for E-U transitions are also highly robust even though we lost about one quarter of the observations: the effect for the youngest age group becomes significant, those for older age groups (55-56) lose precision. The magnitude of the RME is robust to this change in sampling.

In duration models, the omission of controls for duration dependence may cause biased estimation results. In our models for transitions from unemployment, we account for the duration of the ongoing spell. In our fifth test, we added controls for the duration of the ongoing spell in models for transitions from E, as well. We show the marginal effect results in Table 11 (for coefficient estimates see Table A.18). While some estimates lose statistical significance the overall results are confirmed.

In our sixth test, we change the way standard errors are computed. While we allowed for clusters at the individual level so far, we now cluster at the cohort and calendar year level because that is the level at which the reform affects workers. We show the estimated marginal effects in in Table 12 and the coefficient estimates in Table A.19. Clustering the standard errors at a more conservative level merely affects the statistical significance of the E-E transitions. Overall, the other marginal effects and significance levels did not change. Therefore, we conclude that our results are not due to unaccounted correlation patterns of unobservable error terms.

Finally, we evaluate to what extent the results are robust to the choice of an estimator. We first replaced the logit by a probit and then by a complementary log-log model, which is a common choice in estimations of dichotomous dependent variables with very unbalanced outcomes. We present the coefficient estimates in Tables A.20 and A.21 and the marginal effects in Tables 13 and 14. Comparing the results in Tables 6 on the one hand and in Tables 13 and 14 confirms that the marginal effects are highly robust to the choice of an estimator.

\section{Conclusions}


When we observe vast changes in labor force participation, it is important to understand the underlying processes. This is of particular and international interest if the observed change is one that is relevant and desired for many labor markets. We study a potential determinant of an incredible rise in older workers' labor force participation in Germany, where since 2000 the population share of employed older workers (age 55-64) increased by 53 percent for men and by 110 percent for women.

As the literature disagrees on the relevance of the institutional framework, we investigate whether labor market reforms affect older workers' transitions between labor force states. We focus on a reform of unemployment benefit duration, implemented in February 2006 that shortened unemployment benefit payout by between 6 and 14 months for workers above age 44. Based on a difference-in-differences estimator we compare the change in labor force transitions of workers affected and not affected by the reform.

We consider a setting with three labor force states (employment, unemployment, outof-the labor force). Based on a search theory rationale, we expect that shortened unemployment benefit payout reduces the propensity to enter unemployment (E-U) and to leave employment (E-E); also it should increase the propensity to take up employment (U-E) and to leave unemployment (U-U). We test these hypotheses while considering a number of institutional developments; we account for potential anticipation behavior, which has been found in prior studies (Dlugosz et al. 2014). Moreover, we carefully control for changes in retirement regulations that might affect labor market choices. Our precise administrative data offer large sample sizes.

We find that the reduction of unemployment benefit payments affected the transition rates of older workers in the expected ways. Compared to a reference group of 40-44 year olds for whom benefit payout did not change, we find that after the reform job exit rates declined, job finding rates increased, the propensity to stay in employment increased and the propensity to stay in unemployment declined. We observe the largest behavioral adjustments among those 
affected most strongly by the reform. We predict that on average, e.g., 60-62 year olds stayed employed more than 2.7 years longer prior to entering unemployment. This group reduced the expected time in unemployment prior to re-entering employment by almost one quarter. Overall, we cannot interpret all of our findings as causal effects. This is particularly the case for $\mathrm{U}-\mathrm{U}$ transitions and for certain older age groups in E-E transitions. Nevertheless, the patterns we find suggest that the reform of unemployment benefits may be one of the reasons behind the recent incredible rise in old age employment in Germany.

We compare the effects for subsamples separated by gender and education. We test the robustness of our results to different specifications of the estimation model, the sample selection mechanisms, and the estimators. In all cases, our results are corroborated.

We confirm the relevance of institutional reforms for labor force participation choices of older workers. There is strong evidence that institutions matter and can have substantial effects on the employment behavior of older workers. This is important news for many countries with ailing retirement systems. 


\section{Bibliography}

Banerjee, Sudipto and David Blau, 2016, Employment Trends by Age in the United States - Why are older workers different?, Journal of Human Resources 51(1), 163-199.

BGBL.I (Bundesgesetzblatt), various years, www.bgbl.de [last access: Nov. 29, 2016]

Blau, David M. and Ryan M. Goodstein, 2010, Can Social Security Explain Trends in Labor Force Participation of Older Men in the United States?, Journal of Human Resources 45(2), 328-363.

Börsch-Supan, Axel and Hendrik Jürges, 2012, Disability, pension reform, and early retirement in Germany, in: Wise, David .A. (ed.) Social security programs and retirement around the world: historical trends in mortality and health, employment, and disability insurance participation, pp. 277-300.

Burda, Michael and Jennifer Hunt, 2011, What Explains the German Labor Market Miracle in the Great Recession? Brookings Papers on Economic Activity 42(1), 273-335.

Burkhauser, Richard V., Mary C. Daly, and Nicolas R. Ziebarth, 2016, Protecting working-age people with disabilities: experiences of four industrialized nations, Journal for Labour Market Research 49(4), 367-386.

Card, David, Raj Chetty, and Andrea Weber, 2007, Cash-on-hand and competing models of intertemporal behavior: new evidence from the labor market, Quarterly Journal of Economics 122(4), 1511-1560.

Coile, Courtney, Kevin S. Milligan, and David A. Wise, 2014, Social Security Programs and Retirement around the World: Disability Insurance Programs and Retirement - Introduction and Summary, NBER Working Paper 20120, Cambridge, Mass.

DRV (Deutsche Rentenversicherung), 2015, Rentenversicherung in Zeitreihen, Oktober 2015, Berlin.

Dietz, Martin and Ulrich Walwei, 2011, Germany - No Country for Old Workers?, Zeitschrift für Arbeitsmarktforschung (Journal for Labour Market Research) 44(4), 363-376.

Dlugosz, Stephan, Gesine Stephan, and Ralf A. Wilke, 2014, Fixing the Leak: Unemployment Incidence before and after a Major Reform of Unemployment Benefits in Germany, German Economic Review 15(3), 329-352.

Dustmann, Christian, Bernd Fitzenberger, Uta Schönberg, and Alexandra Spitz-Oener, 2014, From Sick Man of Europe to Economic Superstar: Germany's Resurgent Economy, Journal of Economic Perspectives 28(1), 167-188.

Eichhorst, Werner, 2008, Die Agenda 2010 und die Grundsicherung für Arbeitsuchende, Vierteljahreshefte zur Wirtschaftsforschung 77(1), 38-50.

Eichhorst, Werner and Paul Marx, 2011, Reforming German Labour Market Institutions, Journal of European Social Policy 21(1), 73-87.

Engels, Barbara, Johannes Geyer, and Peter Haan, 2016, Pension incentives and early retirement, DIW Discussion Paper No. 1617, DIW Berlin.

Fitzenberger, Bernd and Ralf A. Wilke, 2009, Unemployment Durations in West Germany Before and After the Reform of the Unemployment Compensation System during the 1980s, German Economic Review 11(3), 336-366.

Greene, William H., 2012, Econometric Analysis, 7th edition, Pearson Education Limited, Harlow, England.

Hairault, Jean-Olivier, Francois Langot, and Thepthida Sopraseuth, 2010, Distance to Retirement and Older Workers' Employment: The Case for Delaying the Retirement Age, Journal of the European Economic Association 8(5), 1034-1076.

Hoffmann, Florian and Thomas Lemieux, 2015, Unemployment in the Great Recession: A Comparison of Germany, Canada, and the United States, Journal of Labor Economics 34(1, pt. 2), S95-139.

Hunt, Jennifer, 1995, The Effect of the Unemployment Compensation on Unemployment Duration in Germany, Journal of Labor Economics 13(1), 88-120.

Inderbitzin, Lukas, Stefan Staubli, and Josef Zweimüller, 2016, Extended Unemployment Benefits and Early Retirement: Program Complementarity and Program Substitution, American Economic Journal: Economic Policy 8(1), 253-288.

Jung, Philip and Moritz Kuhn, 2014, Labour Market Institutions and Workers Flows: Comparing Germany and the US, The Economic Journal 124, 1317-1342. 
Lalive, Rafael, Jan van Ours, and Josef Zweimüller, 2006, How Changes in Financial Incentives Affect the Duration of Unemployment, Review of Economic Studies 73(4), 1009-1038.

Lichter, Andreas, 2016, Benefit Duration and Job Search Effort: Evidence from a Natural Experiment, IZA Discussion Paper No. 10264, IZA Bonn.

Lo, Simon M. S., Gesine Stephan, and Ralf A. Wilke, 2017, Competing Risks Copula Models for Unemployment Duration: An Application to a German Hartz Reform, Journal of Econometric Methods 6(1), 1-20.

Mortensen, Dale, 1970, Job Search, the Duration of Unemployment and the Phillips Curve, American Economic Review 60(5), 847-862.

Oschmiansky, Frank, 2013, Arbeitslosenversicherung, URL: http://www.bpb.de/politik/innenpolitik/ arbeitsmarktpolitik/155254/arbeitslosenversicherung (last access Febr. 22, 2017)

Peracchi, Franco and Finis Welch, 1994, Trends in Labor Force Transitions of Older Men and Women, Journal of Labor Economics 12(2), 210-242.

Puhani, Patrick A., 2012, The Treatment Effect, the Cross Difference, and the Interaction Term in Nonlinear "Difference-in-Difference" Models, Economics Letters 115(1), 85-87.

Schirle, Tammy, 2008, Why have the labor force participation rates of older men increased since the mid-1990s?, Journal of Labor Economics 26(4), 549-594.

Schmieder, Johannes F., Till von Wachter, and Stefan Bender, 2012, The Effects of Extended Unemployment Insurance over the Business Cycle: Evidence from Regression Discontinuity Estimates of 20 Years, Quarterly Journal of Economics 127(2), 701-752.

van Ours, Jan C. and Milan Vodopivec, 2006, How Shortening the Potential Duration of Unemployment Benefits Affects the Duration of Unemployment: Evidence from a Natural Experiment, Journal of Labor Economics 24(2), 351-378.

vom Berge, Philipp, Marion König, and Stefan Seth, 2013, Stichprobe der Integrierten Arbeitsmarktbiographien (SIAB) 1975-2010, FDZ Datenreport 01/2013, IAB Nürnberg. 
Table 1 Maximum duration of unemployment benefit receipt (in months) by age and period

\begin{tabular}{|c|c|c|c|c|c|c|}
\hline Age & $\begin{array}{c}2 \\
\text { Pre-Reform } \\
\text { until 1/06 }\end{array}$ & $\begin{array}{c}3 \\
\text { Post-Reform } \\
2006 \\
\text { 2/06-12/07 }\end{array}$ & $\begin{array}{c}4 \\
\text { Change } \\
\text { in months } \\
3-2\end{array}$ & $\begin{array}{c}5 \\
\text { Post-Reform } \\
2008 \\
\text { since } 1 / 08\end{array}$ & $\begin{array}{c}6 \\
\text { Change } \\
\text { in months } \\
5-3\end{array}$ & $\begin{array}{c}7 \\
\text { Total change } \\
\text { in months } \\
5-2\end{array}$ \\
\hline$<45$ & 12 & 12 & 0 & 12 & 0 & 0 \\
\hline $45-46$ & 18 & 12 & -6 & 12 & 0 & -6 \\
\hline $47-49$ & 22 & 12 & -10 & 12 & 0 & -10 \\
\hline $50-51$ & 22 & 12 & -10 & 15 & 3 & -7 \\
\hline $52-54$ & 26 & 12 & -14 & 15 & 3 & -11 \\
\hline 55-56 & 26 & 18 & -8 & 18 & 0 & -8 \\
\hline 57 & 32 & 18 & -14 & 18 & 0 & -14 \\
\hline$>57$ & 32 & 18 & -14 & 24 & 6 & -8 \\
\hline
\end{tabular}

Note: The cut in durations as of February 2006 affected those unemployed since February 1, 2006. The prolongation of unemployment benefit durations as of January 2008 affected those entering unemployment on or after January 1, 2008 and aged 50 or 58 at that time, or those still receiving unemployment benefits from a prior entry to unemployment on January 1, 2008 and aged at least 50 or 58 at that time.

Source: BGBL.I, 1997, p. 627; BGBL.I, 2003, p. 3004; BGBL.I, 2008, p. 681 
Table 2 Age at Retirement by Birth Cohort and Pathway

\begin{tabular}{|c|c|c|c|c|c|c|c|c|c|c|}
\hline \multirow{3}{*}{$\begin{array}{l}\text { Birth } \\
\text { Cohort }\end{array}$} & \multicolumn{2}{|c|}{$\mathrm{A}$} & \multicolumn{2}{|c|}{ B } & \multirow{2}{*}{\multicolumn{2}{|c|}{$\longrightarrow$ C }} & \multirow{2}{*}{\multicolumn{2}{|c|}{$\overline{\text { Reoular old }}^{\mathrm{D}} \overline{\overline{\text { tirement }}}$}} & \multicolumn{2}{|c|}{$\mathrm{E}$} \\
\hline & \multicolumn{2}{|c|}{ Retirement due to unemployment } & \multicolumn{2}{|c|}{ Retirement for women } & & Ret. after long term employment & & & \multicolumn{2}{|c|}{$\overline{\text { Severely handicapped retirement }}$} \\
\hline & Full Age (Yr.) & Early Age (Yr.) & Full Age (Yr.) & Early Age (Yr.) & Full Age (Yr.) & Early Age (Yr.) & Full Age (Yr.) & Early Age & (Yr.) Full Age (Yr.) & Early Age (Yr.) \\
\hline 1934 & $60(1994)$ & n.a. & $60(1994)$ & n.a. & $63(1997)$ & n.a. & $65(1999)$ & n.a. & $60(1994)$ & n.a. \\
\hline 1935 & 60 (1995) & n.a. & 60 (1995) & n.a. & rising to 64 (1999) & 63 (1998) & $65(2000)$ & n.a. & 60 (1995) & n.a. \\
\hline 1936 & 60 (1996) & n.a. & 60 (1996) & n.a. & rising to 65 (2001) & 63 (1999) & $65(2001)$ & n.a. & 60 (1996) & n.a. \\
\hline 1937 & rising to 61 (1998) & 60 (1997) & 60 (1997) & n.a. & $65(2002)$ & $63(2000)$ & $65(2002)$ & n.a. & 60 (1997) & n.a. \\
\hline 1938 & rising to 62 (2000) & 60 (1998) & 60 (1998) & n.a. & 65 (2003) & $63(2001)$ & 65 (2003) & n.a. & 60 (1998) & n.a. \\
\hline 1939 & rising to 63 (2002) & 60 (1999) & 60 (1999) & n.a. & 65 (2004) & $63(2002)$ & $65(2004)$ & n.a. & 60 (1999) & n.a. \\
\hline 1940 & rising to 64 (2004) & $60(2000)$ & rising to 61 (2001) & $60(2000)$ & 65 (2005) & $63(2003)$ & 65 (2005) & n.a. & * rising to 61 (2001) & $60(2000)$ \\
\hline 1941 & rising to 65 (2006) & $60(2001)$ & rising to 62 (2003) & $60(2001)$ & 65 (2006) & $63(2004)$ & 65 (2006) & n.a. & * rising to 62 (2003) & $60(2001)$ \\
\hline 1942 & $65(2007)$ & $60(2002)$ & rising to 63 (2005) & 60 (2002) & 65 (2007) & 63 (2005) & 65 (2007) & n.a. & * rising to 63 (2005) & $60(2002)$ \\
\hline 1943 & 65 (2008) & $60(2003)$ & rising to 64 (2007) & $60(2003)$ & 65 (2008) & $63(2006)$ & 65 (2008) & n.a. & * 63 (2006) & $60(2003)$ \\
\hline 1944 & 65 (2009) & $60(2004)$ & rising to 65 (2009) & $60(2004)$ & 65 (2009) & 63 (2007) & 65 (2009) & n.a. & * 63 (2007) & $60(2004)$ \\
\hline 1945 & $65(2010)$ & 60 (2005) & $65(2010)$ & 60 (2005) & 65 (2010) & 63 (2008) & 65 (2010) & n.a. & * 63 (2008) & 60 (2005) \\
\hline 1946 & 65 (2011) & rising to 61 (2007) & 65 (2011) & 60 (2006) & 65 (2011) & 63 (2009) & 65 (2011) & n.a. & * 63 (2009) & $60(2006)$ \\
\hline 1947 & 65 (2012) & rising to 62 (2009) & 65 (2012) & 60 (2007) & 65 (2012) & 63 (2010) & rising to $651 \mathrm{~m}$. & n.a. & * 63 (2010) & 60 (2007) \\
\hline 1948 & 65 (2013) & rising to 63 (2011) & 65 (2013) & 60 (2008) & 65 (2013) & $63(2011)$ & rising to $652 \mathrm{~m}$. & n.a. & * 63 (2011) & 60 (2008) \\
\hline 1949 & 65 (2014) & 63 (2012) & 65 (2014) & 60 (2009) & rising to $653 \mathrm{~m}$. & $63(2012)$ & rising to $653 \mathrm{~m}$. & n.a. & * 63 (2012) & 60 (2009) \\
\hline 1950 & 65 (2015) & 63 (2013) & 65 (2015) & 60 (2010) & rising to $654 \mathrm{~m}$. & 63 (2013) & rising to $654 \mathrm{~m}$. & n.a. & * 63 (2013) & 60 (2010) \\
\hline 1951 & $65(2016)$ & $63(2014)$ & 65 (2016) & $60(2011)$ & rising to $655 \mathrm{~m}$. & 63 (2014) & rising to $655 \mathrm{~m}$. & n.a. & $63(2014)$ & $60(2011)$ \\
\hline 1952 & $\overline{\text { retirement pathw }}$ & vay terminated & retirement pathn & $\overline{\text { ay terminated }}$ & rising to $656 \mathrm{~m}$. & 63 (2015) & rising to $656 \mathrm{~m}$. & n.a. & rising to $631 \mathrm{~m}$. & rising to $601 \mathrm{~m}$. \\
\hline 1953 & & & & & rising to $657 \mathrm{~m}$. & 63 (2016) & rising to $657 \mathrm{~m}$. & n.a. & rising to $632 \mathrm{~m}$. & rising to $602 \mathrm{~m}$. \\
\hline 1954 & & & & & rising to $658 \mathrm{~m}$. & 63 (2017) & rising to $658 \mathrm{~m}$. & n.a. & rising to $633 \mathrm{~m}$. & rising to $603 \mathrm{~m}$. \\
\hline 1955 & & & & & rising to $659 \mathrm{~m}$. & 63 (2018) & rising to $659 \mathrm{~m}$. & n.a. & rising to $634 \mathrm{~m}$. & rising to $604 \mathrm{~m}$. \\
\hline 1956 & & & & & rising to $6510 \mathrm{~m}$. & 63 (2019) & rising to $6510 \mathrm{~m}$. & n.a. & rising to $635 \mathrm{~m}$. & rising to $605 \mathrm{~m}$. \\
\hline 1957 & & & & & rising to $6511 \mathrm{~m}$. & $63(2020)$ & rising to $6511 \mathrm{~m}$. & n.a. & rising to $636 \mathrm{~m}$. & rising to $606 \mathrm{~m}$. \\
\hline 1958 & & & & & rising to 66 (2024) & $63(2021)$ & rising to 66 & n.a. & rising to $637 \mathrm{~m}$. & rising to $607 \mathrm{~m}$. \\
\hline 1959 & & & & & rising to $662 \mathrm{~m}$. & 63 (2022) & rising to $662 \mathrm{~m}$. & n.a. & rising to $638 \mathrm{~m}$. & rising to $608 \mathrm{~m}$. \\
\hline 1960 & & & & & rising to $664 \mathrm{~m}$. & 63 (2023) & rising to $664 \mathrm{~m}$. & n.a. & rising to $639 \mathrm{~m}$. & rising to $609 \mathrm{~m}$. \\
\hline 1961 & & & & & rising to $666 \mathrm{~m}$. & 63 (2024) & rising to $666 \mathrm{~m}$. & n.a. & rising to $6310 \mathrm{~m}$. & rising to $6010 \mathrm{~m}$. \\
\hline 1962 & & & & & rising to $668 \mathrm{~m}$. & 63 (2025) & rising to $668 \mathrm{~m}$. & n.a. & rising to $6311 \mathrm{~m}$. & rising to $6011 \mathrm{~m}$. \\
\hline 1963 & & & & & rising to $6610 \mathrm{~m}$. & $63(2026)$ & rising to $6610 \mathrm{~m}$. & n.a. & rising to 64 & rising to 61 \\
\hline 1964 & & & & & rising to 67 (2031) & $63(2027)$ & rising to 67 & n.a. & rising to $641 \mathrm{~m}$. & rising to $611 \mathrm{~m}$. \\
\hline
\end{tabular}


Table 3 List of explanatory variables (for further details see Appendix B)

\begin{tabular}{|c|c|}
\hline Variable & Description \\
\hline \multicolumn{2}{|l|}{ Treatment indicators } \\
\hline Post-reform & Indicator for transition after the 2006 reform \\
\hline \multicolumn{2}{|l|}{ 40-44 years old } \\
\hline \multicolumn{2}{|l|}{ 45-46 years old } \\
\hline \multicolumn{2}{|l|}{ 47-51 years old } \\
\hline \multicolumn{2}{|r|}{ Indicator for the age group (ref. $=40-44$ years old) } \\
\hline $55-56$ years old & Indicator for the age group (ret. $=40-44$ years old) \\
\hline \multicolumn{2}{|l|}{$57-59$ years old } \\
\hline \multicolumn{2}{|l|}{ 60-62 years old } \\
\hline \multicolumn{2}{|l|}{ 63-64 years old } \\
\hline Post-reform x 40-44 years old, ..., & Interaction: post-reform and age group indicators (ref. $=40-44$ years \\
\hline Post-reform x 63-64 years old & old) \\
\hline \multicolumn{2}{|c|}{ General and socio-demographic characteristics (X1) } \\
\hline \multicolumn{2}{|l|}{ Gender, education, state of residence } \\
\hline Female & Indicator variable for the gender \\
\hline \multicolumn{2}{|l|}{ No univ. degree \& no voc. training* } \\
\hline Vocational training* & Indicator variables for the education groups (ref. = no university \\
\hline Univ. degree/techn. College* & degree \& no voc. training) \\
\hline \multicolumn{2}{|l|}{ Education missing* } \\
\hline Schleswig-Holstein, ..., Sachsen-Anhalt & Indicator for residential state (ref. = NRW) \\
\hline \multicolumn{2}{|c|}{ Linear and quadratic trends $x$ state , month and year effects } \\
\hline Year x Schleswig-Holstein, ..., & Interaction: calendar year (coded $1,2, \ldots$ ) and residential state (ref. = \\
\hline Year x Sachsen-Anhalt & $\mathrm{NRW})$ \\
\hline $\begin{array}{l}\text { Year^2 x Schleswig-Holstein, ..., } \\
\text { Year^2 x Sachsen-Anhalt }\end{array}$ & Interaction: calendar year squared and residential state (ref. = NRW) \\
\hline January, ..., December & Indicator for month of transition (ref. =January) \\
\hline $2004, \ldots, 2007$ & Indicator for calendar year of transition (ref. =2004) \\
\hline \multicolumn{2}{|l|}{ Institutional indicators (X2) } \\
\hline \multicolumn{2}{|l|}{ Retirement controls } \\
\hline Early retirement* & $\begin{array}{l}\text { Indicator that transition to early retirement with benefit reductions is } \\
\text { possible at time of transition }\end{array}$ \\
\hline Full retirement* & $\begin{array}{l}\text { Indicator that transition to full retirement without benefit reductions is } \\
\text { possible at time of transition }\end{array}$ \\
\hline Distance to early retirement* & Variable for the years until eligibility for early retirement \\
\hline Distance to full retirement* & Variable for the years until eligibility for full retirement \\
\hline \multicolumn{2}{|l|}{ Anticipation controls } \\
\hline Antic* & $\begin{array}{l}\text { Indicator for transitions from E: transition takes place in the } \\
\text { anticipation period of } 2006 \text { reform: 09/2005 - 01/2006 }\end{array}$ \\
\hline $\begin{array}{l}\text { Antic x } 40-44 \text { years old, ..., } \\
\text { Antic x 63-64 years old }\end{array}$ & $\begin{array}{l}\text { Interaction for transitions from E: anticipation period and age group } \\
\text { (ref. }=40-44 \text { years old) }\end{array}$ \\
\hline reg58* & $\begin{array}{l}\text { Indicator for transitions from E: transition possibly affected by end of } \\
58 \text { regulation (cohorts 1944-49 in period 10/2007-12/2007) }\end{array}$ \\
\hline \multicolumn{2}{|l|}{ Unemployment benefits controls } \\
\hline Remaining entitlement of UB* & $\begin{array}{l}\text { Indicator for transitions from } \mathrm{U} \text { : individual has unemployment benefit } \\
\text { entitlements left at time of transition }\end{array}$ \\
\hline $\begin{array}{l}\text { Days of past UB receipt in current } U \\
\text { period* }\end{array}$ & $\begin{array}{l}\text { Variable for transitions from U: number of days individual has } \\
\text { received unemployment benefits in current } U \text { period at time of } \\
\text { transition }\end{array}$ \\
\hline
\end{tabular}


Table 4 Tests for parallel trends: pooled sample

\begin{tabular}{|c|c|c|c|c|c|c|c|c|c|c|c|c|}
\hline & \multicolumn{3}{|c|}{ E-E transitions } & \multicolumn{3}{|c|}{ E-U transitions } & \multicolumn{3}{|c|}{ U-U transitions } & \multicolumn{3}{|c|}{ U-E transitions } \\
\hline & linear & quadratic & cubic & linear & quadratic & cubic & linear & quadratic & cubic & linear & quadratic & cubic \\
\hline 45-46 years old & 0.0819 & 0.2126 & 0.3551 & 0.1821 & 0.2769 & 0.3386 & 0.6764 & 0.0933 & 0.1106 & 0.5577 & 0.0484 & 0.0720 \\
\hline 47-51 years old & 0.3141 & 0.5271 & 0.7359 & 0.5647 & 0.7895 & 0.8961 & $\underline{0.0141}$ & $\underline{0.0386}$ & 0.0856 & 0.1007 & 0.2340 & 0.3655 \\
\hline 52-54 years old & 0.0934 & 0.1143 & 0.0773 & 0.1397 & 0.3103 & 0.3976 & 0.0005 & 0.0005 & 0.0002 & 0.2325 & 0.3441 & $\underline{0.0297}$ \\
\hline 55-56 years old & 0.1462 & 0.0574 & 0.0517 & 0.0540 & 0.0900 & 0.1803 & 0.0000 & 0.0000 & 0.0000 & 0.2935 & 0.5623 & 0.3591 \\
\hline 57-59 years old & 0.0050 & 0.0004 & 0.0000 & 0.8615 & 0.8288 & 0.5203 & 0.0000 & 0.0000 & 0.0000 & 0.4566 & 0.2045 & 0.0946 \\
\hline 60-62 years old & 0.6480 & 0.9074 & 0.0770 & 0.0564 & 0.1227 & 0.1406 & 0.0000 & 0.0000 & 0.0000 & 0.7032 & 0.8986 & 0.9538 \\
\hline 63-64 years old & 0.9892 & 0.0002 & 0.0001 & 0.2352 & 0.4747 & 0.0071 & 0.0013 & 0.0058 & 0.0042 & 0.8204 & 0.9731 & 0.8346 \\
\hline \multicolumn{13}{|l|}{ Controls: } \\
\hline $\begin{array}{l}\text { Age, gender, education, state } \\
\text { of residence }\end{array}$ & \multicolumn{3}{|c|}{ yes } & \multicolumn{3}{|c|}{ yes } & \multicolumn{3}{|c|}{ yes } & \multicolumn{3}{|c|}{ yes } \\
\hline Month effects & \multicolumn{3}{|c|}{ yes } & \multicolumn{3}{|c|}{ yes } & \multicolumn{3}{|c|}{ yes } & \multicolumn{3}{|c|}{ yes } \\
\hline Retirement controls & \multicolumn{3}{|c|}{ yes } & \multicolumn{3}{|c|}{ yes } & \multicolumn{3}{|c|}{ yes } & \multicolumn{3}{|c|}{ yes } \\
\hline Unemployment benefit controls & \multicolumn{3}{|c|}{ no } & \multicolumn{3}{|c|}{ no } & \multicolumn{3}{|c|}{ yes } & \multicolumn{3}{|c|}{ yes } \\
\hline
\end{tabular}

Note: Standard errors are clustered at the individual level. Estimation period: Transitions from E=03/2004 -08/2005; Transitions from U=03/2004 -01/2006. Table shows p-values for the tests of joint significance of the coefficient for age specific time trends $\left(\beta_{3}\right.$ in equation 2$)$. For a list and definition of control variables, see Table 3.

Source: SIAB 7510 and own calculations. 
Table 5 Logit coefficients of the reform effects on labour market transitions controlling for retirement, anticipation, and employment benefits: pooled sample

\begin{tabular}{|c|c|c|c|c|}
\hline & $\begin{array}{l}\text { E-E transitions } \\
\text { (1) }\end{array}$ & $\begin{array}{l}\text { E-U transitions } \\
\text { (2) }\end{array}$ & $\begin{array}{l}\text { U-U transitions } \\
\text { (3) }\end{array}$ & $\begin{array}{l}\text { U-E transitions } \\
\text { (4) }\end{array}$ \\
\hline Post-reform & $\begin{array}{l}-0.3508 * * * \\
(0.0528)\end{array}$ & $\begin{array}{l}0.6853 * * * \\
(0.0841)\end{array}$ & $\begin{array}{r}-0.0484 \\
(0.0364)\end{array}$ & $\begin{array}{l}-0.1133 * * * \\
(0.0434)\end{array}$ \\
\hline Post-reform x 45-46 years old & $\begin{array}{r}-0.0216 \\
(0.0404)\end{array}$ & $\begin{array}{r}-0.0204 \\
(0.0555)\end{array}$ & $\begin{array}{l}-0.2958 * * * \\
(0.0616)\end{array}$ & $\begin{array}{l}0.1558 * * \\
(0.0655)\end{array}$ \\
\hline Post-reform x 47-51 years old & $\begin{array}{r}0.0183 \\
(0.0305)\end{array}$ & $\begin{array}{l}-0.1229 * * * \\
(0.0425)\end{array}$ & $\begin{array}{l}-0.6186 * * * \\
(0.0515)\end{array}$ & $\begin{array}{l}0.1008 * \\
(0.0538)\end{array}$ \\
\hline Post-reform x 52-54 years old & $\begin{array}{r}0.0590 \\
(0.0367)\end{array}$ & $\begin{array}{l}-0.1229 * * \\
(0.0530)\end{array}$ & $\begin{array}{l}-0.9303 * * * \\
(0.0625)\end{array}$ & $\begin{array}{l}0.2950 * * * \\
(0.0686)\end{array}$ \\
\hline Post-reform x 55-56 years old & $\begin{array}{r}0.0038 \\
(0.0410)\end{array}$ & $\begin{array}{r}-0.0671 \\
(0.0597)\end{array}$ & $\begin{array}{l}-0.7713 * * * \\
(0.0703)\end{array}$ & $\begin{array}{l}0.2209 * * \\
(0.0864)\end{array}$ \\
\hline Post-reform x 57-59 years old & $\begin{array}{l}0.2038 * * * \\
(0.0358)\end{array}$ & $\begin{array}{l}-0.3613 * * * \\
(0.0558)\end{array}$ & $\begin{array}{l}-0.6814 * * * \\
(0.0683)\end{array}$ & $\begin{array}{l}0.5397 * * * \\
(0.1038)\end{array}$ \\
\hline Post-reform x 60-62 years old & $\begin{array}{r}0.0397 \\
(0.0313)\end{array}$ & $\begin{array}{l}-0.2808 * * * \\
(0.0626)\end{array}$ & $\begin{array}{l}-0.6280 * * * \\
(0.0817)\end{array}$ & $\begin{array}{l}0.6047 * * * \\
(0.1773)\end{array}$ \\
\hline Post-reform x 63-64 years old & $\begin{array}{l}0.0710 * \\
(0.0391)\end{array}$ & $\begin{array}{r}-0.0766 \\
(0.1286)\end{array}$ & $\begin{array}{l}-0.4915 * * * \\
(0.1052)\end{array}$ & $\begin{array}{r}0.0127 \\
(0.4538)\end{array}$ \\
\hline Controls: & & & & \\
\hline $\begin{array}{l}\text { Age, gender, education, state of } \\
\text { residence }\end{array}$ & yes & yes & yes & yes \\
\hline $\begin{array}{l}\text { Linear and quadratic trends x state, } \\
\text { month and year effects }\end{array}$ & yes & yes & yes & yes \\
\hline Retirement controls & yes & yes & yes & yes \\
\hline Anticipation controls & yes & yes & no & no \\
\hline Unemployment benefit controls & no & no & yes & yes \\
\hline $\mathrm{N}$ & \multicolumn{2}{|c|}{$8,020,998$} & \multicolumn{2}{|c|}{430,301} \\
\hline Mean & 0.9933 & 0.0026 & 0.9200 & 0.0289 \\
\hline
\end{tabular}

Note: Standard errors are clustered at the individual level. ***: $\mathrm{p}<1 \%$; $*$ : $\mathrm{p}<5 \%$; $*$ : $<10 \%$. Pre-reform period: Transitions from E=03/2004 -08/2005; Transitions from U=03/2004 01/2006. Anticipation period: Transitions from E=09/2005 - 01/2006. Post-reform period: 02/2006 - 12/2007. For a list and definition of control variables, see Table 3.

Source: SIAB 7510 and own calculations. 
Table 6

Logit estimates of marginal effects (ME) and relative marginal effects (RME) of the reform on labor market transitions controlling for retirement, anticipation and unemployment benefits: pooled sample

\begin{tabular}{|c|c|c|c|c|c|c|c|c|}
\hline & \multicolumn{2}{|c|}{ E-E transitions } & \multicolumn{2}{|c|}{ E-U transitions } & \multicolumn{2}{|c|}{ U-U transitions } & \multicolumn{2}{|c|}{ U-E transitions } \\
\hline & $\begin{array}{l}\mathrm{ME} \\
(1) \\
\end{array}$ & $\begin{array}{l}\text { RME } \\
(2) \\
\end{array}$ & $\begin{array}{c}\mathrm{ME} \\
(3) \\
\end{array}$ & $\begin{array}{l}\text { RME } \\
(4) \\
\end{array}$ & $\begin{array}{l}\mathrm{ME} \\
(5) \\
\end{array}$ & $\begin{array}{l}\text { RME } \\
(6) \\
\end{array}$ & $\begin{array}{l}\mathrm{ME} \\
(7) \\
\end{array}$ & $\begin{array}{l}\text { RME } \\
(8) \\
\end{array}$ \\
\hline 45-46 years old & $\begin{array}{r}-0.00009 \\
(0.00010)\end{array}$ & $-0.01 \%$ & $\begin{array}{r}-0.00004 \\
(0.00007)\end{array}$ & $-1.65 \%$ & $\begin{array}{l}-0.02899 * * * \\
(0.00449)\end{array}$ & $-3.29 \%$ & $\begin{array}{l}0.01059 * * * \\
(0.00329)\end{array}$ & $19.79 \%$ \\
\hline 47-51 years old & $\begin{array}{r}0.00008 \\
(0.00007)\end{array}$ & $0.01 \%$ & $\begin{array}{l}-0.00025 * * * \\
(0.00005)\end{array}$ & $-9.96 \%$ & $\begin{array}{l}-0.04723 * * * \\
(0.00282)\end{array}$ & $-5.20 \%$ & $\begin{array}{l}0.00548 * * * \\
(0.00208)\end{array}$ & $13.64 \%$ \\
\hline 52-54 years old & $\begin{array}{l}0.00028 * * * \\
(0.00010)\end{array}$ & $0.03 \%$ & $\begin{array}{l}-0.00026 * * * \\
(0.00006)\end{array}$ & $-9.29 \%$ & $\begin{array}{l}-0.05905 * * * \\
(0.00339)\end{array}$ & $-6.37 \%$ & $\begin{array}{l}0.01264 * * * \\
(0.00250)\end{array}$ & $46.88 \%$ \\
\hline 55-56 years old & $\begin{array}{r}0.00002 \\
(0.00014)\end{array}$ & $0.00 \%$ & $\begin{array}{l}-0.00016 \text { * } \\
(0.00009)\end{array}$ & $-4.98 \%$ & $\begin{array}{l}-0.03614 * * * \\
(0.00317)\end{array}$ & $-3.85 \%$ & $\begin{array}{l}0.00641 * * * \\
(0.00220)\end{array}$ & $36.05 \%$ \\
\hline 57-59 years old & $\begin{array}{l}0.00161 * * * \\
(0.00015)\end{array}$ & $0.16 \%$ & $\begin{array}{l}-0.00103 * * * \\
(0.00008)\end{array}$ & $-22.29 \%$ & $\begin{array}{l}-0.02232 * * * \\
(0.00214)\end{array}$ & $-2.33 \%$ & $\begin{array}{l}0.00650 * * * \\
(0.00131)\end{array}$ & $105.52 \%$ \\
\hline 60-62 years old & $\begin{array}{l}0.00080 * * \\
(0.00034)\end{array}$ & $0.08 \%$ & $\begin{array}{l}-0.00103 * * * \\
(0.00013)\end{array}$ & $-18.39 \%$ & $\begin{array}{l}-0.01581 * * * \\
(0.00208)\end{array}$ & $-1.66 \%$ & $\begin{array}{l}0.00271 * * * \\
(0.00091)\end{array}$ & $130.92 \%$ \\
\hline 63-64 years old & $\begin{array}{l}0.00318 * * * \\
(0.00088)\end{array}$ & $0.34 \%$ & $\begin{array}{r}-0.00023 \\
(0.00022)\end{array}$ & $-6.15 \%$ & $\begin{array}{l}-0.01637 * * * \\
(0.00369)\end{array}$ & $-1.77 \%$ & $\begin{array}{r}0.00003 \\
(0.00096)\end{array}$ & $2.14 \%$ \\
\hline
\end{tabular}

\section{Controls:}

Age, gender, education, state of residence

Linear and quadratic trends x state, month

and year effects

Retirement controls

Anticipation controls

Unemployment benefit controls

$\begin{array}{ll}\text { yes } & \text { yes } \\ \text { yes } & \text { yes } \\ \text { yes } & \text { yes } \\ \text { yes } & \text { yes } \\ \text { no } & \text { no }\end{array}$

yes
yes
yes
yes
no

$8,020,998$

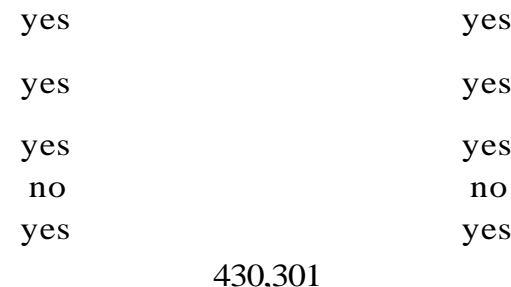

Note: Standard errors are clustered at the individual level. ***: $\mathrm{p}<1 \%$; **: $\mathrm{p}<5 \%$; * $\mathrm{p}<10 \%$. RME are calculated as the relation of the age-specific marginal effect and the mean probability of the transition in the pre-reform period for the specific age group. Pre-reform period: Transitions from $E=03 / 2004$-08/2005; Transitions from U=03/2004 - 01/2006. Anticipation period: Transitions from E=09/2005 - 01/2006. Post-reform period: 02/2006 - 12/2007. Estimations include main reform effect "post-reform". For a list and definition of control variables, see Table 3.

Source: SIAB 7510 and own calculations. 
Table 7

Logit estimates of marginal effects (ME) and relative marginal effects (RME) of the reform on labor market transitions controlling for retirement, anticipation and unemployment benefits: extended pooled sample

\begin{tabular}{|c|c|c|c|c|c|c|c|c|}
\hline & \multicolumn{2}{|c|}{ E-E transitions } & \multicolumn{2}{|c|}{ E-U transitions } & \multicolumn{2}{|c|}{ U-U transitions } & \multicolumn{2}{|c|}{ U-E transitions } \\
\hline & $\begin{array}{l}\text { ME } \\
(1) \\
\end{array}$ & $\begin{array}{l}\text { RME } \\
(2) \\
\end{array}$ & $\begin{array}{l}\text { ME } \\
(3) \\
\end{array}$ & $\begin{array}{c}\mathrm{RME} \\
(4) \\
\end{array}$ & $\begin{array}{l}\mathrm{ME} \\
(5) \\
\end{array}$ & $\begin{array}{c}\mathrm{RME} \\
(6) \\
\end{array}$ & $\begin{array}{l}\mathrm{ME} \\
(7) \\
\end{array}$ & $\begin{array}{c}\mathrm{RME} \\
(8) \\
\end{array}$ \\
\hline 45-46 years old & $\begin{array}{r}0.00007 \\
(0.00010)\end{array}$ & $0.01 \%$ & $\begin{array}{r}-0.00012 \\
(0.00007)\end{array}$ & $-4.36 \%$ & $\begin{array}{l}-0.02616 * * * \\
(0.00417)\end{array}$ & $-2.99 \%$ & $\begin{array}{l}0.00764 * \\
(0.00309)\end{array}$ & $13.15 \%$ \\
\hline 47-51 years old & $\begin{array}{l}0.00024 * * * \\
(0.00007)\end{array}$ & $0.02 \%$ & $\begin{array}{l}-0.00032 * * * \\
(0.00005)\end{array}$ & $-10.26 \%$ & $\begin{array}{l}-0.04080 * * * \\
(0.00260)\end{array}$ & $-4.53 \%$ & $\begin{array}{r}0.00362 \\
(0.00193)\end{array}$ & $7.91 \%$ \\
\hline 52-54 years old & $\begin{array}{l}0.00064 * * * \\
(0.00010)\end{array}$ & $0.06 \%$ & $\begin{array}{l}-0.00051 * * * \\
(0.00007)\end{array}$ & $-14.01 \%$ & $\begin{array}{l}-0.05194 * * * \\
(0.00299)\end{array}$ & $-5.65 \%$ & $\begin{array}{l}0.00997 * * * \\
(0.00229)\end{array}$ & $30.03 \%$ \\
\hline 55-56 years old & $\begin{array}{r}0.00023 \\
(0.00014)\end{array}$ & $0.02 \%$ & $\begin{array}{l}-0.00035 * * * \\
(0.00009)\end{array}$ & $-10.14 \%$ & $\begin{array}{l}-0.03415 * * * \\
(0.00308)\end{array}$ & $-3.66 \%$ & $\begin{array}{c}0.00459 * \\
(0.00221)\end{array}$ & $20.69 \%$ \\
\hline 57-59 years old & $\begin{array}{l}0.00199 * * * \\
(0.00015)\end{array}$ & $0.20 \%$ & $\begin{array}{l}-0.00118 * * * \\
(0.00009)\end{array}$ & $-25.54 \%$ & $\begin{array}{l}-0.02297 * * * \\
(0.00200)\end{array}$ & $-2.41 \%$ & $\begin{array}{l}0.00849 * * * \\
(0.00140)\end{array}$ & $100.59 \%$ \\
\hline 60-62 years old & $\begin{array}{l}0.00089 * * \\
(0.00033)\end{array}$ & $0.09 \%$ & $\begin{array}{l}-0.00091 * * * \\
(0.00014)\end{array}$ & $-17.30 \%$ & $\begin{array}{l}-0.01516 * * * \\
(0.00197)\end{array}$ & $-1.59 \%$ & $\begin{array}{l}0.00427 * * * \\
(0.00106)\end{array}$ & $141.39 \%$ \\
\hline 63-64 years old & $\begin{array}{l}0.00393 * * * \\
(0.00085)\end{array}$ & $0.41 \%$ & $\begin{array}{r}-0.00038 \\
(0.00023)\end{array}$ & $-10.11 \%$ & $\begin{array}{l}-0.01374 * * * \\
(0.00373)\end{array}$ & $-1.49 \%$ & $\begin{array}{r}0.00280 \\
(0.00163)\end{array}$ & $155.56 \%$ \\
\hline \multicolumn{9}{|l|}{ Controls: } \\
\hline Age, gender, education, state of residence & yes & & yes & & yes & & yes & \\
\hline $\begin{array}{l}\text { Linear and quadratic trends x state, month } \\
\text { and year effects }\end{array}$ & yes & & yes & & yes & & yes & \\
\hline Retirement controls & yes & & yes & & yes & & yes & \\
\hline Anticipation controls & yes & & yes & & no & & no & \\
\hline Unemployment benefit controls & no & & no & & yes & & yes & \\
\hline $\mathrm{N}$ & \multicolumn{4}{|c|}{$8,615,029$} & \multicolumn{4}{|c|}{525,562} \\
\hline
\end{tabular}

Note: Standard errors are clustered at the individual level. ***: $\mathrm{p}<1 \%$; **: $<<5$; *: $\mathrm{p}<10 \%$. RME are calculated as the relation of the age-specific marginal effect and the mean probability of the transition in the pre-reform period for the specific age group. Pre-reform period: Transitions from $E=03 / 2004$-08/2005; Transitions from U=03/2004 - 01/2006. Anticipation period: Transitions from E=09/2005 - 01/2006. Post-reform period: 02/2006 -12/2007. Estimations include main reform effect "post-reform". For a list and definition of control variables, see Table 3. For a definition of the sample, see 3.1 .

Source: SIAB 7510 and own calculations. 
Table 8

Logit estimates of marginal effects (ME) and relative marginal effects (RME) of the reform on labor market transitions controlling for retirement, anticipation and unemployment benefits: pooled sample without February-July 2006

\begin{tabular}{|c|c|c|c|c|c|c|c|c|}
\hline & \multicolumn{2}{|c|}{ E-E transitions } & \multicolumn{2}{|c|}{ E-U transitions } & \multicolumn{2}{|c|}{ U-U transitions } & \multicolumn{2}{|c|}{ U-E transitions } \\
\hline & $\begin{array}{c}\mathrm{ME} \\
(1) \\
\end{array}$ & $\begin{array}{c}\text { RME } \\
(2) \\
\end{array}$ & $\begin{array}{c}\text { ME } \\
\text { (3) } \\
\end{array}$ & $\begin{array}{c}\mathrm{RME} \\
(4) \\
\end{array}$ & $\begin{array}{c}\text { ME } \\
(5) \\
\end{array}$ & $\begin{array}{c}\text { RME } \\
(6) \\
\end{array}$ & $\begin{array}{c}\mathrm{ME} \\
(7) \\
\end{array}$ & $\begin{array}{c}\text { RME } \\
(8) \\
\end{array}$ \\
\hline 45-46 years old & $\begin{array}{r}0.00003 \\
(0.00012)\end{array}$ & $0.00 \%$ & $\begin{array}{r}-0.00007 \\
(0.00008)\end{array}$ & $-2.90 \%$ & $\begin{array}{l}-0.02911 * * * \\
(0.00480)\end{array}$ & $-3.30 \%$ & $\begin{array}{l}0.00983 * * * \\
(0.0035)\end{array}$ & $18.49 \%$ \\
\hline 47-51 years old & $\begin{array}{r}0.00010 \\
(0.00008)\end{array}$ & $0.01 \%$ & $\begin{array}{l}-0.00023 * * * \\
(0.00005)\end{array}$ & $-9.39 \%$ & $\begin{array}{l}-0.04748 * * * \\
(0.00297)\end{array}$ & $-5.22 \%$ & $\begin{array}{l}0.00505 * * \\
(0.00221)\end{array}$ & $12.77 \%$ \\
\hline 52-54 years old & $\begin{array}{l}0.00030 * * * \\
(0.00011)\end{array}$ & $0.03 \%$ & $\begin{array}{l}-0.00026 * * * \\
(0.00007)\end{array}$ & $-10.16 \%$ & $\begin{array}{l}-0.06090 * * * \\
(0.00362)\end{array}$ & $-6.57 \%$ & $\begin{array}{l}0.01201 * * * \\
(0.00266)\end{array}$ & $44.33 \%$ \\
\hline 55-56 years old & $\begin{array}{r}-0.00003 \\
(0.00016)\end{array}$ & $0.00 \%$ & $\begin{array}{r}-0.00010 \\
(0.00010)\end{array}$ & $-3.53 \%$ & $\begin{array}{l}-0.03631 * * * \\
(0.00329)\end{array}$ & $-3.87 \%$ & $\begin{array}{l}0.00525 * * * \\
(0.00227)\end{array}$ & $29.68 \%$ \\
\hline 57-59 years old & $\begin{array}{l}0.00187 * * * \\
(0.00016)\end{array}$ & $0.19 \%$ & $\begin{array}{l}-0.00085 * * * \\
(0.00010)\end{array}$ & $-23.22 \%$ & $\begin{array}{l}-0.02261 * * * \\
(0.00224)\end{array}$ & $-2.37 \%$ & $\begin{array}{l}0.00666 * * * \\
(0.00135)\end{array}$ & $114.43 \%$ \\
\hline 60-62 years old & $\begin{array}{r}0.00052 \\
(0.00040)\end{array}$ & $0.05 \%$ & $\begin{array}{l}-0.00080 * * * \\
(0.00016)\end{array}$ & $-17.62 \%$ & $\begin{array}{l}-0.01687 * * * \\
(0.00219)\end{array}$ & $-1.77 \%$ & $\begin{array}{l}0.00257 * * * \\
(0.00096)\end{array}$ & $117.35 \%$ \\
\hline 63-64 years old & $\begin{array}{l}0.00371 * * * \\
(0.00100)\end{array}$ & $0.39 \%$ & $\begin{array}{r}0.00004 \\
(0.00025)\end{array}$ & $1.23 \%$ & $\begin{array}{l}-0.01532 * * * \\
(0.00384)\end{array}$ & $-1.66 \%$ & $\begin{array}{l}0.000047 \\
(0.00102)\end{array}$ & $3.92 \%$ \\
\hline
\end{tabular}

\section{Controls:}

Age, gender, education, state of residence

Linear and quadratic trends x state, month and year effects

Retirement controls

Anticipation controls

Unemployment benefit controls $\mathrm{N}$

$\begin{array}{cc} & \\ \text { yes } & \text { yes } \\ \text { yes } & \text { yes } \\ \text { yes } & \text { yes } \\ \text { yes } & \text { yes } \\ \text { no } & \text { no }\end{array}$

$6,980,023$

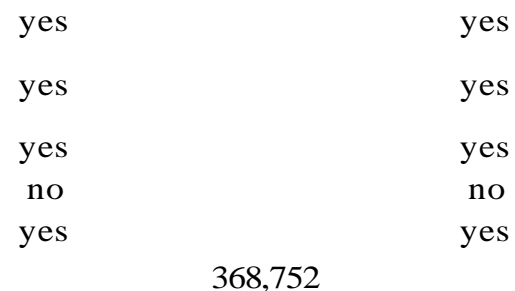

Note: Standard errors are clustered at the individual level. ***: $\mathrm{p}<1 \%$; **: $\mathrm{p}<5 \%$; * $\mathrm{p}<10 \%$. RME are calculated as the relation of the age-specific marginal effect and the mean probability of the transition in the pre-reform period for the specific age group. Pre-reform period: Transitions from E=03/2004 -08/2005; Transitions from U=03/2004 - 01/2006. Anticipation period: Transitions from E=09/2005 - 01/2006. Post-reform period: 02/2006 - 12/2007. Estimations include main reform effect "post-reform". For a list and definition of control variables, see Table 3.

Source: SIAB 7510 and own calculations. 
Table 9 Logit estimates of marginal effects (ME) and relative marginal effects (RME) of the reform on labor market transitions controlling for retirement, anticipation and unemployment benefits: transitions from unemployment for those unemployed less than 1 year

\begin{tabular}{lcccc}
\hline & \multicolumn{2}{c}{ U-U transitions } & \multicolumn{2}{c}{ U-E transitions } \\
& $\mathrm{ME}$ & $\mathrm{RME}$ & $\mathrm{ME}$ & $\mathrm{RME}$ \\
& $(5)$ & $(6)$ & $(7)$ & $(8)$ \\
\hline \multirow{2}{*}{ 45-46 years old } & $-0.02594 * * *$ & $-2.92 \%$ & $0.01008 * * *$ & $18.66 \%$ \\
& $(0.00414)$ & & $(0.00328)$ & \\
47-51 years old & $-0.04166 * * *$ & $-4.48 \%$ & $0.00551 * * *$ & $12.63 \%$ \\
& $(0.00270)$ & & $(0.00209)$ & \\
52-54 years old & $-0.04948 * * *$ & $-5.23 \%$ & $0.01332 * * *$ & $44.11 \%$ \\
& $(0.00328)$ & & $(0.00256)$ & \\
$55-56$ years old & $-0.02822 * * *$ & $-2.93 \%$ & $0.00708 * * *$ & $34.44 \%$ \\
& $(0.00329)$ & & $(0.00234)$ & \\
57-59 years old & $-0.01741 * * *$ & $-1.78 \%$ & $0.00646 * * *$ & $95.28 \%$ \\
& $(0.00230)$ & & $(0.00143)$ & \\
60-62 years old & $-0.00705 * * *$ & $-0.72 \%$ & $0.00177 *$ & $55.31 \%$ \\
& $(0.00209)$ & & $(0.00101)$ & \\
63-64 years old & $0.00665 *$ & $0.69 \%$ & -0.00155 & $-53.08 \%$ \\
\end{tabular}

\section{Controls:}

\begin{tabular}{lcc} 
Age, gender, education, state of residence & yes & yes \\
Linear and quadratic trends x state, month & yes & yes \\
and year effects & yes & yes \\
Retirement controls & no & no \\
Anticipation controls & yes & yes \\
Unemployment benefit controls & & 261,589 \\
$\mathrm{~N}$ & & \\
\hline
\end{tabular}

Note: Standard errors are clustered at the individual level. ***: $\mathrm{p}<1 \%$; **: $\mathrm{p}<5 \%$; $: \mathrm{p}<10 \%$. RME are calculated as the relation of the age-specific marginal effect and the mean probability of the transition in the pre-reform period for the specific age group. Pre-reform period: Transitions from $\mathrm{E}=03 / 2004$-08/2005; Transitions from U=03/2004 - 01/2006. Anticipation period: Transitions from E=09/2005 - 01/2006. Post-reform period: 02/2006 -12/2007. Estimations include main reform effect "post-reform”. For a list and definition of control variables, see Table 3.

Source: SIAB 7510 and own calculations. 
Logit estimates of marginal effects (ME) and relative marginal effects (RME) of the reform on labor market transitions controlling for retirement, anticipation and unemployment benefits: transitions from employment omitting observations aged 45, 47, 52, 55, and 57

\begin{tabular}{lccccc}
\hline & \multicolumn{2}{c}{ E-E transitions } & \multicolumn{2}{c}{ E-U transitions } \\
& $\mathrm{ME}$ & $\mathrm{RME}$ & $\mathrm{ME}$ & $\mathrm{RME}$ \\
& $(5)$ & $(6)$ & $(7)$ & $(8)$ \\
\hline 46 years old & 0.00014 & $0.01 \%$ & $-0.00024 * *$ & $-9.64 \%$ \\
& $(0.00014)$ & & $(0.00010)$ & \\
48-51 years old & 0.00009 & $0.01 \%$ & $-0.00025 * * *$ & $-10.00 \%$ \\
& $(0.00008)$ & & $(0.00005)$ & \\
53-54 years old & $0.00067 * * *$ & $0.07 \%$ & $-0.00044 * * *$ & $-16.36 \%$ \\
& $(0.00012)$ & & $(0.00008)$ & \\
56 years old & 0.00001 & $0.00 \%$ & -0.00016 & $-5.57 \%$ \\
& $(0.00019)$ & & $(0.00012)$ & \\
58-59 years old & $0.00206 * * *$ & $0.21 \%$ & $-0.00087 * * *$ & $-22.96 \%$ \\
& $(0.00020)$ & & $(0.00012)$ & \\
60-62 years old & $0.00071 * *$ & $0.07 \%$ & $-0.00098 * * *$ & $-21.59 \%$ \\
& $(0.00034)$ & & $(0.00013)$ & \\
63-64 years old & $0.00293 * * *$ & $0.31 \%$ & -0.00022 & $-6.75 \%$ \\
\hline
\end{tabular}

\section{Controls:}

\begin{tabular}{lcc} 
Age, gender, education, state of residence & yes & yes \\
Linear and quadratic trends x state , month & yes & yes \\
and year effects & yes & yes \\
Retirement controls & no & no \\
Anticipation controls & yes & yes \\
Unemployment benefit controls & & $6,161,997$ \\
$\mathrm{~N}$ & & \\
\hline
\end{tabular}

Note: Standard errors are clustered at the individual level. ***: $\mathrm{p}<1 \%$; **: $\mathrm{p}<5 \%$; * $\mathrm{p}<10 \%$. RME are calculated as the relation of the age-specific marginal effect and the mean probability of the transition in the pre-reform period for the specific age group. Pre-reform period: Transitions from $\mathrm{E}=03 / 2004$-08/2005; Transitions from U=03/2004 - 01/2006. Anticipation period: Transitions from E=09/2005 - 01/2006. Post-reform period: 02/2006 -12/2007. Estimations include main reform effect “post-reform”. For a list and definition of control variables, see Table 3.

Source: SIAB 7510 and own calculations. 
Table 11

Logit estimates of marginal effects (ME) and relative marginal effects (RME) of the reform on labor market transitions controlling for the duration in the ongoing employment spell

\begin{tabular}{|c|c|c|c|c|}
\hline & \multicolumn{2}{|c|}{ E-E transitions } & \multicolumn{2}{|c|}{ E-U transitions } \\
\hline & $\begin{array}{c}\text { ME } \\
\text { (5) }\end{array}$ & $\begin{array}{c}\text { RME } \\
\text { (6) }\end{array}$ & $\begin{array}{c}\text { ME } \\
\text { (7) }\end{array}$ & $\begin{array}{c}\text { RME } \\
\text { (8) }\end{array}$ \\
\hline 45-46 years old & $\begin{array}{r}-0.00012 \\
(0.00010)\end{array}$ & $-0.01 \%$ & $\begin{array}{r}-0.00000 \\
(0.00007)\end{array}$ & $0.00 \%$ \\
\hline 47-51 years old & $\begin{array}{r}0.00003 \\
(0.00007)\end{array}$ & $0.00 \%$ & $\begin{array}{l}-0.00019 * * * \\
(0.00005)\end{array}$ & $-7.57 \%$ \\
\hline 52-54 years old & $\begin{array}{l}0.00021 * * \\
(0.00010)\end{array}$ & $0.02 \%$ & $\begin{array}{l}-0.00024 * * * \\
(0.00006)\end{array}$ & $-8.57 \%$ \\
\hline 55-56 years old & $\begin{array}{r}-0.00004 \\
(0.00014)\end{array}$ & $0.00 \%$ & $\begin{array}{r}-0.00016 \\
(0.00009)\end{array}$ & $-4.98 \%$ \\
\hline 57-59 years old & $\begin{array}{l}0.00148 \text { *** } \\
(0.00015)\end{array}$ & $0.15 \%$ & $\begin{array}{l}-0.00102 * * * \\
(0.00008)\end{array}$ & $-22.08 \%$ \\
\hline 60-62 years old & $\begin{array}{r}0.00037 \\
(0.00034)\end{array}$ & $0.04 \%$ & $\begin{array}{l}-0.00090 * * * \\
(0.00014)\end{array}$ & $-16.07 \%$ \\
\hline 63-64 years old & $\begin{array}{r}0.00097 \\
(0.00091)\end{array}$ & $0.10 \%$ & $\begin{array}{r}0.00007 \\
(0.00022)\end{array}$ & $1.87 \%$ \\
\hline
\end{tabular}

\section{Controls:}

\begin{tabular}{lcc} 
Age, gender, education, state of residence & yes & yes \\
Linear and quadratic trends x state , month & yes & yes \\
and year effects & yes & yes \\
Retirement controls & no & no \\
Anticipation controls & yes & yes \\
Unemployment benefit controls & & $8,020,998$ \\
$\mathrm{~N}$ & & \\
\hline
\end{tabular}

Note: Standard errors are clustered at the individual level. ***: $\mathrm{p}<1 \%$; **: $\mathrm{p}<5 \%$; * $\mathrm{p}<10 \%$. RME are calculated as the relation of the age-specific marginal effect and the mean probability of the transition in the pre-reform period for the specific age group. Pre-reform period: Transitions from $\mathrm{E}=03 / 2004$-08/2005; Transitions from U=03/2004 - 01/2006. Anticipation period: Transitions from E=09/2005 - 01/2006. Post-reform period: 02/2006 -12/2007. Estimations include main reform effect "post-reform”. For a list and definition of control variables, see Table 3.

Source: SIAB 7510 and own calculations. 
Table 12 Logit estimates of marginal effects (ME) and relative marginal effects (RME) of the reform on labor market transitions controlling for retirement, anticipation and unemployment benefits: pooled sample with different clustered standard errors

\begin{tabular}{|c|c|c|c|c|c|c|c|c|}
\hline & \multicolumn{2}{|c|}{ E-E transitions } & \multicolumn{2}{|c|}{ E-U transitions } & \multicolumn{2}{|c|}{ U-U transitions } & \multicolumn{2}{|c|}{ U-E transitions } \\
\hline & $\begin{array}{c}\mathrm{ME} \\
(1)\end{array}$ & $\begin{array}{c}\text { RME } \\
(2)\end{array}$ & $\begin{array}{c}\mathrm{ME} \\
\text { (3) }\end{array}$ & $\begin{array}{c}\mathrm{RME} \\
(4)\end{array}$ & $\begin{array}{c}\mathrm{ME} \\
\text { (5) }\end{array}$ & $\begin{array}{c}\text { RME } \\
(6)\end{array}$ & $\begin{array}{c}\mathrm{ME} \\
(7)\end{array}$ & $\begin{array}{c}\mathrm{RME} \\
\text { (8) }\end{array}$ \\
\hline 45-46 years old & $\begin{array}{l}-0.00008 \\
(0.00009)\end{array}$ & $-0.01 \%$ & $\begin{array}{c}-0.00005 \\
(0.00007)\end{array}$ & $-2.07 \%$ & $\begin{array}{l}-0.02907 * * * \\
(0.00869)\end{array}$ & $-3.30 \%$ & $\begin{array}{l}0.01067 * * * \\
(0.00325)\end{array}$ & $19.94 \%$ \\
\hline 47-51 years old & $\begin{array}{r}0.00013 \\
(0.00008)\end{array}$ & $0.01 \%$ & $\begin{array}{l}-0.00029 * * * \\
(0.00008)\end{array}$ & $-11.55 \%$ & $\begin{array}{l}-0.04769 * * * \\
(0.00438)\end{array}$ & $-5.25 \%$ & $\begin{array}{l}0.00612 * * * \\
(0.00191)\end{array}$ & $15.24 \%$ \\
\hline 52-54 years old & $\begin{array}{r}0.00005 \\
(0.00008)\end{array}$ & $0.01 \%$ & $\begin{array}{l}-0.00016 * * \\
(0.00007)\end{array}$ & $-5.71 \%$ & $\begin{array}{l}-0.05791 * * * \\
(0.00693)\end{array}$ & $-6.25 \%$ & $\begin{array}{l}0.01096 * * * \\
(0.00286)\end{array}$ & $40.65 \%$ \\
\hline 55-56 years old & $\begin{array}{r}-0.00009 \\
(0.00013)\end{array}$ & $-0.01 \%$ & $\begin{array}{r}-0.00012 \\
(0.00008)\end{array}$ & $-3.74 \%$ & $\begin{array}{l}-0.03579 * * * \\
(0.00487)\end{array}$ & $-3.81 \%$ & $\begin{array}{l}0.00596 * * * \\
(0.00169)\end{array}$ & $33.52 \%$ \\
\hline 57-59 years old & $\begin{array}{r}0.00125 \\
(0.00138)\end{array}$ & $0.13 \%$ & $\begin{array}{l}-0.00089 * * * \\
(0.00015)\end{array}$ & $-19.26 \%$ & $\begin{array}{l}-0.02181 * * * \\
(0.00380)\end{array}$ & $-2.28 \%$ & $\begin{array}{l}0.00620 * * * \\
(0.00137)\end{array}$ & $100.65 \%$ \\
\hline 60-62 years old & $\begin{array}{r}0.00079 \\
(0.00295)\end{array}$ & $0.08 \%$ & $\begin{array}{l}-0.00102 * * * \\
(0.00011)\end{array}$ & $-18.21 \%$ & $\begin{array}{l}-0.01572 * * * \\
(0.00205)\end{array}$ & $-1.65 \%$ & $\begin{array}{l}0.00267 * * * \\
(0.00089)\end{array}$ & $128.99 \%$ \\
\hline 63-64 years old & $\begin{array}{r}0.00485 \\
(0.00750)\end{array}$ & $0.51 \%$ & $\begin{array}{c}-0.00034 \\
(0.00023)\end{array}$ & $-9.09 \%$ & $\begin{array}{l}-0.01596 * * * \\
(0.00496)\end{array}$ & $-1.73 \%$ & $\begin{array}{c}-0.00001 \\
(0.00041)\end{array}$ & $-0.71 \%$ \\
\hline
\end{tabular}

\section{Controls:}

Age, gender, education, state of residence

Linear and quadratic trends x state, month

and year effects

Retirement controls

Anticipation controls

Unemployment benefit controls

$\begin{array}{cc}\text { yes } & \text { yes } \\ \text { yes } & \text { yes } \\ \text { yes } & \text { yes } \\ \text { yes } & \text { yes } \\ \text { no } & \text { no }\end{array}$

\begin{tabular}{|c|c|}
\hline yes & yes \\
\hline yes & yes \\
\hline yes & es \\
\hline no & no \\
\hline yes & \\
\hline
\end{tabular}

Note: Standard errors are clustered at the birth cohort-by-year-level.

$\mathrm{p}<1 \%$; **: $\mathrm{p}<5 \%$; *: $\mathrm{p}<10 \%$. RME are calculated as the relation of the agespecific marginal effect and the mean probability of the transition in the pre-reform period for the specific age group. Pre-reform period: Transitions from $E=03 / 2004$-08/2005; Transitions from U=03/2004 - 01/2006. Anticipation period: Transitions from E=09/2005 - 01/2006. Post-reform period: 02/2006 - 12/2007. Estimations include main reform effect "post-reform". For a list and definition of control variables, see Table 3.

Source: SIAB 7510 and own calculations. 

retirement, anticipation and unemployment benefits: pooled sample

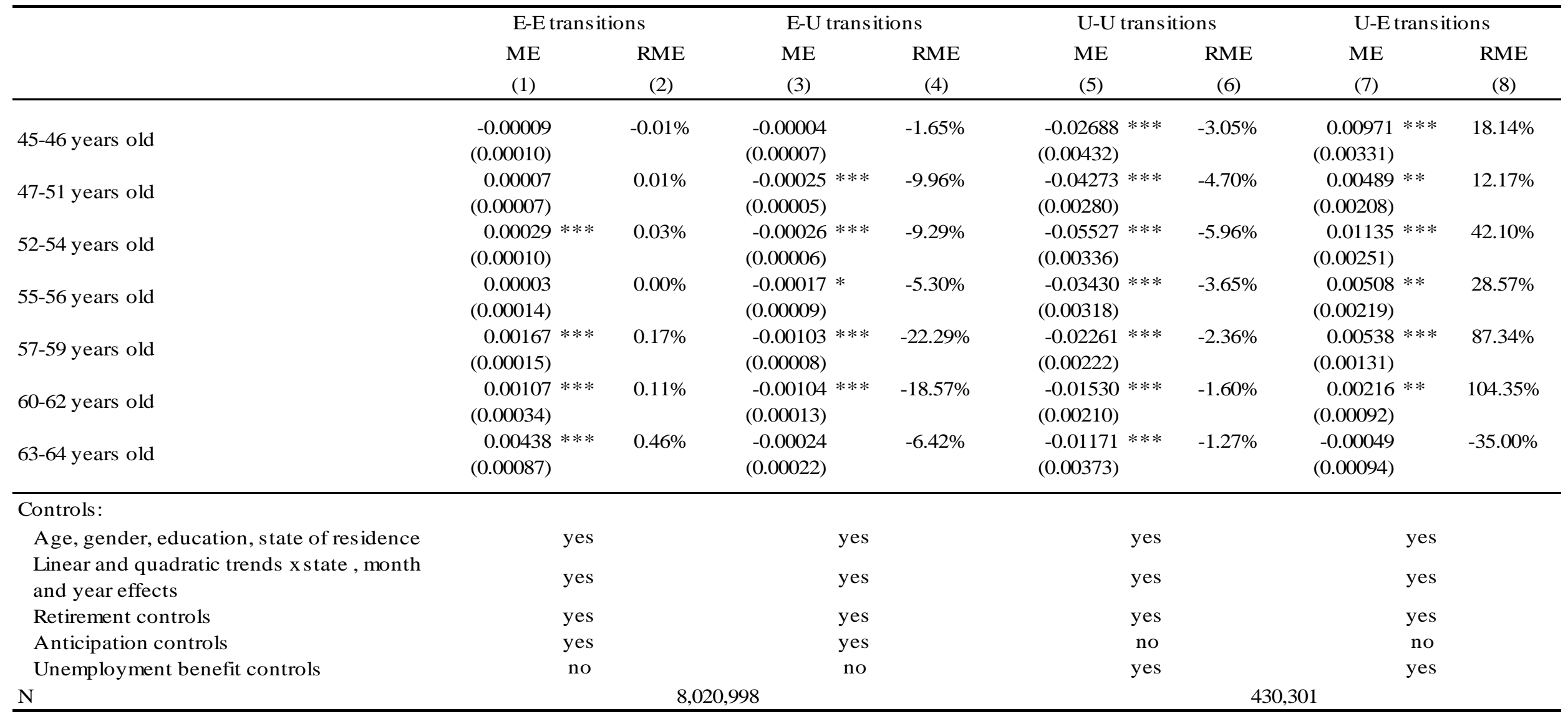

Note: Standard errors are clustered at the individual level. ***: $\mathrm{p}<1 \%$; **: $<<5$; *: $\mathrm{p}<10 \%$. RME are calculated as the relation of the age-specific marginal effect and the mean probability of the transition in the pre-reform period for the specific age group. Pre-reform period: Transitions from $E=03 / 2004$-08/2005; Transitions from U=03/2004 - 01/2006. Anticipation period: Transitions from E=09/2005 - 01/2006. Post-reform period: 02/2006 -12/2007. Estimations include main reform effect “post-reform”. For a list and definition of control variables, see Table 3.

Source: SIAB 7510 and own calculations. 

retirement, anticipation and unemployment benefits: pooled sample

\begin{tabular}{|c|c|c|c|c|c|c|c|c|}
\hline & \multicolumn{2}{|c|}{ E-E transitions } & \multicolumn{2}{|c|}{ E-U transitions } & \multicolumn{2}{|c|}{ U-U transitions } & \multicolumn{2}{|c|}{ U-E transitions } \\
\hline & $\begin{array}{l}\mathrm{ME} \\
(1) \\
\end{array}$ & $\begin{array}{l}\text { RME } \\
(2) \\
\end{array}$ & $\begin{array}{l}\text { ME } \\
\text { (3) }\end{array}$ & $\begin{array}{c}\text { RME } \\
(4) \\
\end{array}$ & $\begin{array}{l}\mathrm{ME} \\
(5) \\
\end{array}$ & $\begin{array}{c}\mathrm{RME} \\
(6) \\
\end{array}$ & $\begin{array}{l}\mathrm{ME} \\
(7) \\
\end{array}$ & $\begin{array}{c}\mathrm{RME} \\
(8) \\
\end{array}$ \\
\hline 45-46 years old & $\begin{array}{r}-0.00009 \\
(0.00010)\end{array}$ & $-0.01 \%$ & $\begin{array}{r}-0.00004 \\
(0.00007)\end{array}$ & $-1.65 \%$ & $\begin{array}{l}-0.02429 * * * \\
(0.00414)\end{array}$ & $-2.76 \%$ & $\begin{array}{l}0.01013 * * * \\
(0.00329)\end{array}$ & $18.93 \%$ \\
\hline 47-51 years old & $\begin{array}{r}0.00007 \\
(0.00007)\end{array}$ & $0.01 \%$ & $\begin{array}{l}-0.00025 * * * \\
(0.00005)\end{array}$ & $-9.96 \%$ & $\begin{array}{l}-0.03703 * * * \\
(0.00275)\end{array}$ & $-4.08 \%$ & $\begin{array}{l}0.00575 * * * \\
(0.00208)\end{array}$ & $14.31 \%$ \\
\hline $52-54$ years old & $\begin{array}{l}0.00029 * * * \\
(0.00010)\end{array}$ & $0.03 \%$ & $\begin{array}{l}-0.00026 * * * \\
(0.00006)\end{array}$ & $-9.29 \%$ & $\begin{array}{l}-0.04995 * * * \\
(0.00331)\end{array}$ & $-5.39 \%$ & $\begin{array}{l}0.01225 * * * \\
(0.00250)\end{array}$ & $45.44 \%$ \\
\hline $55-56$ years old & $\begin{array}{r}0.00004 \\
(0.00014)\end{array}$ & $0.00 \%$ & $\begin{array}{l}-0.00016 * \\
(0.00009)\end{array}$ & $-4.98 \%$ & $\begin{array}{l}-0.03084 * * * \\
(0.00315)\end{array}$ & $-3.28 \%$ & $\begin{array}{l}0.00656 * * * \\
(0.00220)\end{array}$ & $36.90 \%$ \\
\hline $57-59$ years old & $\begin{array}{l}0.00170 * * * \\
(0.00015)\end{array}$ & $0.17 \%$ & $\begin{array}{l}-0.00103 * * * \\
(0.00008)\end{array}$ & $-22.29 \%$ & $\begin{array}{l}-0.02164 * * * \\
(0.00224)\end{array}$ & $-2.26 \%$ & $\begin{array}{l}0.00647 * * * \\
(0.00131)\end{array}$ & $105.03 \%$ \\
\hline 60-62 years old & $\begin{array}{l}0.00123 * * * \\
(0.00033)\end{array}$ & $0.13 \%$ & $\begin{array}{l}-0.00103 * * * \\
(0.00013)\end{array}$ & $-18.39 \%$ & $\begin{array}{l}-0.01362 * * * \\
(0.00211)\end{array}$ & $-1.43 \%$ & $\begin{array}{l}0.00271 * * * \\
(0.00091)\end{array}$ & $130.92 \%$ \\
\hline 63-64 years old & $\begin{array}{l}0.00519 * * * \\
(0.00087)\end{array}$ & $0.55 \%$ & $\begin{array}{r}-0.00023 \\
(0.00022)\end{array}$ & $-6.15 \%$ & $\begin{array}{r}-0.00596 \\
(0.00372)\end{array}$ & $-0.64 \%$ & $\begin{array}{r}0.00003 \\
(0.00096)\end{array}$ & $2.14 \%$ \\
\hline \multicolumn{9}{|l|}{ Controls: } \\
\hline Age, gender, education, state of residence & yes & & yes & & yes & & yes & \\
\hline $\begin{array}{l}\text { Linear and quadratic trends x state, month } \\
\text { and year effects }\end{array}$ & yes & & yes & & yes & & yes & \\
\hline Retirement controls & yes & & yes & & yes & & yes & \\
\hline Anticipation controls & yes & & yes & & no & & no & \\
\hline Unemployment benefit controls & no & & no & & yes & & yes & \\
\hline $\mathrm{N}$ & \multicolumn{4}{|c|}{$8,020,998$} & \multicolumn{4}{|c|}{430,301} \\
\hline
\end{tabular}

Note: Standard errors are clustered at the individual level. ***: $\mathrm{p}<1 \%$; **: $<<5$; *: $\mathrm{p}<10 \%$. RME are calculated as the relation of the age-specific marginal effect and the mean probability of the transition in the pre-reform period for the specific age group. Pre-reform period: Transitions from $E=03 / 2004$-08/2005; Transitions from U=03/2004 - 01/2006. Anticipation period: Transitions from E=09/2005 - 01/2006. Post-reform period: 02/2006 -12/2007. Estimations include main reform effect “post-reform”. For a list and definition of control variables, see Table 3.

Source: SIAB 7510 and own calculations. 


\section{Figure 1 Transition rates over time}

1.1 Monthly employment (E-E) and unemployment stays (U-U) as a share of observations observed in employment resp. unemployment at the beginning of the ongoing month (seasonally adjusted, age 40-64, male and female)

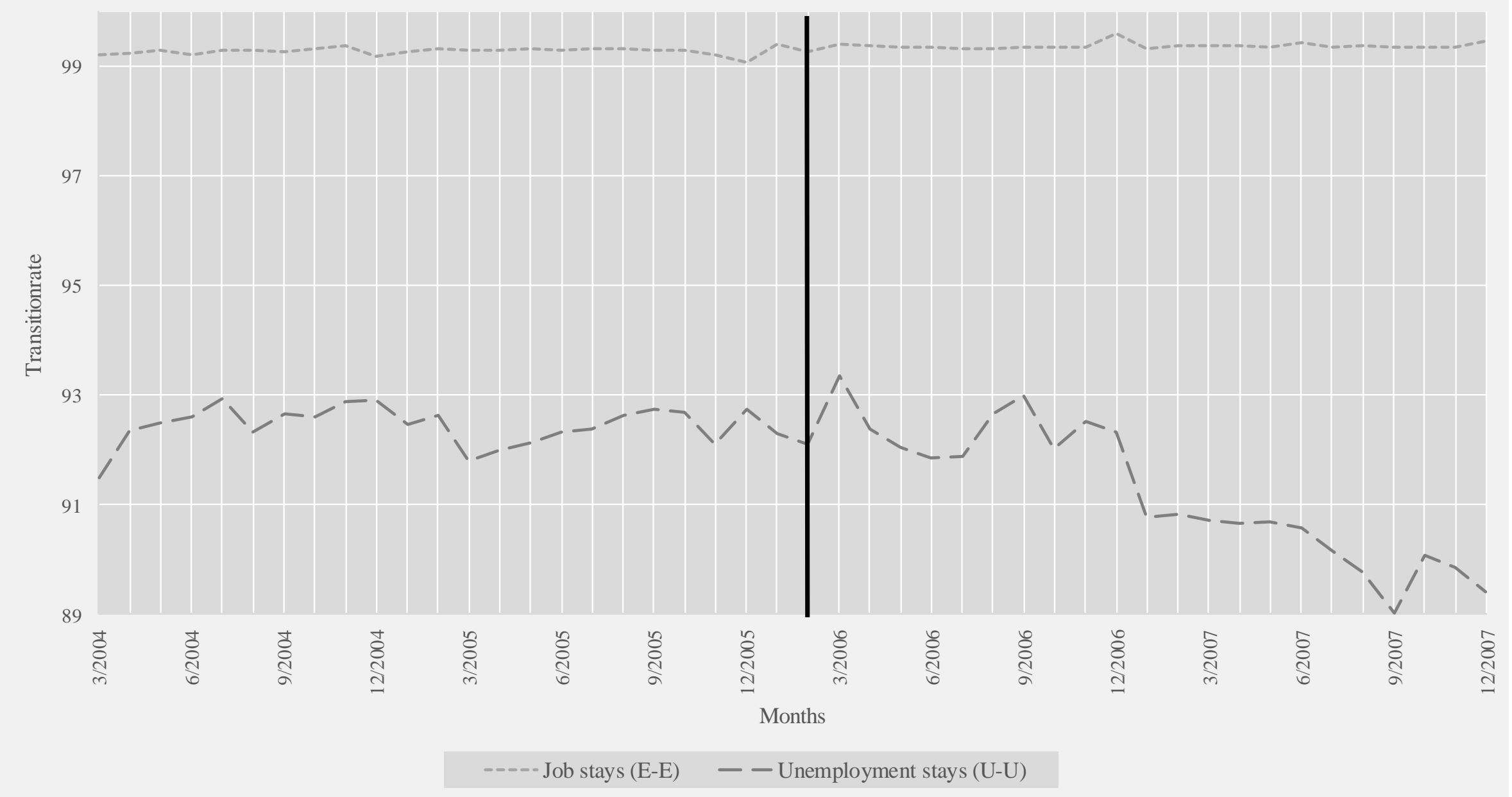

Note: Seasonally adjusted by deducting calendar month-specific average deviations from the overall mean transition rate from the observed values. Source: SIAB 7510 and own calculations. 
1.2 Monthly job separations (E-U) and findings (U-E) as a share of observations observed in employment resp. unemployment at the beginning of the ongoing month (seasonally adjusted, age 40-64, male and female)

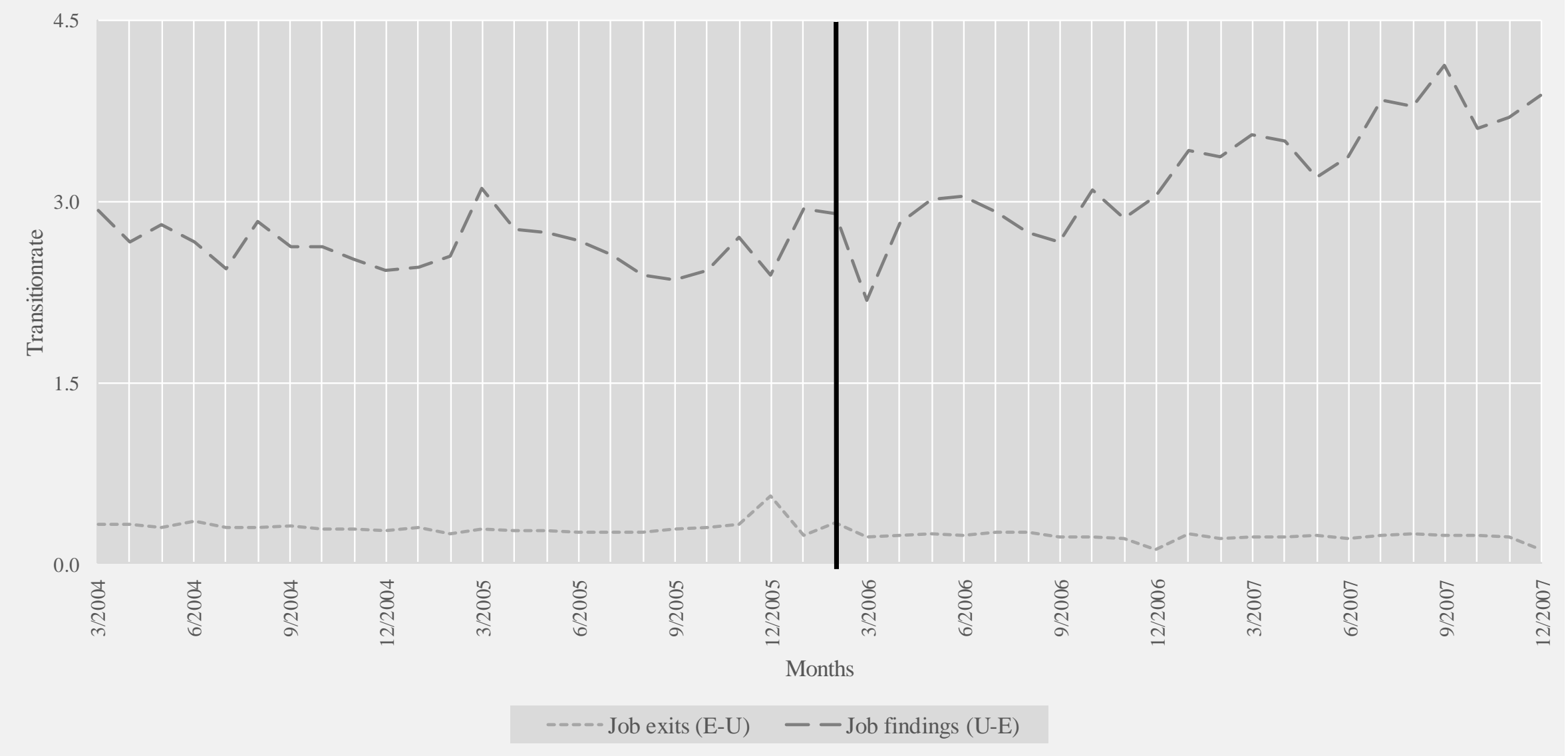

Note: Seasonally adjusted by deducting calendar month-specific average deviations from the overall mean transition rate from the observed values. Source: SIAB 7510 and own calculations. 
Figure 2 Transition rates by control and treatment group from 01/2002 to 08/2005

2.1 Monthly employment stays (E-E) as a share of observations observed in employment at the beginning of the ongoing month (seasonally adjusted)

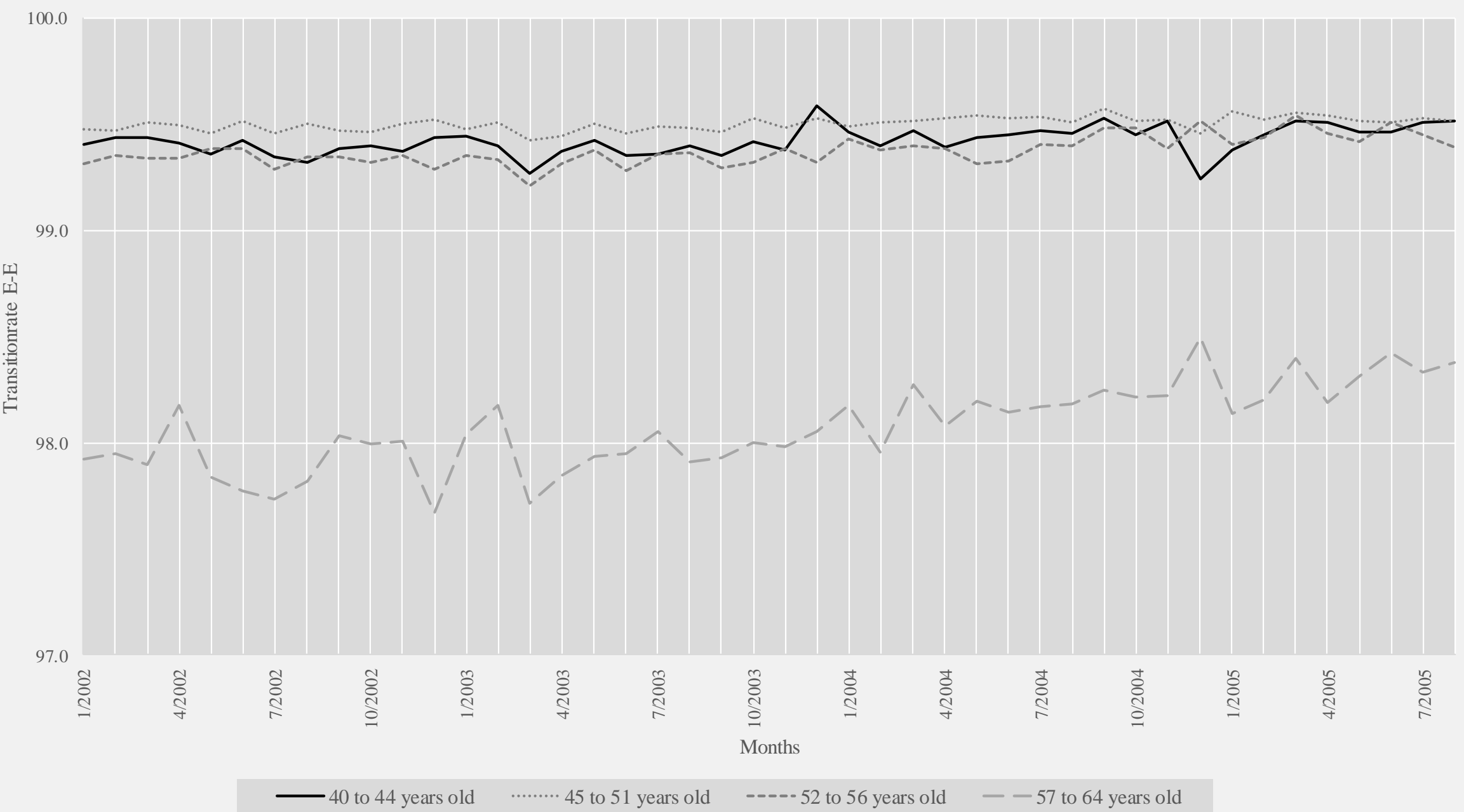

Note: Seasonally adjusted by deducting calendar month-specific average deviations from the overall mean transition rate from the observed values. Source: SIAB 7510 and own calculations. 


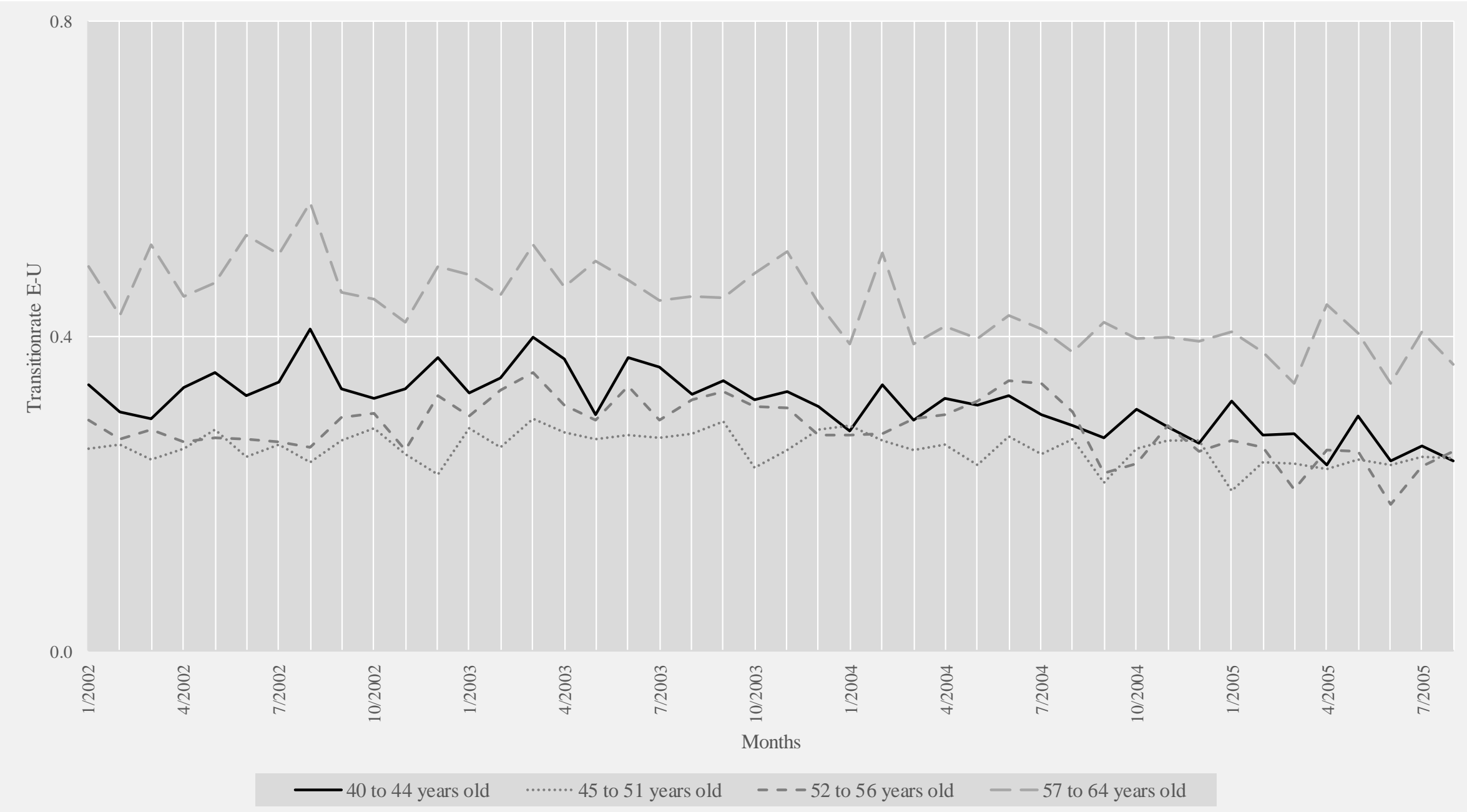

Note: Seasonally adjusted by deducting calendar month-specific average deviations from the overall mean transition rate from the observed values. Source: SIAB 7510 and own calculations. 


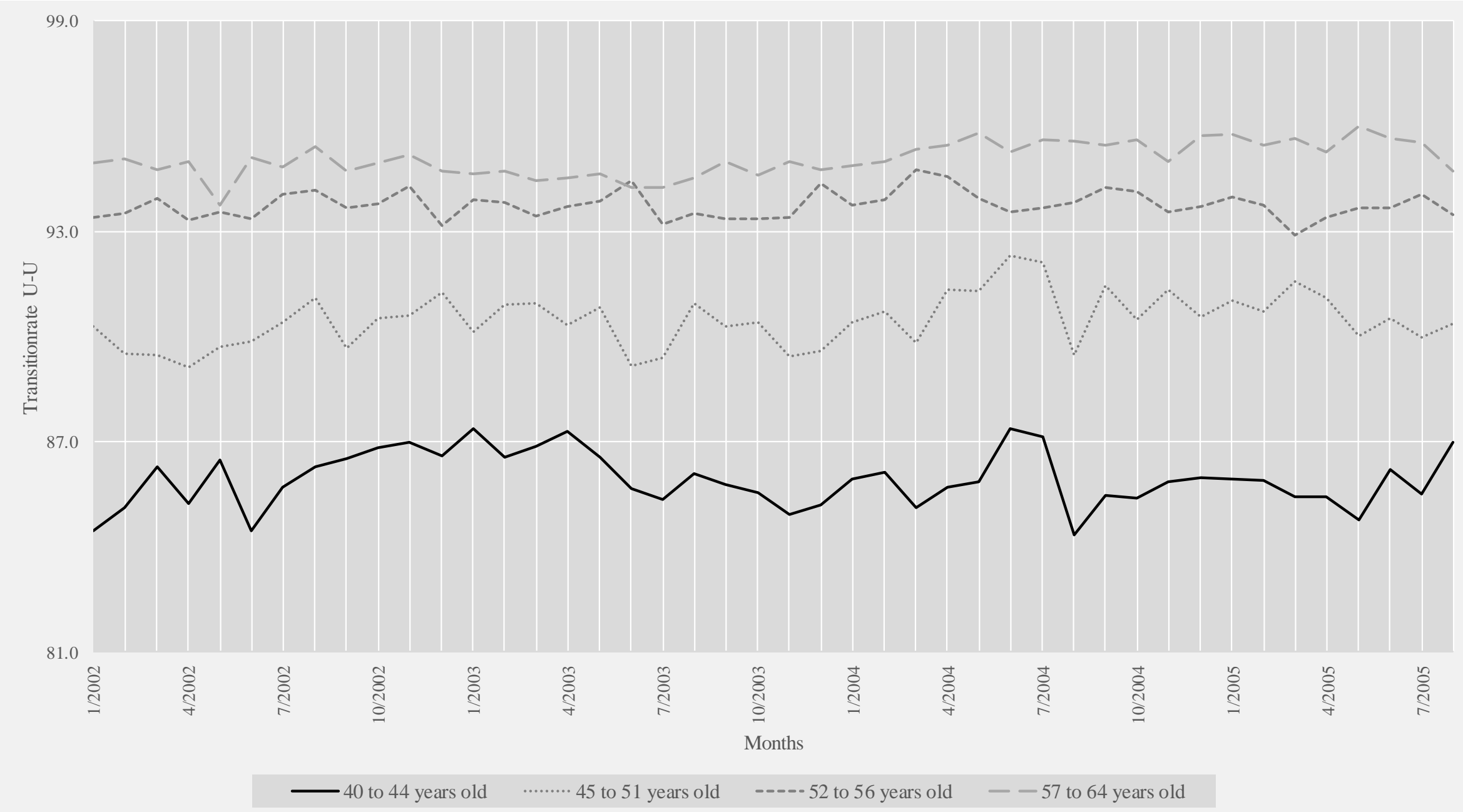

Note: Seasonally adjusted by deducting calendar month-specific average deviations from the overall mean transition rate from the observed values. Source: SIAB 7510 and own calculations. 
2.4 Monthly job findings (U-E) as a share of observations observed in employment and unemployment at the beginning of the ongoing month (seasonally adjusted

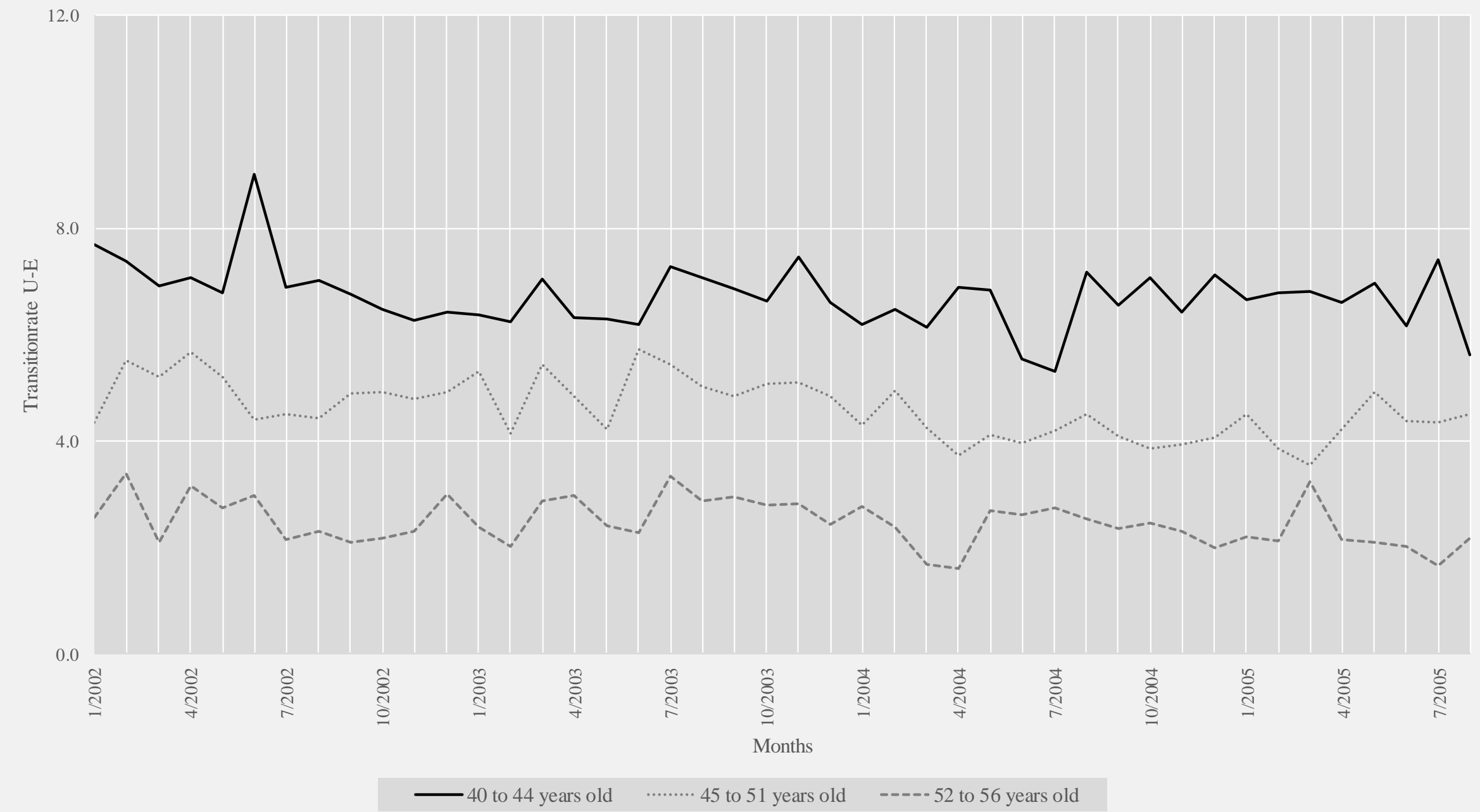

Note: Seasonally adjusted by deducting calendar month-specific average deviations from the overall mean transition rate from the observed values. Transition rate for 57 to 62 year-olds not available because of too few transitions.

Source: SIAB 7510 and own calculations. 


\section{Appendix A}

Table A.1 Duration of unemployment benefit receipt (in months) by age and insurance months (pre-reform regulation)

\begin{tabular}{ccc}
\hline Age & $\begin{array}{c}\text { Minimum number of } \\
\text { insurance months }\end{array}$ & $\begin{array}{c}\text { Duration of } \\
\text { unemployment } \\
\text { benefit receipt } \\
\text { (months) }\end{array}$ \\
\hline all ages & 12 & 6 \\
all ages & 16 & 8 \\
all ages & 20 & 10 \\
all ages & 24 & 12 \\
$>44$ & 28 & 14 \\
$>44$ & 32 & 16 \\
$>44$ & 36 & 18 \\
$>46$ & 40 & 20 \\
$>46$ & 44 & 22 \\
$>51$ & 48 & 24 \\
$>51$ & 52 & 26 \\
$>56$ & 56 & 28 \\
$>56$ & 60 & 30 \\
$>56$ & 64 & 32 \\
\hline
\end{tabular}

Note: Under the pre-reform regime, unemployment benefit eligibility required that the individual was employed for at least 12 months within the last 3 years or since the last receipt of unemployment benefits within the last 3 years. To be eligible for the maximum transfer duration, individuals 57 years old and older needed up to 64 months of employment within the last 7 years or since the last receipt of unemployment benefits within the last 7 years.

Remaining claims from a previous unemployment benefit receipt can be added to new unemployment benefit entitlements up to the age-specific maximum entitlement lengths if the remaining claims are not older than 4 years. This means that individuals can also get the agespecific maximum entitlement lengths without having the required number of months in employment (e.g. a 60-years-old has 56 insurance months but remaining claims of 4 months).

Source: BGBL.I, 1997, p. 627; BGBL.I, 2003, p. 3004; BGBL.I, 2008, p. 681 
Table A.2 Descriptive statistics of transitions by age groups and by gender

A.2.1 Pooled sample

\begin{tabular}{|c|c|c|c|c|c|c|c|c|c|}
\hline & $\begin{array}{c}40-44 \\
\text { years old }\end{array}$ & $\begin{array}{c}45-46 \\
\text { years old }\end{array}$ & $\begin{array}{c}47-51 \\
\text { years old }\end{array}$ & $\begin{array}{c}52-54 \\
\text { years old }\end{array}$ & $\begin{array}{c}55-56 \\
\text { years old }\end{array}$ & $\begin{array}{c}57-59 \\
\text { years old }\end{array}$ & $\begin{array}{c}60-62 \\
\text { years old }\end{array}$ & $\begin{array}{c}63-64 \\
\text { years old }\end{array}$ & $\begin{array}{c}40-64 \\
\text { years old }\end{array}$ \\
\hline \multicolumn{10}{|c|}{ Transitions from Employment } \\
\hline $\mathrm{N}$ & $2,420,238$ & 856,198 & $1,900,432$ & $1,025,320$ & 625,432 & 691,033 & 400,727 & 101,618 & 8,020,998 \\
\hline Share E-E=yes & 0.9948 & 0.9955 & 0.9954 & 0.9948 & 0.9938 & 0.9915 & 0.9782 & 0.9509 & 0.9933 \\
\hline Share E-U=yes & 0.0027 & 0.0023 & 0.0022 & 0.0024 & 0.0028 & 0.0034 & 0.0044 & 0.0032 & 0.0026 \\
\hline \multicolumn{10}{|c|}{ Transitions from Unemployment } \\
\hline $\mathrm{N}$ & 66,292 & 23,482 & 67,123 & 49,890 & 44,521 & 76,936 & 80,958 & 21,099 & 430,301 \\
\hline Share $\mathrm{U}-\mathrm{U}=$ yes & 0.8519 & 0.8758 & 0.9037 & 0.9214 & 0.9373 & 0.9558 & 0.9551 & 0.9286 & 0.9200 \\
\hline Share U-E=yes & 0.0726 & 0.0606 & 0.0443 & 0.0308 & 0.0203 & 0.0073 & 0.0024 & 0.0015 & 0.0289 \\
\hline
\end{tabular}

\section{A.2.2 Men}

\begin{tabular}{|c|c|c|c|c|c|c|c|c|c|}
\hline & $\begin{array}{c}40-44 \\
\text { years old }\end{array}$ & $\begin{array}{c}45-46 \\
\text { years old }\end{array}$ & $\begin{array}{c}47-51 \\
\text { years old }\end{array}$ & $\begin{array}{c}52-54 \\
\text { years old }\end{array}$ & $\begin{array}{c}55-56 \\
\text { years old }\end{array}$ & $\begin{array}{c}57-59 \\
\text { years old }\end{array}$ & $\begin{array}{c}60-62 \\
\text { years old }\end{array}$ & $\begin{array}{c}63-64 \\
\text { years old }\end{array}$ & $\begin{array}{c}40-64 \\
\text { years old }\end{array}$ \\
\hline \multicolumn{10}{|c|}{ Transitions from Employment } \\
\hline $\mathrm{N}$ & $1,234,247$ & 422,706 & 949,721 & 527,074 & 323,435 & 369,349 & 235,665 & 72,061 & $4,134,258$ \\
\hline Share $E-E=$ yes & 0.9957 & 0.9959 & 0.9958 & 0.9952 & 0.9943 & 0.9924 & 0.9811 & 0.9531 & 0.9933 \\
\hline Share E-U=yes & 0.0023 & 0.0020 & 0.0020 & 0.0022 & 0.0025 & 0.0029 & 0.0044 & 0.0033 & 0.0026 \\
\hline \multicolumn{10}{|c|}{ Transitions from Unemployment } \\
\hline $\mathrm{N}$ & 26,218 & 9,405 & 27,925 & 21,162 & 19,806 & 35,081 & 43,377 & 15,621 & 198,595 \\
\hline Share U-U=yes & 0.8375 & 0.8657 & 0.8965 & 0.915 & 0.9349 & 0.9545 & 0.9569 & 0.9339 & 0.9200 \\
\hline Share U-E=yes & 0.0815 & 0.0659 & 0.0498 & 0.0366 & 0.0222 & 0.0083 & 0.0028 & 0.0015 & 0.0289 \\
\hline
\end{tabular}

\section{A.2.3 Women}

\begin{tabular}{|c|c|c|c|c|c|c|c|c|c|}
\hline & $\begin{array}{c}40-44 \\
\text { years old }\end{array}$ & $\begin{array}{c}45-46 \\
\text { years old }\end{array}$ & $\begin{array}{c}47-51 \\
\text { years old }\end{array}$ & $\begin{array}{c}52-54 \\
\text { years old }\end{array}$ & $\begin{array}{c}55-56 \\
\text { years old }\end{array}$ & $\begin{array}{c}57-59 \\
\text { years old }\end{array}$ & $\begin{array}{c}60-62 \\
\text { years old }\end{array}$ & $\begin{array}{c}63-64 \\
\text { years old }\end{array}$ & $\begin{array}{c}40-64 \\
\text { years old }\end{array}$ \\
\hline \multicolumn{10}{|c|}{ Transitions from Employment } \\
\hline $\mathrm{N}$ & $1,185,991$ & 433,492 & 950,711 & 498,246 & 301,997 & 321,684 & 165,062 & 29,557 & $3,886,740$ \\
\hline Share E-E=yes & 0.9938 & 0.9951 & 0.9950 & 0.9944 & 0.9934 & 0.9904 & 0.9742 & 0.9455 & 0.9933 \\
\hline Share E-U=yes & 0.0031 & 0.0025 & 0.0025 & 0.0026 & 0.0031 & 0.0040 & 0.0044 & 0.0030 & 0.0026 \\
\hline \multicolumn{10}{|c|}{ Transitions from Unemployment } \\
\hline $\mathrm{N}$ & 40,074 & 14,077 & 39,198 & 28,728 & 24,715 & 41,855 & 37,581 & 5,478 & 231,706 \\
\hline Share U-U=yes & 0.8614 & 0.8825 & 0.9089 & 0.9262 & 0.9392 & 0.9570 & 0.9531 & 0.9137 & 0.9200 \\
\hline Share U-E=yes & 0.0668 & 0.0571 & 0.0403 & 0.0266 & 0.0187 & 0.0065 & 0.0020 & 0.0015 & 0.0289 \\
\hline
\end{tabular}

Note: Share is calculated as the mean sum of the respective monthly transitions in percent of all monthly transitions from E resp. U.

Source: SIAB 7510 and own calculations. 
Table A.3 Descriptive statistics of explanatory variable

\begin{tabular}{|c|c|c|c|c|}
\hline & \multicolumn{2}{|c|}{ Transitions from Employment } & \multicolumn{2}{|c|}{ Transitions from Unemployment } \\
\hline & Mean & Std. Dev. & Mean & Std. Dev. \\
\hline Post-reform & 0.5081 & 0.4999 & 0.1726 & 0.3779 \\
\hline Post-reform x $40-44$ years old & 0.1518 & 0.3588 & 0.0477 & 0.2132 \\
\hline Post-reform x 45-46 years old & 0.0544 & 0.2269 & 0.0151 & 0.1219 \\
\hline Post-reform x 47-51 years old & 0.1199 & 0.3248 & 0.0309 & 0.1731 \\
\hline Post-reform x $52-54$ years old & 0.0636 & 0.2440 & 0.0182 & 0.1337 \\
\hline Post-reform x 55-56 years old & 0.0403 & 0.1966 & 0.0165 & 0.1275 \\
\hline Post-reform x 57-59 years old & 0.0465 & 0.2106 & 0.0215 & 0.1452 \\
\hline Post-reform x 60-62 years old & 0.0243 & 0.1540 & 0.0167 & 0.1280 \\
\hline Post-reform x 63-64 years old & 0.0074 & 0.0855 & 0.0059 & 0.0767 \\
\hline \multicolumn{5}{|l|}{ Age groups } \\
\hline 40-44 years old & 0.3017 & 0.4590 & 0.1541 & 0.3610 \\
\hline 45-46 years old & 0.1067 & 0.3088 & 0.0546 & 0.2271 \\
\hline 47-51 years old & 0.2369 & 0.4252 & 0.1560 & 0.3628 \\
\hline 52-54 years old & 0.1278 & 0.3339 & 0.1159 & 0.3202 \\
\hline $55-56$ years old & 0.0780 & 0.2681 & 0.1035 & 0.3046 \\
\hline 57-59 years old & 0.0862 & 0.2806 & 0.1788 & 0.3832 \\
\hline 60-62 years old & 0.0500 & 0.2179 & 0.1881 & 0.3908 \\
\hline 63-64 years old & 0.0127 & 0.1118 & 0.0490 & 0.2159 \\
\hline Female & 0.4846 & 0.4998 & 0.5385 & 0.4985 \\
\hline \multicolumn{5}{|l|}{ Education groups } \\
\hline $\begin{array}{l}\text { No university degree \& no } \\
\text { vocational training }\end{array}$ & 0.0835 & 0.2766 & 0.1155 & 0.3196 \\
\hline Vocational training & 0.7496 & 0.4333 & 0.7531 & 0.4312 \\
\hline Univ. degree/techn. college & 0.1498 & 0.3569 & 0.1009 & 0.3011 \\
\hline Education missing & 0.0171 & 0.1298 & 0.0305 & 0.1720 \\
\hline Early retirement & 0.0179 & 0.1328 & 0.1337 & 0.3404 \\
\hline Full retirement & 0.0022 & 0.0464 & 0.0078 & 0.0880 \\
\hline Distance to early retirement & 13.4969 & 6.9026 & 8.5010 & 7.6680 \\
\hline Distance to full retirement & 16.4037 & 6.6962 & 11.7578 & 7.2432 \\
\hline Antic & 0.1085 & 0.3110 & - & - \\
\hline Antic $x 40-44$ years old & 0.0327 & 0.1780 & - & - \\
\hline Antic x 45-46 years old & 0.0116 & 0.1073 & - & - \\
\hline Antic x 47-51 years old & 0.0257 & 0.1581 & - & - \\
\hline Antic x 52-54 years old & 0.0139 & 0.1171 & - & - \\
\hline Antic x 55-56 years old & 0.0086 & 0.0922 & - & - \\
\hline Antic x 57-59 years old & 0.0092 & 0.0956 & - & - \\
\hline Antic x 60-62 years old & 0.0055 & 0.0738 & - & - \\
\hline Antic x 63-64 years old & 0.0013 & 0.0359 & - & - \\
\hline reg58 & 0.0082 & 0.0901 & - & - \\
\hline Remaining entitlement of UB & - & - & 0.8624 & 0.3445 \\
\hline Days of past UB receipt in current spell & - & - & 343.60 & 244.42 \\
\hline $\mathrm{N}$ & \multicolumn{2}{|c|}{$8,020,998$} & \multicolumn{2}{|c|}{430,301} \\
\hline
\end{tabular}

Source: SIAB 7510 and own calculations. 
Table A.4 Logit coefficients of the reform effects on labor market transitions controlling for retirement, anticipation, and employment benefits: men

\begin{tabular}{|c|c|c|c|c|}
\hline & $\begin{array}{c}\text { E-E transitions } \\
\text { (1) }\end{array}$ & $\begin{array}{c}\text { E-U transitions } \\
\text { (2) }\end{array}$ & $\begin{array}{l}\text { U-U transitions } \\
\text { (3) }\end{array}$ & $\begin{array}{c}\text { U-E transitions } \\
\text { (4) }\end{array}$ \\
\hline Post-reform & $\begin{array}{l}-0.4127 * * * \\
(0.0763)\end{array}$ & $\begin{array}{l}0.7996 * * * \\
(0.1217)\end{array}$ & $\begin{array}{l}-0.1200 * * \\
(0.0549)\end{array}$ & $\begin{array}{l}-0.1574 * * \\
(0.0644)\end{array}$ \\
\hline Post-reform x 45-46 years old & $\begin{array}{r}-0.0339 \\
(0.0607)\end{array}$ & $\begin{array}{r}-0.0048 \\
(0.0841)\end{array}$ & $\begin{array}{l}-0.2465 * * * \\
(0.0939)\end{array}$ & $\begin{array}{r}0.0763 \\
(0.1020)\end{array}$ \\
\hline Post-reform x 47-51 years old & $\begin{array}{r}0.0011 \\
(0.0460)\end{array}$ & $\begin{array}{l}-0.1719 * * * \\
(0.0645)\end{array}$ & $\begin{array}{l}-0.5937 * * * \\
(0.0774)\end{array}$ & $\begin{array}{r}0.0908 \\
(0.0812)\end{array}$ \\
\hline Post-reform $x$ 52-54 years old & $\begin{array}{l}0.1093 * * \\
(0.0530)\end{array}$ & $\begin{array}{l}-0.2925 * * * \\
(0.0770)\end{array}$ & $\begin{array}{l}-0.8724 * * * \\
(0.0931)\end{array}$ & $\begin{array}{l}0.2563 * * \\
(0.1005)\end{array}$ \\
\hline Post-reform x 55-56 years old & $\begin{array}{r}-0.0634 \\
(0.0597)\end{array}$ & $\begin{array}{r}-0.0198 \\
(0.0878)\end{array}$ & $\begin{array}{l}-0.5994 * * * \\
(0.1006)\end{array}$ & $\begin{array}{r}0.1790 \\
(0.1218)\end{array}$ \\
\hline Post-reform x 57-59 years old & $\begin{array}{r}0.0648 \\
(0.0574)\end{array}$ & $\begin{array}{l}-0.2666 * * * \\
(0.0917)\end{array}$ & $\begin{array}{l}-0.4190 * * * \\
(0.1002)\end{array}$ & $\begin{array}{l}0.3601 * * \\
(0.1528)\end{array}$ \\
\hline Post-reform x 60-62 years old & $\begin{array}{l}-0.0936 * * \\
(0.0456)\end{array}$ & $\begin{array}{l}-0.3698 * * * \\
(0.0863)\end{array}$ & $\begin{array}{l}-0.4425 * * * \\
(0.1160)\end{array}$ & $\begin{array}{r}0.3785 \\
(0.2362)\end{array}$ \\
\hline Post-reform x 63-64 years old & $\begin{array}{l}0.1431 * * * \\
(0.0502)\end{array}$ & $\begin{array}{l}-0.2754 * \\
(0.1508)\end{array}$ & $\begin{array}{l}-0.3594 * * * \\
(0.1347)\end{array}$ & $\begin{array}{r}0.4029 \\
(0.4797)\end{array}$ \\
\hline Controls: & & & & \\
\hline Age, education, state of residence & yes & yes & yes & yes \\
\hline $\begin{array}{l}\text { Linear and quadratic trends x state, } \\
\text { month and year effects }\end{array}$ & yes & yes & yes & yes \\
\hline Retirement controls & yes $^{\circ}$ & yes $^{\circ}$ & yes & yes + \\
\hline Anticipation controls & yes & yes & no & no \\
\hline Unemployment benefit controls & no & no & yes & yes \\
\hline $\mathrm{N}$ & \multicolumn{2}{|c|}{ 4.134.258 } & \multicolumn{2}{|c|}{198.595} \\
\hline Mean & 0,9937 & 0,0024 & 0,9194 & 0,0292 \\
\hline
\end{tabular}

Note: Standard errors are clustered at the individual level. ***: $\mathrm{p}<1 \%$; ** $\mathrm{p}<5 \%$; *: $\mathrm{p}<10 \%$. Pre-reform period: Transitions from E=03/2004 -08/2005; Transitions from U=03/2004 01/2006. Anticipation period: Transitions from E=09/2005 - 01/2006. Post-reform period: 02/2006 - 12/2007. For a list and definition of control variables, see Table $3 .{ }^{\circ}$ No controls for early and full retirement due to few observations with eligibility for retirement. +One control for early and full retirement eligibility due to few observations with eligibility.

Source: SIAB 7510 and own calculations. 
Table A.5 Logit coefficients of the reform effects on labor market transitions controlling for retirement, anticipation, and employment benefits: women

\begin{tabular}{|c|c|c|c|c|}
\hline & $\begin{array}{c}\text { E-E transitions } \\
\text { (1) }\end{array}$ & $\begin{array}{c}\text { E-U transitions } \\
(2) \\
\end{array}$ & $\begin{array}{c}\text { U-U transitions } \\
\text { (3) }\end{array}$ & $\begin{array}{c}\text { U-E transitions } \\
(4)\end{array}$ \\
\hline Post-reform & $\begin{array}{l}-0.2649 * * * \\
(0.0734)\end{array}$ & $\begin{array}{l}0.5693 * * * \\
(0.1168)\end{array}$ & $\begin{array}{r}-0.0368 \\
(0.0486)\end{array}$ & $\begin{array}{r}-0.0644 \\
(0.0592)\end{array}$ \\
\hline Post-reform x $45-46$ years old & $\begin{array}{r}-0.0104 \\
(0.0541)\end{array}$ & $\begin{array}{r}-0.0387 \\
(0.0739)\end{array}$ & $\begin{array}{l}-0.3372 * * * \\
(0.0818)\end{array}$ & $\begin{array}{l}0.2190 * * \\
(0.0856)\end{array}$ \\
\hline Post-reform $x$ 47-51 years old & $\begin{array}{r}0.0549 \\
(0.0410)\end{array}$ & $\begin{array}{l}-0.1181 * * \\
(0.0572)\end{array}$ & $\begin{array}{l}-0.6791 * * * \\
(0.0696)\end{array}$ & $\begin{array}{l}0.1479 * * \\
(0.0726)\end{array}$ \\
\hline Post-reform x $52-54$ years old & $\begin{array}{r}-0.0780 \\
(0.0533)\end{array}$ & $\begin{array}{r}0.1116 \\
(0.0789)\end{array}$ & $\begin{array}{l}-1.0086 * * * \\
(0.0873)\end{array}$ & $\begin{array}{l}0.3582 * * * \\
(0.0970)\end{array}$ \\
\hline Post-reform x $55-56$ years old & $\begin{array}{r}0.0233 \\
(0.0568)\end{array}$ & $\begin{array}{r}-0.0749 \\
(0.0818)\end{array}$ & $\begin{array}{l}-0.9239 * * * \\
(0.0988)\end{array}$ & $\begin{array}{l}0.2482 * * \\
(0.1230)\end{array}$ \\
\hline Post-reform x 57-59 years old & $\begin{array}{l}0.2773 * * * \\
(0.0485)\end{array}$ & $\begin{array}{l}-0.3883 * * * \\
(0.0747)\end{array}$ & $\begin{array}{l}-0.7747 * * * \\
(0.0947)\end{array}$ & $\begin{array}{l}0.5819 * * * \\
(0.1494)\end{array}$ \\
\hline Post-reform x 60-62 years old & $\begin{array}{l}0.1201 * * * \\
(0.0439)\end{array}$ & $\begin{array}{r}-0.1055 \\
(0.0947)\end{array}$ & $\begin{array}{l}-0.7814 * * * \\
(0.1131)\end{array}$ & $\begin{array}{l}0.9089 * * * \\
(0.2668)\end{array}$ \\
\hline Post-reform x 63-64 years old & $\begin{array}{l}-0.2128 * * * \\
(0.0720)\end{array}$ & $\begin{array}{c}0.4898 * \\
(0.2878)\end{array}$ & $\begin{array}{l}-0.5166 * * * \\
(0.1693)\end{array}$ & ${ }^{\circ}$ \\
\hline Controls: & & & & \\
\hline Age, education, state of residence & yes & yes & yes & yes \\
\hline $\begin{array}{l}\text { Linear and quadratic trends x state, } \\
\text { month and year effects }\end{array}$ & yes & yes & yes & yes \\
\hline Retirement controls & yes & yes & yes & yes \\
\hline Anticipation controls & yes & yes & no & no \\
\hline Unemployment benefit controls & no & no & yes & yes \\
\hline $\mathrm{N}$ & \multicolumn{2}{|c|}{$3,886,740$} & \multicolumn{2}{|c|}{231,706} \\
\hline Mean & 0.9928 & 0.0029 & 0.9204 & 0.0287 \\
\hline
\end{tabular}

Note: Standard errors are clustered at the individual level. ***: $\mathrm{p}<1 \%$; **: $\mathrm{p}<5 \%$; *: $\mathrm{p}<10 \%$. Prereform period: Transitions from E=03/2004 -08/2005; Transitions from U=03/2004 -01/2006. Anticipation period: Transitions from E=09/2005 - 01/2006. Post-reform period: 02/2006 12/2007. For a list and definition of control variables, see Table 3. ${ }^{\circ}$ Estimations for $63-64-y e a r-$ olds not possible due to no observations with transitions from $\mathrm{U}$ to $\mathrm{E}$ in post-reform period in the age group.

Source: SIAB 7510 and own calculations. 
Table A.6 Logit estimates of marginal effects (ME) and relative marginal effects (RME) of the reform on labor market transitions controlling for retirement, anticipation and unemployment benefits: men

\begin{tabular}{|c|c|c|c|c|c|c|c|c|}
\hline & \multicolumn{2}{|c|}{ E-E transitions } & \multicolumn{2}{|c|}{ E-U transitions } & \multicolumn{2}{|c|}{ U-U transitions } & \multicolumn{2}{|c|}{ U-E transitions } \\
\hline & $\begin{array}{l}\text { ME } \\
(1)\end{array}$ & $\begin{array}{l}\text { RME } \\
(2)\end{array}$ & $\begin{array}{l}\text { ME } \\
\text { (3) }\end{array}$ & $\begin{array}{l}\text { RME } \\
\text { (4) }\end{array}$ & $\begin{array}{l}\mathrm{ME} \\
\text { (5) }\end{array}$ & $\begin{array}{l}\text { RME } \\
(6)\end{array}$ & $\begin{array}{l}\mathrm{ME} \\
(7)\end{array}$ & $\begin{array}{l}\text { RME } \\
(8)\end{array}$ \\
\hline 45-46 years old & $\begin{array}{r}-0.00013 \\
(0.00014)\end{array}$ & $-0.01 \%$ & $\begin{array}{r}-0.00001 \\
(0.00009)\end{array}$ & $-0.47 \%$ & $\begin{array}{l}-0.02639 * * * \\
(0.00755)\end{array}$ & $-3.03 \%$ & $\begin{array}{r}0.00551 \\
(0.00544)\end{array}$ & $9.20 \%$ \\
\hline 47-51 years old & $\begin{array}{r}0.00000 \\
(0.00009)\end{array}$ & $0.00 \%$ & $\begin{array}{l}-0.00032 * * * \\
(0.00006)\end{array}$ & $-14.48 \%$ & $\begin{array}{l}-0.05019 * * * \\
(0.00483)\end{array}$ & $-5.56 \%$ & $\begin{array}{r}0.00545 \\
(0.00343)\end{array}$ & $11.95 \%$ \\
\hline $52-54$ years old & $\begin{array}{l}0.00047 \text { *** } \\
(0.00013)\end{array}$ & $0.05 \%$ & $\begin{array}{l}-0.00055 * * * \\
(0.00008)\end{array}$ & $-22.27 \%$ & $\begin{array}{l}-0.06387 * * * \\
(0.00605)\end{array}$ & $-6.93 \%$ & $\begin{array}{l}0.01306 * * * \\
(0.00438)\end{array}$ & $40.20 \%$ \\
\hline 57-59 years old & $\begin{array}{l}0.00043 * * \\
(0.00022)\end{array}$ & $0.04 \%$ & $\begin{array}{l}-0.00061 * * * \\
(0.00011)\end{array}$ & $-19.74 \%$ & $\begin{array}{l}-0.01648 * * * \\
(0.00342)\end{array}$ & $-1.73 \%$ & $\begin{array}{l}0.00545 * * * \\
(0.00208)\end{array}$ & $78.08 \%$ \\
\hline 60-62 years old & $\begin{array}{l}-0.00156 * * * \\
(0.00041)\end{array}$ & $-0.16 \%$ & $\begin{array}{l}-0.00130 * * * \\
(0.00017)\end{array}$ & $-28.45 \%$ & $\begin{array}{l}-0.01214 * * * \\
(0.00307)\end{array}$ & $-1.27 \%$ & $\begin{array}{r}0.00206 \\
(0.00134)\end{array}$ & $83.40 \%$ \\
\hline 63-64 years old & $\begin{array}{l}0.006011^{* * *} \\
(0.00103)\end{array}$ & $0.64 \%$ & $\begin{array}{l}-0.00084 * * * \\
(0.00026)\end{array}$ & $-22.89 \%$ & $\begin{array}{l}-0.01181 * * * \\
(0.00441)\end{array}$ & $-1.27 \%$ & $\begin{array}{r}0.00118 \\
(0.00146)\end{array}$ & $91.47 \%$ \\
\hline Anticipation controls & yes & & yes & & no & & no & \\
\hline Unemployment benefit controls & no & & no & & yes & & yes & \\
\hline $\mathrm{N}$ & \multicolumn{4}{|c|}{$4,134,258$} & \multicolumn{4}{|c|}{198,595} \\
\hline $\begin{array}{l}\text { Note: Standard errors are clustered at th } \\
\text { the mean probability of the trans } \\
\text { Transitions from } \mathrm{U}=03 / 2004-01 / 2 \\
\text { include main reform effect "post-I } \\
\text { with eligibility for retirement. +Or }\end{array}$ & $\begin{array}{l}\text { vidual level. }{ }^{* *} \\
\text { in the pre-refo } \\
\text { Anticipation p } \\
\text { n”. For a list ar } \\
\text { trol for early a }\end{array}$ & $\begin{array}{l}\mathrm{p}<10 \\
\text { period } \\
\text { od: Tra } \\
\text { definiti }\end{array}$ & $\begin{array}{l}\mathrm{k}^{*}: \mathrm{p}<5 \% ; * \\
\mathrm{r} \text { the specific } \\
\text { tions from } \mathrm{E}=0 \\
\text { of control varia } \\
\text { nent eligibility }\end{array}$ & $\begin{array}{l}<10 \% \\
\text { group } \\
2005- \\
\text { es, see }\end{array}$ & $\begin{array}{l}\text { show the ratio } \\
\text { form period: } \\
\text { 6. Post-reform } \\
\text { 3. }{ }^{\circ} \text { No control } \\
\text { vations with e }\end{array}$ & $\begin{array}{l}\text { of the aq } \\
\text { ransitio } \\
\text { eriod: } 0 \\
\text { for retil }\end{array}$ & $\begin{array}{l}\text { cific marginal } \\
\text { om } E=03 / 2004 \\
06-12 / 2007 \\
\text { th due to few ol }\end{array}$ & $\begin{array}{l}\text { ffect ove } \\
-08 / 2005 \\
\text { stimations } \\
\text { servations }\end{array}$ \\
\hline
\end{tabular}


Table A.7 Logit estimates of marginal effects (ME) and relative marginal effects (RME) of the reform on labor market transitions controlling for retirement, anticipation and unemployment benefits: women

\begin{tabular}{|c|c|c|c|c|c|c|c|c|}
\hline & \multicolumn{2}{|c|}{ E-E transitions } & \multicolumn{2}{|c|}{ E-U transitions } & \multicolumn{2}{|c|}{ U-U transitions } & \multicolumn{2}{|c|}{ U-E transitions } \\
\hline & $\begin{array}{l}\mathrm{ME} \\
(1) \\
\end{array}$ & $\begin{array}{l}\mathrm{RME} \\
(2) \\
\end{array}$ & $\begin{array}{l}\text { ME } \\
\text { (3) } \\
\end{array}$ & $\begin{array}{c}\mathrm{RME} \\
(4) \\
\end{array}$ & $\begin{array}{l}\text { ME } \\
(5) \\
\end{array}$ & $\begin{array}{c}\text { RME } \\
(6) \\
\end{array}$ & $\begin{array}{l}\text { ME } \\
(7) \\
\end{array}$ & $\begin{array}{c}\text { RME } \\
(8) \\
\end{array}$ \\
\hline 45-46 years old & $\begin{array}{r}-0.00005 \\
(0.00015)\end{array}$ & $-0.01 \%$ & $\begin{array}{r}-0.00009 \\
(0.00010)\end{array}$ & $-3.33 \%$ & $\begin{array}{l}-0.03088 * * * \\
(0.00552)\end{array}$ & $-3.48 \%$ & $\begin{array}{l}0.01420 * * * \\
(0.00409)\end{array}$ & $28.86 \%$ \\
\hline 47-51 years old & $\begin{array}{l}0.00027 * * \\
(0.00010)\end{array}$ & $0.03 \%$ & $\begin{array}{l}-0.00028 * * * \\
(0.00007)\end{array}$ & $-10.37 \%$ & $\begin{array}{l}-0.04729 * * * \\
(0.00339)\end{array}$ & $-5.18 \%$ & $\begin{array}{l}0.00734 * * * \\
(0.00259)\end{array}$ & $20.24 \%$ \\
\hline $52-54$ years old & $\begin{array}{l}-0.00039 * * \\
(0.00015)\end{array}$ & $-0.04 \%$ & $\begin{array}{l}0.00025 * * \\
(0.00010)\end{array}$ & $9.40 \%$ & $\begin{array}{l}-0.05691 * * * \\
(0.00399)\end{array}$ & $-6.11 \%$ & $\begin{array}{l}0.01327 * * * \\
(0.00298)\end{array}$ & $58.23 \%$ \\
\hline $55-56$ years old & $\begin{array}{r}0.00014 \\
(0.00021)\end{array}$ & $0.01 \%$ & $\begin{array}{r}-0.00020 \\
(0.00013)\end{array}$ & $-6.33 \%$ & $\begin{array}{l}-0.03998 * * * \\
(0.00418)\end{array}$ & $-4.25 \%$ & $\begin{array}{l}0.00650 * * \\
(0.00289)\end{array}$ & $39.13 \%$ \\
\hline $57-59$ years old & $\begin{array}{l}0.00250 * * * \\
(0.00022)\end{array}$ & $0.25 \%$ & $\begin{array}{l}-0.00132 * * * \\
(0.00013)\end{array}$ & $-30.48 \%$ & $\begin{array}{l}-0.02284 * * * \\
(0.00277)\end{array}$ & $-2.39 \%$ & $\begin{array}{l}0.00599 * * * \\
(0.00166)\end{array}$ & $109.51 \%$ \\
\hline 60-62 years old & $\begin{array}{l}0.00290 * * * \\
(0.00057)\end{array}$ & $0.30 \%$ & $\begin{array}{l}-0.00039 * \\
(0.00022)\end{array}$ & $-8.69 \%$ & $\begin{array}{l}-0.01833 * * * \\
(0.00281)\end{array}$ & $-1.93 \%$ & $\begin{array}{l}0.00321 * * * \\
(0.00121)\end{array}$ & $199.38 \%$ \\
\hline 63-64 years old & $\begin{array}{l}-0.01001 * * * \\
(0.00170)\end{array}$ & $-1.05 \%$ & $\begin{array}{l}0.00126 * * * \\
(0.00042)\end{array}$ & $62.69 \%$ & $\begin{array}{l}-0.01917 * * * \\
(0.00668)\end{array}$ & $-2.11 \%$ & $-\circ$ & $\begin{array}{l}-\circ \\
-\circ\end{array}$ \\
\hline \multicolumn{9}{|l|}{ Controls: } \\
\hline Age, education, state of residence & yes & & yes & & yes & & yes & \\
\hline $\begin{array}{l}\text { Linear and quadratic trends x state, month } \\
\text { and year effects }\end{array}$ & yes & & yes & & yes & & yes & \\
\hline Retirement controls & yes & & yes & & yes & & yes & \\
\hline Anticipation controls & yes & & yes & & no & & no & \\
\hline Unemployment benefit controls & no & & no & & yes & & yes & \\
\hline $\mathrm{N}$ & \multicolumn{4}{|c|}{$3,886,740$} & \multicolumn{4}{|c|}{231,706} \\
\hline
\end{tabular}

Note: $\quad$ Standard errors are clustered at the individual level. $* * *$ : $<1 \%$; **: $\mathrm{p}<5 \%$; $: \mathrm{p}<10 \%$. RME show the ratio of the age-specific marginal effect over the mean probability of the transition in the pre-reform period for the specific age group. Pre-reform period: Transitions from E=03/2004 -08/2005; Transitions from U=03/2004 -01/2006. Anticipation period: Transitions from $E=09 / 2005$ - 01/2006. Post-reform period: 02/2006 - 12/2007. Estimations include main reform effect "post-reform". For a list and definition of control variables, see Table 3. ${ }^{\circ E s t i m a t i o n s ~ f o r ~ 63-64-y e a r-o l d s ~ n o t ~ p o s s i b l e ~ d u e ~ t o ~}$ no observations with transitions from $\mathrm{U}$ to $\mathrm{E}$ in post-reform period in the age group.

Source: SIAB 7510 and own calculations. 
Table A.8 Logit coefficients of the reform effects on labor market transitions controlling for retirement, anticipation, and employment benefits: low educated individuals

\begin{tabular}{|c|c|c|c|c|}
\hline & $\begin{array}{c}\text { E-E transitions } \\
\text { (1) } \\
\end{array}$ & $\begin{array}{c}\text { E-U transitions } \\
\text { (2) }\end{array}$ & $\begin{array}{l}\text { U-U transitions } \\
\text { (3) }\end{array}$ & $\begin{array}{c}\text { U-E transitions } \\
\text { (4) } \\
\end{array}$ \\
\hline Post-reform & $\begin{array}{l}-0.3194 * * \\
(0.1625)\end{array}$ & $\begin{array}{l}0.6929 * * * \\
(0.2600)\end{array}$ & $\begin{array}{l}0.2099 * \\
(0.1250)\end{array}$ & $\begin{array}{r}-0.1015 \\
(0.1562)\end{array}$ \\
\hline Post-reform x 45 -46 years old & $\begin{array}{r}-0.0793 \\
(0.1323)\end{array}$ & $\begin{array}{r}-0.1016 \\
(0.1902)\end{array}$ & $\begin{array}{r}-0.2960 \\
(0.2024)\end{array}$ & $\begin{array}{r}0.1617 \\
(0.2480)\end{array}$ \\
\hline Post-reform x 47-51 years old & $\begin{array}{r}0.1194 \\
(0.0996)\end{array}$ & $\begin{array}{r}-0.2265 \\
(0.1389)\end{array}$ & $\begin{array}{l}-1.0979 * * * \\
(0.1730)\end{array}$ & $\begin{array}{r}0.1850 \\
(0.2004)\end{array}$ \\
\hline Post-reform x 52-54 years old & $\begin{array}{r}0.1439 \\
(0.1191)\end{array}$ & $\begin{array}{r}-0.1912 \\
(0.1769)\end{array}$ & $\begin{array}{l}-1.3060 * * * \\
(0.1973)\end{array}$ & $\begin{array}{r}0.1853 \\
(0.2502)\end{array}$ \\
\hline Post-reform x 55-56 years old & $\begin{array}{r}0.0412 \\
(0.1259)\end{array}$ & $\begin{array}{r}-0.0886 \\
(0.1870)\end{array}$ & $\begin{array}{l}-1.2198 * * * \\
(0.2447)\end{array}$ & $\begin{array}{r}0.3059 \\
(0.3108)\end{array}$ \\
\hline Post-reform x 57-59 years old & $\begin{array}{l}0.2585 * * \\
(0.1054)\end{array}$ & $\begin{array}{r}-0.2129 \\
(0.1585)\end{array}$ & $\begin{array}{l}-0.7756 * * * \\
(0.2210)\end{array}$ & $\begin{array}{r}0.4847 \\
(0.3873)\end{array}$ \\
\hline Post-reform x 60-62 years old & $\begin{array}{r}0.1479 \\
(0.0986)\end{array}$ & $\begin{array}{r}-0.2866 \\
(0.1948)\end{array}$ & $\begin{array}{l}-0.8182 * * * \\
(0.2621)\end{array}$ & $\begin{array}{r}0.2585 \\
(0.8444)\end{array}$ \\
\hline Post-reform x 63-64 years old & $\begin{array}{r}-0.0272 \\
(0.1247)\end{array}$ & $\begin{array}{r}0.1307 \\
(0.4225)\end{array}$ & $\begin{array}{l}-0.9539 * * * \\
(0.3197)\end{array}$ & $-^{\circ}{ }^{\circ}$ \\
\hline Controls: & & & & \\
\hline Age, gender, state of residence & yes & yes & yes & yes \\
\hline $\begin{array}{l}\text { Linear and quadratic trends x state, } \\
\text { month and year effects }\end{array}$ & yes & yes & yes & yes \\
\hline Retirement controls & yes & yes & yes & yes + \\
\hline Anticipation controls & yes & yes & no & no \\
\hline Unemployment benefit controls & no & no & yes & yes \\
\hline $\mathrm{N}$ & \multicolumn{2}{|c|}{669,371} & \multicolumn{2}{|c|}{49,693} \\
\hline Mean & 0.9914 & 0.0031 & 0.9280 & 0.0183 \\
\hline
\end{tabular}

Note: Standard errors are clustered at the individual level. $* * *$ : $<<1 \%$; $*$ : $\mathrm{p}<5 \%$; $: \mathrm{p}<10 \%$. Prereform period: Transitions from E=03/2004 -08/2005; Transitions from U=03/2004 -01/2006. Anticipation period: Transitions from E=09/2005 - 01/2006. Post-reform period: 02/2006 12/2007. For a list and definition of control variables, see Table 3 . $^{\circ}$ Estimations for $63-64-y e a r-$ olds not possible due to no observations with transitions from $\mathrm{U}$ to $\mathrm{E}$ in post-reform period in the age group. +One control for early and full retirement eligibility due to few observations with eligibility.

Source: SIAB 7510 and own calculations. 
Table A.9 Logit coefficients of the reform effects on labor market transitions controlling for retirement, anticipation, and employment benefits: middle educated individuals

\begin{tabular}{|c|c|c|c|c|}
\hline & $\begin{array}{c}\text { E-E transitions } \\
\text { (1) }\end{array}$ & $\begin{array}{c}\text { E-U transitions } \\
\text { (2) }\end{array}$ & $\begin{array}{c}\text { U-U transitions } \\
\text { (3) }\end{array}$ & $\begin{array}{c}\text { U-E transitions } \\
\text { (4) } \\
\end{array}$ \\
\hline Post-reform & $\begin{array}{l}-0.3680 * * * \\
(0.0615)\end{array}$ & $\begin{array}{l}0.6522 * * * \\
(0.0965)\end{array}$ & $\begin{array}{l}-0.0827 * \\
(0.0424)\end{array}$ & $\begin{array}{r}-0.0773 \\
(0.0497)\end{array}$ \\
\hline Post-reform x 45-46 years old & $\begin{array}{r}-0.0133 \\
(0.0468)\end{array}$ & $\begin{array}{r}0.0005 \\
(0.0635)\end{array}$ & $\begin{array}{l}-0.2713 * * * \\
(0.0721)\end{array}$ & $\begin{array}{c}0.1299 * \\
(0.0742)\end{array}$ \\
\hline Post-reform x 47-51 years old & $\begin{array}{r}-0.0358 \\
(0.0354)\end{array}$ & $\begin{array}{r}-0.0507 \\
(0.0491)\end{array}$ & $\begin{array}{l}-0.6179 * * * \\
(0.0593)\end{array}$ & $\begin{array}{l}0.1131 * \\
(0.0608)\end{array}$ \\
\hline Post-reform x 52-54 years old & $\begin{array}{c}0.0750 * \\
(0.0423)\end{array}$ & $\begin{array}{l}-0.1161 * \\
(0.0605)\end{array}$ & $\begin{array}{l}-0.9028 * * * \\
(0.0726)\end{array}$ & $\begin{array}{l}0.2398 * * * \\
(0.0784)\end{array}$ \\
\hline Post-reform x 55-56 years old & $\begin{array}{r}0.0105 \\
(0.0470)\end{array}$ & $\begin{array}{r}-0.0792 \\
(0.0681)\end{array}$ & $\begin{array}{l}-0.7698 * * * \\
(0.0808)\end{array}$ & $\begin{array}{l}0.2343 * * \\
(0.0967)\end{array}$ \\
\hline Post-reform x 57-59 years old & $\begin{array}{l}0.1992 * * * \\
(0.0414)\end{array}$ & $\begin{array}{l}-0.3876 * * * \\
(0.0647)\end{array}$ & $\begin{array}{l}-0.7008 * * * \\
(0.0781)\end{array}$ & $\begin{array}{l}0.5600 * * * \\
(0.1173)\end{array}$ \\
\hline Post-reform x 60-62 years old & $\begin{array}{r}0.0147 \\
(0.0364)\end{array}$ & $\begin{array}{l}-0.2993 * * * \\
(0.0725)\end{array}$ & $\begin{array}{l}-0.6355 * * * \\
(0.0917)\end{array}$ & $\begin{array}{l}0.5515 * * * \\
(0.2073)\end{array}$ \\
\hline Post-reform x 63-64 years old & $\begin{array}{l}0.1047 \text { ** } \\
(0.0467)\end{array}$ & $\begin{array}{r}-0.1336 \\
(0.1528)\end{array}$ & $\begin{array}{l}-0.3357 * * * \\
(0.1292)\end{array}$ & $\begin{array}{r}-0.0905 \\
(0.5546)\end{array}$ \\
\hline Controls: & & & & \\
\hline Age, gender, state of residence & yes & yes & yes & yes \\
\hline $\begin{array}{l}\text { Linear and quadratic trends x state, } \\
\text { month and year effects }\end{array}$ & yes & yes & yes & yes \\
\hline Retirement controls & yes & yes & yes & yes \\
\hline Anticipation controls & yes & yes & no & no \\
\hline Unemployment benefit controls & no & no & yes & yes \\
\hline $\mathrm{N}$ & \multicolumn{2}{|c|}{$6,012,295$} & \multicolumn{2}{|c|}{324,075} \\
\hline Mean & 0.9933 & 0.0027 & 0.9202 & 0.0299 \\
\hline
\end{tabular}

Note: Standard errors are clustered at the individual level. ${ }^{* *}$ : $\mathrm{p}<1 \%$; ${ }^{* *}$ : $\mathrm{p}<5 \%$; : $\mathrm{p}<10 \%$. P Pre-reform period: Transitions from E=03/2004 -08/2005; Transitions from U=03/2004 01/2006. Anticipation period: Transitions from E=09/2005 - 01/2006. Post-reform period: 02/2006 - 12/2007. For a list and definition of control variables, see Table 3.

Source: SIAB 7510 and own calculations. 
Table A.10 Logit coefficients of the reform effects on labor market transitions controlling for retirement, anticipation, and employment benefits: highly educated individuals

\begin{tabular}{|c|c|c|c|c|}
\hline & $\begin{array}{c}\text { E-E transitions } \\
\text { (1) }\end{array}$ & $\begin{array}{c}\text { E-U transitions } \\
\text { (2) }\end{array}$ & $\begin{array}{c}\text { U-U transitions } \\
\text { (3) }\end{array}$ & $\begin{array}{c}\text { U-E transitions } \\
\text { (4) }\end{array}$ \\
\hline Post-reform & $\begin{array}{l}-0.2774 * \\
(0.1478)\end{array}$ & $\begin{array}{l}0.8719 * * * \\
(0.2530)\end{array}$ & $\begin{array}{r}-0.1141 \\
(0.0947)\end{array}$ & $\begin{array}{r}-0.1862 \\
(0.1181)\end{array}$ \\
\hline Post-reform x 45-46 years old & $\begin{array}{r}-0.0762 \\
(0.1126)\end{array}$ & $\begin{array}{r}-0.0396 \\
(0.1582)\end{array}$ & $\begin{array}{l}-0.3439 * * \\
(0.1560)\end{array}$ & $\begin{array}{r}0.2015 \\
(0.1864)\end{array}$ \\
\hline Post-reform x 47-51 years old & $\begin{array}{l}0.1902 * * \\
(0.0841)\end{array}$ & $\begin{array}{l}-0.4233 * * * \\
(0.1194)\end{array}$ & $\begin{array}{l}-0.2767 * \\
(0.1433)\end{array}$ & $\begin{array}{r}-0.0568 \\
(0.1570)\end{array}$ \\
\hline Post-reform x 52-54 years old & $\begin{array}{r}-0.1266 \\
(0.1089)\end{array}$ & $\begin{array}{r}-0.0813 \\
(0.1634)\end{array}$ & $\begin{array}{l}-0.8580 * * * \\
(0.1869)\end{array}$ & $\begin{array}{l}0.5236 * * * \\
(0.1974)\end{array}$ \\
\hline Post-reform x 55-56 years old & $\begin{array}{r}-0.0907 \\
(0.1306)\end{array}$ & $\begin{array}{r}0.1010 \\
(0.1883)\end{array}$ & $\begin{array}{l}-0.3399 * \\
(0.1963)\end{array}$ & $\begin{array}{r}0.1286 \\
(0.2670)\end{array}$ \\
\hline Post-reform x 57-59 years old & $\begin{array}{l}0.3060 * * * \\
(0.1165)\end{array}$ & $\begin{array}{l}-0.5017 * * * \\
(0.1833)\end{array}$ & $\begin{array}{l}-0.5329 * * * \\
(0.2055)\end{array}$ & $\begin{array}{r}0.4536 \\
(0.2974)\end{array}$ \\
\hline Post-reform x 60-62 years old & $\begin{array}{r}0.0400 \\
(0.0877)\end{array}$ & $\begin{array}{r}-0.2039 \\
(0.1824)\end{array}$ & $\begin{array}{r}-0.3321 \\
(0.2741)\end{array}$ & $\begin{array}{l}0.8619 * * \\
(0.4024)\end{array}$ \\
\hline Post-reform x 63-64 years old & $\begin{array}{r}0.0210 \\
(0.0936)\end{array}$ & $\begin{array}{r}-0.2274 \\
(0.3419)\end{array}$ & $\begin{array}{l}-0.6278 * * * \\
(0.2423)\end{array}$ & $\begin{array}{r}0.9066 \\
(0.8939)\end{array}$ \\
\hline Controls: & & & & \\
\hline Age, gender, state of residence & yes & yes & yes & yes \\
\hline $\begin{array}{l}\text { Linear and quadratic trends x state, } \\
\text { month and year effects }\end{array}$ & yes & yes & yes & yes \\
\hline Retirement controls & yes & yes & yes & yes \\
\hline Anticipation controls & yes & yes & no & no \\
\hline Unemployment benefit controls & no & no & yes & yes \\
\hline $\mathrm{N}$ & \multicolumn{2}{|c|}{$1,201,836$} & \multicolumn{2}{|c|}{43,401} \\
\hline Mean & 0.9945 & 0.0021 & 0.9075 & 0.0366 \\
\hline
\end{tabular}

Note: Standard errors are clustered at the individual level. $* * *$ : $<1 \%$; $* *$ : $<5 \%$; $:$ p $<10 \%$. Pre-reform period: Transitions from E=03/2004 -08/2005; Transitions from U=03/2004 01/2006. Anticipation period: Transitions from E=09/2005 - 01/2006. Post-reform period: 02/2006 - 12/2007. For a list and definition of control variables, see Table 3.

Source: SIAB 7510 and own calculations. 
Table A.11 Logit estimates of marginal effects (ME) and relative marginal effects (RME) of the reform on labor market transitions controlling for retirement, anticipation and unemployment benefits: low educated individuals

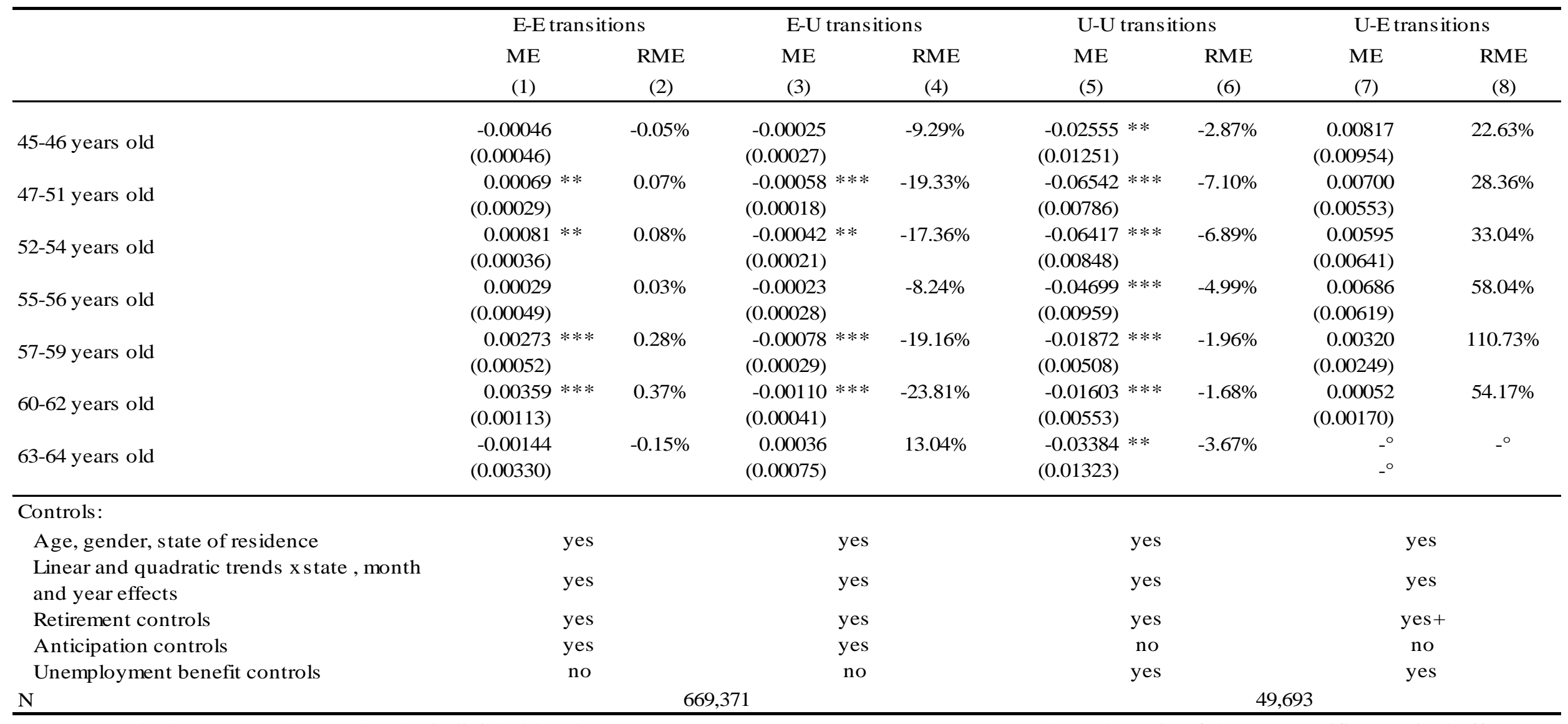

Note: Standard errors are clustered at the individual level. ***: $\mathrm{p}<1 \%$; **: $\mathrm{p}<5 \%$; $: \mathrm{p}<10 \%$. RME show the ratio of the age-specific marginal effect over the mean probability of the transition in the pre-reform period for the specific age group. Pre-reform period: Transitions from E=03/2004 -08/2005; Transitions from U=03/2004 -01/2006. Anticipation period: Transitions from E=09/2005 - 01/2006. Post-reform period: 02/2006 - 12/2007. Estimations include main reform effect "post-reform". For a list and definition of control variables, see Table 3. ${ }^{\circ}$ Estimations for 63-64-year-olds not possible due to no observations with transitions from $\mathrm{U}$ to $\mathrm{E}$ in post-reform period in the age group. +One control for early and full retirement eligibility due to few observations with eligibility.

Source: SIAB 7510 and own calculations. 
Table A.12 Logit estimates of marginal effects (ME) and relative marginal effects (RME) of the reform on labor market transitions controlling for retirement, anticipation and unemployment benefits: middle educated individuals:

\begin{tabular}{|c|c|c|c|c|c|c|c|c|}
\hline & \multicolumn{2}{|c|}{ E-E transitions } & \multicolumn{2}{|c|}{ E-U transitions } & \multicolumn{2}{|c|}{ U-U transitions } & \multicolumn{2}{|c|}{ U-E transitions } \\
\hline & $\begin{array}{l}\mathrm{ME} \\
(1)\end{array}$ & $\begin{array}{l}\text { RME } \\
(2) \\
\end{array}$ & $\begin{array}{l}\text { ME } \\
\text { (3) }\end{array}$ & $\begin{array}{l}\text { RME } \\
(4) \\
\end{array}$ & $\begin{array}{l}\text { ME } \\
(5)\end{array}$ & $\begin{array}{c}\text { RME } \\
(6)\end{array}$ & $\begin{array}{l}\text { ME } \\
(7) \\
\end{array}$ & $\begin{array}{c}\text { RME } \\
\text { (8) }\end{array}$ \\
\hline 45-46 years old & $\begin{array}{r}-0.00006 \\
(0.00012)\end{array}$ & $-0.01 \%$ & $\begin{array}{r}0.00000 \\
(0.00008)\end{array}$ & $0.00 \%$ & $\begin{array}{l}-0.02645 * * * \\
(0.00526)\end{array}$ & $-3.00 \%$ & $\begin{array}{l}0.00913 * * \\
(0.00380)\end{array}$ & $16.57 \%$ \\
\hline 47-51 years old & $\begin{array}{l}-0.00015 * \\
(0.00008)\end{array}$ & $-0.02 \%$ & $\begin{array}{l}-0.00010 * \\
(0.00005)\end{array}$ & $-4.20 \%$ & $\begin{array}{l}-0.04802 * * * \\
(0.00325)\end{array}$ & $-5.29 \%$ & $\begin{array}{l}0.00652 * * * \\
(0.00247)\end{array}$ & $15.62 \%$ \\
\hline 52-54 years old & $\begin{array}{l}0.00037 * * * \\
(0.00012)\end{array}$ & $0.04 \%$ & $\begin{array}{l}-0.00025 * * * \\
(0.00007)\end{array}$ & $-9.33 \%$ & $\begin{array}{l}-0.05758 * * * \\
(0.00394)\end{array}$ & $-6.21 \%$ & $\begin{array}{l}0.01066 * * * \\
(0.00291)\end{array}$ & $37.60 \%$ \\
\hline 55-56 years old & $\begin{array}{r}0.00006 \\
(0.00016)\end{array}$ & $0.01 \%$ & $\begin{array}{l}-0.00020 * * \\
(0.00010)\end{array}$ & $-6.69 \%$ & $\begin{array}{l}-0.03674 * * * \\
(0.00366)\end{array}$ & $-3.91 \%$ & $\begin{array}{l}0.00698 * * * \\
(0.00253)\end{array}$ & $38.39 \%$ \\
\hline 57-59 years old & $\begin{array}{l}0.00159 * * * \\
(0.00017)\end{array}$ & $0.16 \%$ & $\begin{array}{l}-0.00111 * * * \\
(0.00010)\end{array}$ & $-29.60 \%$ & $\begin{array}{l}-0.02327 * * * \\
(0.00248)\end{array}$ & $-2.43 \%$ & $\begin{array}{l}0.00693 * * * \\
(0.00153)\end{array}$ & $111.24 \%$ \\
\hline 60-62 years old & $\begin{array}{r}0.00030 \\
(0.00040)\end{array}$ & $0.03 \%$ & $\begin{array}{l}-0.00113 * * * \\
(0.00016)\end{array}$ & $-23.74 \%$ & $\begin{array}{l}-0.01668 * * * \\
(0.00243)\end{array}$ & $-1.75 \%$ & $\begin{array}{l}0.00248 * * \\
(0.00106)\end{array}$ & $118.66 \%$ \\
\hline 63-64 years old & $\begin{array}{l}0.00488 * * * \\
(0.00107)\end{array}$ & $0.52 \%$ & $\begin{array}{r}-0.00043 \\
(0.00027)\end{array}$ & $-11.78 \%$ & $\begin{array}{l}-0.01088 * * * \\
(0.00421)\end{array}$ & $-1.18 \%$ & $\begin{array}{r}-0.00020 \\
(0.00105)\end{array}$ & $-15.15 \%$ \\
\hline
\end{tabular}

\section{Controls:}

Age, gender, state of residence

Linear and quadratic trends x state, month

and year effects

Retirement controls

Anticipation controls

Unemployment benefit controls

$\begin{array}{cc}\text { yes } & \text { yes } \\ \text { yes } & \text { yes } \\ \text { yes } & \text { yes } \\ \text { yes } & \text { yes } \\ \text { no } & \text { no }\end{array}$

$6,012,295$

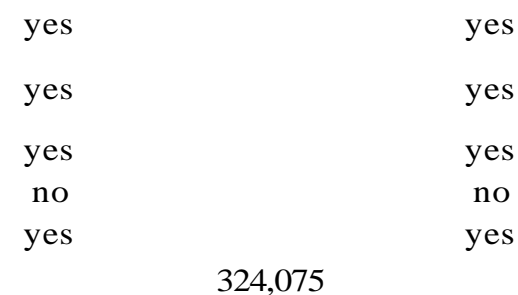

Note: Standard errors are clustered at the individual level. $* * *$ : $p<1 \%$; $* *$ : p $<5 \%$; $*$ : $p<10 \%$. RME are calculated as the relation of the age-specific marginal effect and the mean probability of the transition in the pre-reform period for the specific age group. Pre-reform period: Transitions from $E=03 / 2004$-08/2005; Transitions from U=03/2004 -01/2006. Anticipation period: Transitions from E=09/2005 - 01/2006. Post-reform period: 02/2006 12/2007. Estimations include main reform effect “post-reform”. For a list and definition of control variables, see Table 3.

Source: SIAB 7510 and own calculations. 
Table A.13 Logit estimates of marginal effects (ME) and relative marginal effects (RME) of the reform on labor market transitions controlling for retirement, anticipation and unemployment benefits: highly educated individuals

\begin{tabular}{|c|c|c|c|c|c|c|c|c|}
\hline & \multicolumn{2}{|c|}{ E-E transitions } & \multicolumn{2}{|c|}{ E-U transitions } & \multicolumn{2}{|c|}{ U-U transitions } & \multicolumn{2}{|c|}{ U-E transitions } \\
\hline & $\begin{array}{c}\text { ME } \\
(1)\end{array}$ & $\begin{array}{c}\text { RME } \\
(2) \\
\end{array}$ & $\begin{array}{c}\text { ME } \\
\text { (3) }\end{array}$ & $\begin{array}{c}\text { RME } \\
\text { (4) }\end{array}$ & $\begin{array}{c}\text { ME } \\
(5) \\
\end{array}$ & $\begin{array}{c}\mathrm{RME} \\
(6) \\
\end{array}$ & $\begin{array}{c}\text { ME } \\
(7) \\
\end{array}$ & $\begin{array}{c}\text { RME } \\
\text { (8) }\end{array}$ \\
\hline 45-46 years old & $\begin{array}{r}-0.00026 \\
(0.00023)\end{array}$ & $-0.03 \%$ & $\begin{array}{r}-0.00007 \\
(0.00016)\end{array}$ & $-3.54 \%$ & $\begin{array}{l}-0.04004 * * * \\
(0.01333)\end{array}$ & $-4.64 \%$ & $\begin{array}{r}0.01506 \\
(0.01048)\end{array}$ & $24.08 \%$ \\
\hline 47-51 years old & $\begin{array}{l}0.00062 * * * \\
(0.00015)\end{array}$ & $0.06 \%$ & $\begin{array}{l}-0.00073 * * * \\
(0.00010)\end{array}$ & $-31.47 \%$ & $\begin{array}{l}-0.02469 * * \\
(0.00961)\end{array}$ & $-2.76 \%$ & $\begin{array}{r}-0.00321 \\
(0.00626)\end{array}$ & $-6.57 \%$ \\
\hline 52-54 years old & $\begin{array}{l}-0.00043 * \\
(0.00023)\end{array}$ & $-0.04 \%$ & $\begin{array}{r}-0.00012 \\
(0.00014)\end{array}$ & $-7.32 \%$ & $\begin{array}{l}-0.07197 * * * \\
(0.01355)\end{array}$ & $-7.82 \%$ & $\begin{array}{l}0.02828 * * * \\
(0.00958)\end{array}$ & $89.83 \%$ \\
\hline 55-56 years old & $\begin{array}{r}-0.00035 \\
(0.00031)\end{array}$ & $-0.04 \%$ & $\begin{array}{r}0.00018 \\
(0.00020)\end{array}$ & $9.73 \%$ & $\begin{array}{l}-0.01678 * \\
(0.00894)\end{array}$ & $-1.80 \%$ & $\begin{array}{r}0.00396 \\
(0.00712)\end{array}$ & $17.93 \%$ \\
\hline 57-59 years old & $\begin{array}{l}0.00152 * * * \\
(0.00031)\end{array}$ & $0.15 \%$ & $\begin{array}{l}-0.00093 * * * \\
(0.00018)\end{array}$ & $-37.05 \%$ & $\begin{array}{l}-0.02555 * * * \\
(0.00949)\end{array}$ & $-2.69 \%$ & $\begin{array}{r}0.00927 \\
(0.00609)\end{array}$ & $81.89 \%$ \\
\hline 60-62 years old & $\begin{array}{r}0.00058 \\
(0.00073)\end{array}$ & $0.06 \%$ & $\begin{array}{l}-0.00056 * \\
(0.00031)\end{array}$ & $-16.72 \%$ & $\begin{array}{r}-0.00973 \\
(0.00773)\end{array}$ & $-1.02 \%$ & $\begin{array}{c}0.00698 * \\
(0.00402)\end{array}$ & $204.09 \%$ \\
\hline 63-64 years old & $\begin{array}{r}0.00076 \\
(0.00183)\end{array}$ & $0.08 \%$ & $\begin{array}{r}-0.00042 \\
(0.00037)\end{array}$ & $-19.00 \%$ & $\begin{array}{l}-0.02592 * * \\
(0.01090)\end{array}$ & $-2.79 \%$ & $\begin{array}{r}0.00349 \\
(0.00420)\end{array}$ & $168.60 \%$ \\
\hline
\end{tabular}

\section{Controls:}

Age, gender, state of residence

Linear and quadratic trends x state, month

and year effects

Retirement controls

Anticipation controls

Unemployment benefit controls

$\begin{array}{cc}\text { yes } & \text { yes } \\ \text { yes } & \text { yes } \\ \text { yes } & \text { yes } \\ \text { yes } & \text { yes } \\ \text { no } & \text { no }\end{array}$

$1,201,836$

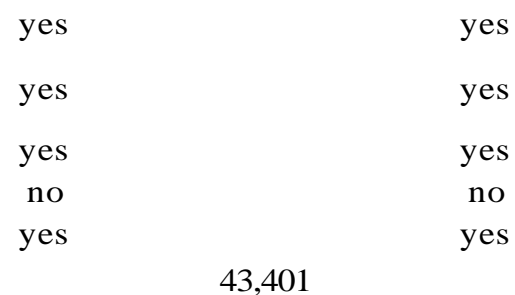

Note: Standard errors are clustered at the individual level. ***: $\mathrm{p}<1 \%$; **: $\mathrm{p}<5 \%$; : p $<10 \%$. RME are calculated as the relation of the age-specific marginal effect and the mean probability of the transition in the pre-reform period for the specific age group. Pre-reform period: Transitions from $E=03 / 2004$-08/2005; Transitions from U=03/2004 -01/2006. Anticipation period: Transitions from E=09/2005 - 01/2006. Post-reform period: 02/2006 12/2007. Estimations include main reform effect “post-reform”. For a list and definition of control variables, see Table 3.

Source: SIAB 7510 and own calculations. 
Table A.14 Logit coefficients of the reform effects on labor market transitions controlling for retirement, anticipation, and employment benefits: extended pooled sample

\begin{tabular}{|c|c|c|c|c|}
\hline & $\begin{array}{l}\text { E-E transitions } \\
\text { (1) }\end{array}$ & $\begin{array}{l}\text { E-U transitions } \\
\text { (2) }\end{array}$ & $\begin{array}{l}\text { U-U transitions } \\
\text { (3) }\end{array}$ & $\begin{array}{c}\text { U-E transitions } \\
\text { (4) }\end{array}$ \\
\hline Post-reform & $\begin{array}{l}-0.3998 * * * \\
(0.0473)\end{array}$ & $\begin{array}{l}0.6957 * * * \\
(0.0703)\end{array}$ & $\begin{array}{r}-0.0420 \\
(0.0304)\end{array}$ & $\begin{array}{l}-0.1266 * * * \\
(0.0360)\end{array}$ \\
\hline Post-reform x 45 -46 years old & $\begin{array}{r}0.0148 \\
(0.0376)\end{array}$ & $\begin{array}{r}-0.0502 \\
(0.0511)\end{array}$ & $\begin{array}{l}-0.2541 * * * \\
(0.0537)\end{array}$ & $\begin{array}{l}0.1063 * \\
(0.0581)\end{array}$ \\
\hline Post-reform x 47-51 years old & $\begin{array}{l}0.0485 * \\
(0.0270)\end{array}$ & $\begin{array}{l}-0.1247 * * * \\
(0.0364)\end{array}$ & $\begin{array}{l}-0.4893 * * * \\
(0.0430)\end{array}$ & $\begin{array}{r}0.0581 \\
(0.0440)\end{array}$ \\
\hline Post-reform x $52-54$ years old & $\begin{array}{l}0.1115 * * * \\
(0.0321)\end{array}$ & $\begin{array}{l}-0.1808 * * * \\
(0.0442)\end{array}$ & $\begin{array}{l}-0.7354 * * * \\
(0.0507)\end{array}$ & $\begin{array}{l}0.1920 * * * \\
(0.0543)\end{array}$ \\
\hline Post-reform x 55-56 years old & $\begin{array}{r}0.0366 \\
(0.0379)\end{array}$ & $\begin{array}{l}-0.1223 * * \\
(0.0539)\end{array}$ & $\begin{array}{l}-0.6305 * * * \\
(0.0605)\end{array}$ & $\begin{array}{l}0.1265 * \\
(0.0721)\end{array}$ \\
\hline Post-reform x 57-59 years old & $\begin{array}{l}0.2264 * * * \\
(0.0319)\end{array}$ & $\begin{array}{l}-0.3324 * * * \\
(0.0474)\end{array}$ & $\begin{array}{l}-0.6322 * * * \\
(0.0572)\end{array}$ & $\begin{array}{l}0.4952 * * * \\
(0.0786)\end{array}$ \\
\hline Post-reform x 60-62 years old & $\begin{array}{r}0.0428 \\
(0.0288)\end{array}$ & $\begin{array}{l}-0.2170 * * * \\
(0.0552)\end{array}$ & $\begin{array}{l}-0.5229 * * * \\
(0.0683)\end{array}$ & $\begin{array}{l}0.5909 * * * \\
(0.1278)\end{array}$ \\
\hline Post-reform x 63-64 years old & $\begin{array}{l}0.0876 * * \\
(0.0368)\end{array}$ & $\begin{array}{r}-0.1148 \\
(0.1165)\end{array}$ & $\begin{array}{l}-0.3629 * * * \\
(0.0963)\end{array}$ & $\begin{array}{l}0.5933 * * \\
(0.2955)\end{array}$ \\
\hline Controls: & & & & \\
\hline $\begin{array}{l}\text { Age, gender, education, state of } \\
\text { residence }\end{array}$ & yes & yes & yes & yes \\
\hline $\begin{array}{l}\text { Linear and quadratic trends x state, } \\
\text { month and year effects }\end{array}$ & yes & yes & yes & yes \\
\hline Retirement controls & yes & yes & yes & yes \\
\hline Anticipation controls & yes & yes & no & no \\
\hline Unemployment benefit controls & no & no & yes & yes \\
\hline $\mathrm{N}$ & \multicolumn{2}{|c|}{$8,615,029$} & \multicolumn{2}{|c|}{525,562} \\
\hline Mean & 0.9923 & 0.0034 & 0.9124 & 0.0347 \\
\hline
\end{tabular}

Note: Standard errors are clustered at the individual level. ***: $\mathrm{p}<1 \%$; ** $\mathrm{p}<5 \%$; *: $\mathrm{p}<10 \%$. Pre-reform period: Transitions from E=03/2004 -08/2005; Transitions from U=03/2004 01/2006. Anticipation period: Transitions from E=09/2005 - 01/2006. Post-reform period: 02/2006 - 12/2007. For a list and definition of control variables, see Table 3.

Source: SIAB 7510 and own calculations. 
Table A.15 Logit coefficients of the reform effects on labor market transitions controlling for retirement, anticipation, and employment benefits: pooled sample without FebruaryJuly 2006

\begin{tabular}{|c|c|c|c|c|}
\hline & $\begin{array}{c}\text { E-E transitions } \\
\text { (1) }\end{array}$ & $\begin{array}{c}\text { E-U transitions } \\
\text { (2) }\end{array}$ & $\begin{array}{l}\text { U-U transitions } \\
\text { (3) }\end{array}$ & $\begin{array}{l}\text { U-E transitions } \\
\text { (4) } \\
\end{array}$ \\
\hline Post-reform & $\begin{array}{l}-0.3074 * * * \\
(0.0568)\end{array}$ & $\begin{array}{l}0.5622 * * * \\
(0.0902)\end{array}$ & $\begin{array}{r}-0.0237 \\
(0.0393)\end{array}$ & $\begin{array}{l}-0.1707 * * * \\
(0.0520)\end{array}$ \\
\hline Post-reform x 45-46 years old & $\begin{array}{r}0.0067 \\
(0.0436)\end{array}$ & $\begin{array}{r}-0.0316 \\
(0.0604)\end{array}$ & $\begin{array}{l}-0.2893 * * * \\
(0.0642)\end{array}$ & $\begin{array}{l}0.1427 * * \\
(0.0703)\end{array}$ \\
\hline Post-reform x 47-51 years old & $\begin{array}{r}0.0223 \\
(0.0328)\end{array}$ & $\begin{array}{l}-0.1120 * * \\
(0.0462)\end{array}$ & $\begin{array}{l}-0.6088 * * * \\
(0.0533)\end{array}$ & $\begin{array}{r}0.0918 \\
(0.0576)\end{array}$ \\
\hline Post-reform x 52-54 years old & $\begin{array}{r}0.0621 \\
(0.0397)\end{array}$ & $\begin{array}{l}-0.1271 * * \\
(0.0581)\end{array}$ & $\begin{array}{l}-0.9321 * * * \\
(0.0651)\end{array}$ & $\begin{array}{l}0.2721 * * * \\
(0.0733)\end{array}$ \\
\hline Post-reform x 55-56 years old & $\begin{array}{r}-0.0043 \\
(0.0439)\end{array}$ & $\begin{array}{r}-0.0420 \\
(0.0646)\end{array}$ & $\begin{array}{l}-0.7676 * * * \\
(0.0727)\end{array}$ & $\begin{array}{l}0.1805 * * \\
(0.0917)\end{array}$ \\
\hline Post-reform x 57-59 years old & $\begin{array}{l}0.2395 * * * \\
(0.0387)\end{array}$ & $\begin{array}{l}-0.2957 * * * \\
(0.0603)\end{array}$ & $\begin{array}{l}-0.6738 * * * \\
(0.0702)\end{array}$ & $\begin{array}{l}0.5634 * * * \\
(0.1110)\end{array}$ \\
\hline Post-reform x 60-62 years old & $\begin{array}{r}0.0256 \\
(0.0340)\end{array}$ & $\begin{array}{l}-0.2203 * * * \\
(0.0687)\end{array}$ & $\begin{array}{l}-0.6498 * * * \\
(0.0826)\end{array}$ & $\begin{array}{l}0.5442 * * * \\
(0.1831)\end{array}$ \\
\hline Post-reform x 63-64 years old & $\begin{array}{l}0.0821 * * \\
(0.0410)\end{array}$ & $\begin{array}{r}0.0137 \\
(0.1340)\end{array}$ & $\begin{array}{l}-0.4460 * * * \\
(0.1078)\end{array}$ & $\begin{array}{r}0.2097 \\
(0.4699)\end{array}$ \\
\hline Controls: & & & & \\
\hline $\begin{array}{l}\text { Age, gender, education, state of } \\
\text { residence }\end{array}$ & yes & yes & yes & yes \\
\hline $\begin{array}{l}\text { Linear and quadratic trends xstate, } \\
\text { month and year effects }\end{array}$ & yes & yes & yes & yes \\
\hline Retirement controls & yes & yes & yes & yes \\
\hline Anticipation controls & yes & yes & no & no \\
\hline Unemployment benefit controls & no & no & yes & yes \\
\hline $\mathrm{N}$ & \multicolumn{2}{|c|}{$6,980,023$} & \multicolumn{2}{|c|}{368,752} \\
\hline Mean & 0.9932 & 0.0027 & 0.9194 & 0.0288 \\
\hline
\end{tabular}

Note: Standard errors are clustered at the individual level. ***: $\mathrm{p}<1 \%$; **: $\mathrm{p}<5 \%$; * $\mathrm{p}<10 \%$. Pre-reform period: Transitions from E=03/2004 -08/2005; Transitions from U=03/2004 01/2006. Anticipation period: Transitions from E=09/2005 - 01/2006. Post-reform period: 02/2006 - 12/2007. For a list and definition of control variables, see Table 3.

Source: SIAB 7510 and own calculations. 
Table A.16 Logit coefficients of the reform effects on labor market transitions controlling for retirement, anticipation and unemployment benefits: transitions from unemployment for those unemployed less than 1 year

\begin{tabular}{|c|c|c|}
\hline & $\begin{array}{l}\text { U-U transitions } \\
\text { (3) }\end{array}$ & $\begin{array}{c}\text { U-E transitions } \\
\text { (4) }\end{array}$ \\
\hline Post-reform & $\begin{array}{l}0.1214 * * * \\
(0.0379)\end{array}$ & $\begin{array}{l}-0.1106 * * \\
(0.048)\end{array}$ \\
\hline Post-reform x 45-46 years old & $\begin{array}{l}.0 .2561 * * * \\
(0.0542)\end{array}$ & $\begin{array}{l}0.1498 * * \\
(0.0665)\end{array}$ \\
\hline Post-reform x 47-51 years old & $\begin{array}{l}-0.5187 * * * \\
(0.0465)\end{array}$ & $\begin{array}{l}0.1019 * \\
(0.0553)\end{array}$ \\
\hline Post-reform x 52-54 years old & $\begin{array}{l}-0.7170 * * * \\
(0.0581)\end{array}$ & $\begin{array}{l}0.3088 * * * \\
(0.0731)\end{array}$ \\
\hline Post-reform x 55-56 years old & $\begin{array}{l}-0.5741 * * * \\
(0.0739)\end{array}$ & $\begin{array}{l}0.2372 * * \\
(0.0937)\end{array}$ \\
\hline Post-reform x 57-59 years old & $\begin{array}{l}-0.6211 * * * \\
(0.0834)\end{array}$ & $\begin{array}{l}0.5546 * * * \\
(0.1234)\end{array}$ \\
\hline Post-reform x 60-62 years old & $\begin{array}{l}-0.3555 * * * \\
(0.1124)\end{array}$ & $\begin{array}{l}0.3760 * \\
(0.2186)\end{array}$ \\
\hline Post-reform x 63-64 years old & $\begin{array}{r}0.2218 \\
(0.1689)\end{array}$ & $\begin{array}{r}-0.5577 \\
(0.5808)\end{array}$ \\
\hline Controls: & & \\
\hline $\begin{array}{l}\text { Age, gender, education, state of } \\
\text { residence }\end{array}$ & yes & yes \\
\hline $\begin{array}{l}\text { Linear and quadratic trends x state, } \\
\text { month and year effects }\end{array}$ & yes & yes \\
\hline Retirement controls & yes & yes \\
\hline Anticipation controls & no & no \\
\hline Unemployment benefit controls & yes & yes \\
\hline $\mathrm{N}$ & \multicolumn{2}{|c|}{261,589} \\
\hline Mean & 0.9205 & 0.0402 \\
\hline
\end{tabular}

Note: Standard errors are clustered at the individual level. ***: $\mathrm{p}<1 \%$; *: $\mathrm{p}<5 \%$; * $\mathrm{p}<10 \%$. Pre-reform period: Transitions from E=03/2004 -08/2005; Transitions from U=03/2004 01/2006. Anticipation period: Transitions from E=09/2005 - 01/2006. Post-reform period: 02/2006 - 12/2007. For a list and definition of control variables, see Table 3. Source: SIAB 7510 and own calculations. 
Table A.17 Logit coefficients of the reform effects on labor market transitions controlling for retirement, anticipation and unemployment benefits: transitions from employment omitting observations aged 45, 47, 52, 55, and 57

\begin{tabular}{lcc}
\hline & E-E transitions & E-U transitions \\
& $(3)$ & $(4)$ \\
\hline Post-reform & $-0.3573 * * *$ & $0.7369 * * *$ \\
& $(0.0576)$ & $(0.0941)$ \\
Post-reform x 46 years old & 0.0334 & -0.1126 \\
& $(0.0538)$ & $(0.0746)$ \\
Post-reform x 48-51 years old & 0.1322 & $-0.1167 * *$ \\
& $(0.0431)$ & $(0.0453)$ \\
Post-reform x 53-54 years old & 0.0010 & $-0.2063 * * *$ \\
& $(0.0548)$ & $(0.0640)$ \\
Post-reform x 56 years old & 0.0010 & -0.0642 \\
& $(0.0548)$ & $(0.0805)$ \\
Post-reform x 58-59 years old & $0.2205 * * *$ & -0.2802 \\
& $(0.0405)$ & $(0.0664)$ \\
Post-reform x 60-62 years old & 0.0353 & $-0.2695 * * *$ \\
& $(0.0313)$ & $(0.0624)$ \\
Post-reform x 63-64 years old & $0.0657 *$ & -0.0746 \\
& $(0.0392)$ & $(0.1287)$ \\
\hline Controls: & & \\
Age, gender, education, state of & yes & yes \\
residence & & \\
Linear and quadratic trends x state , & yes & yes \\
month and year effects & yes & yes \\
Retirement controls & no & yes \\
Anticipation controls & yes & 0.0027 \\
Unemployment benefit controls & 0.9928 & \\
N & & \\
Mean & & \\
\hline
\end{tabular}

Note: Standard errors are clustered at the individual level. ***: $\mathrm{p}<1 \%$; **: $\mathrm{p}<5 \%$; *: $\mathrm{p}<10 \%$. Pre-reform period: Transitions from E=03/2004 -08/2005; Transitions from U=03/2004 01/2006. Anticipation period: Transitions from E=09/2005 - 01/2006. Post-reform period: 02/2006 - 12/2007. For a list and definition of control variables, see Table 3. Source: SIAB 7510 and own calculations. 
Table A.18 Logit coefficients of the reform effects on labor market transitions controlling for the duration in the ongoing employment spell

\begin{tabular}{lcc}
\hline & E-E transitions & E-U transitions \\
& $(3)$ & $(4)$ \\
\hline Post-reform & $-0.3402 * * *$ & $0.6759 * * *$ \\
& $(0.0529)$ & $(0.0843)$ \\
Post-reform x 45-46 years old & -0.0287 & -0.0021 \\
& $(0.0403)$ & $(0.0554)$ \\
Post-reform x 47-51 years old & 0.0061 & $-0.0948 * *$ \\
& $(0.0305)$ & $(0.0426)$ \\
Post-reform x 52-54 years old & 0.0438 & -0.1142 \\
& $(0.0368)$ & $(0.0532)$ \\
Post-reform x 55-56 years old & -0.0071 & -0.0649 \\
& $(0.0410)$ & $(0.0600)$ \\
Post-reform x 57-59 years old & $0.1901 * * *$ & $-0.3582 * * *$ \\
& $(0.0358)$ & $(0.0561)$ \\
Post-reform x 60-62 years old & 0.0186 & $-0.2495 * * *$ \\
& $(0.0316)$ & $(0.0633)$ \\
Post-reform x 63-64 years old & 0.0223 & 0.0239 \\
& $(0.0401)$ & $(0.1293)$ \\
\hline Controls: & & \\
Age, gender, education, state of & yes & yes \\
residence & & \\
Linear and quadratic trends x state, & yes & yes \\
month and year effects & yes & yes \\
Retirement controls & no & yes \\
Anticipation controls & 0.9933 & 0.0026 \\
Unemployment benefit controls & yes & \\
N & & \\
Mean & & \\
\hline
\end{tabular}

Note: Standard errors are clustered at the individual level. ***: $\mathrm{p}<1 \%$; ** $\mathrm{p}<5 \%$; *: $\mathrm{p}<10 \%$. Pre-reform period: Transitions from E=03/2004 -08/2005; Transitions from U=03/2004 01/2006. Anticipation period: Transitions from E=09/2005 - 01/2006. Post-reform period: 02/2006 - 12/2007. For a list and definition of control variables, see Table 3.

Source: SIAB 7510 and own calculations. 
Table A.19 Logit coefficients of the reform effects on labor market transitions controlling for retirement, anticipation, and employment benefits: pooled sample with different clustered standard errors

\begin{tabular}{|c|c|c|c|c|}
\hline & $\begin{array}{c}\text { E-E transitions } \\
\text { (1) } \\
\end{array}$ & $\begin{array}{c}\text { E-U transitions } \\
\text { (2) }\end{array}$ & $\begin{array}{l}\text { U-U transitions } \\
\text { (3) }\end{array}$ & $\begin{array}{c}\text { U-E transitions } \\
\text { (4) }\end{array}$ \\
\hline Post-reform & $\begin{array}{l}-0.3446 * * * \\
(0.0892)\end{array}$ & $\begin{array}{l}0.6785 * * * \\
(0.1048)\end{array}$ & $\begin{array}{r}-0.0558 \\
(0.0592)\end{array}$ & $\begin{array}{l}-0.1075 * * \\
(0.0547)\end{array}$ \\
\hline Post-reform x 45-46 years old & $\begin{array}{r}-0.0188 \\
(0.0629)\end{array}$ & $\begin{array}{r}-0.0235 \\
(0.0482)\end{array}$ & $\begin{array}{l}-0.2966 * * * \\
(0.1045)\end{array}$ & $\begin{array}{l}0.1570 * * \\
(0.0654)\end{array}$ \\
\hline Post-reform x 47-51 years old & $\begin{array}{r}0.0297 \\
(0.0600)\end{array}$ & $\begin{array}{l}-0.1372 * * * \\
(0.0503)\end{array}$ & $\begin{array}{l}-0.6259 * * * \\
(0.0717)\end{array}$ & $\begin{array}{l}0.1130 * \\
(0.0584)\end{array}$ \\
\hline Post-reform x 52-54 years old & $\begin{array}{r}0.0117 \\
(0.0721)\end{array}$ & $\begin{array}{r}-0.0761 \\
(0.0559)\end{array}$ & $\begin{array}{l}-0.9036 * * * \\
(0.0835)\end{array}$ & $\begin{array}{l}0.2509 * * * \\
(0.0829)\end{array}$ \\
\hline Post-reform x 55-56 years old & $\begin{array}{r}-0.0160 \\
(0.0690)\end{array}$ & $\begin{array}{r}-0.0484 \\
(0.0558)\end{array}$ & $\begin{array}{l}-0.7611 * * * \\
(0.0939)\end{array}$ & $\begin{array}{l}0.2039 * * * \\
(0.0726)\end{array}$ \\
\hline Post-reform x 57-59 years old & $\begin{array}{r}0.1627 \\
(0.2601)\end{array}$ & $\begin{array}{l}-0.3212 * * * \\
(0.0698)\end{array}$ & $\begin{array}{l}-0.6600 * * * \\
(0.1075)\end{array}$ & $\begin{array}{l}0.5074 * * * \\
(0.1081)\end{array}$ \\
\hline Post-reform x 60-62 years old & $\begin{array}{r}0.0391 \\
(0.1970)\end{array}$ & $\begin{array}{l}-0.2801 * * * \\
(0.0544)\end{array}$ & $\begin{array}{l}-0.6230 * * * \\
(0.0957)\end{array}$ & $\begin{array}{l}0.5939 * * * \\
(0.1643)\end{array}$ \\
\hline Post-reform x 63-64 years old & $\begin{array}{r}0.1066 \\
(0.2109)\end{array}$ & $\begin{array}{r}-0.1126 \\
(0.1621)\end{array}$ & $\begin{array}{l}-0.4766 * * * \\
(0.1094)\end{array}$ & $\begin{array}{r}-0.0053 \\
(0.2530)\end{array}$ \\
\hline Controls: & & & & \\
\hline $\begin{array}{l}\text { Age, gender, education, state of } \\
\text { residence }\end{array}$ & yes & yes & yes & yes \\
\hline $\begin{array}{l}\text { Linear and quadratic trends x state, } \\
\text { month and year effects }\end{array}$ & yes & yes & yes & yes \\
\hline Retirement controls & yes & yes & yes & yes \\
\hline Anticipation controls & yes & yes & no & no \\
\hline Unemployment benefit controls & no & no & yes & yes \\
\hline $\mathrm{N}$ & \multicolumn{2}{|c|}{$8,020,998$} & \multicolumn{2}{|c|}{430,301} \\
\hline Mean & 0.9933 & 0.0026 & 0.9200 & 0.0289 \\
\hline
\end{tabular}

Note: Standard errors are clustered at the birth cohort-by-year-level. ***: p < ${ }^{*}$; **: $\mathrm{p}<5 \%$; *: p $<10 \%$. Pre-reform period: Transitions from E=03/2004 -08/2005; Transitions from $\mathrm{U}=03 / 2004-01 / 2006$. Anticipation period: Transitions from $E=09 / 2005-01 / 2006$. Postreform period: 02/2006 - 12/2007. For a list and definition of control variables, see Table 3. Source: SIAB 7510 and own calculations. 
Table A.20 Probit coefficients of the reform effects on labor market transitions controlling for retirement, anticipation, and employment benefits: pooled sample

\begin{tabular}{|c|c|c|c|c|}
\hline & $\begin{array}{c}\text { E-E transitions } \\
\text { (1) } \\
\end{array}$ & $\begin{array}{l}\text { E-U transitions } \\
\text { (2) }\end{array}$ & $\begin{array}{l}\text { U-U transitions } \\
\text { (3) }\end{array}$ & $\begin{array}{c}\text { U-E transitions } \\
\text { (4) }\end{array}$ \\
\hline Post-reform & $\begin{array}{l}-0.1314 * * * \\
(0.0187)\end{array}$ & $\begin{array}{l}0.2271 * * * \\
(0.0268)\end{array}$ & $\begin{array}{l}-0.0315 * \\
(0.0167)\end{array}$ & $\begin{array}{r}0.0232 \\
(0.0181)\end{array}$ \\
\hline Post-reform x 45-46 years old & $\begin{array}{r}-0.0073 \\
(0.0139)\end{array}$ & $\begin{array}{r}-0.0058 \\
(0.0179)\end{array}$ & $\begin{array}{l}-0.1404 * * * \\
(0.0302)\end{array}$ & $\begin{array}{l}0.0695 * * \\
(0.0319)\end{array}$ \\
\hline Post-reform x 47-51 years old & $\begin{array}{r}0.0060 \\
(0.0105)\end{array}$ & $\begin{array}{l}-0.0382 * * * \\
(0.0137)\end{array}$ & $\begin{array}{l}-0.2720 * * * \\
(0.0247)\end{array}$ & $\begin{array}{l}0.0423 * \\
(0.0256)\end{array}$ \\
\hline Post-reform x 52-54 years old & $\begin{array}{l}0.0210 * \\
(0.0128)\end{array}$ & $\begin{array}{l}-0.0396 * * \\
(0.0171)\end{array}$ & $\begin{array}{l}-0.4116 * * * \\
(0.0295)\end{array}$ & $\begin{array}{l}0.1188 * * * \\
(0.0317)\end{array}$ \\
\hline Post-reform x 55-56 years old & $\begin{array}{r}0.0020 \\
(0.0144)\end{array}$ & $\begin{array}{r}-0.0223 \\
(0.0194)\end{array}$ & $\begin{array}{l}-0.3333 * * * \\
(0.0332)\end{array}$ & $\begin{array}{l}0.0738 * * \\
(0.0377)\end{array}$ \\
\hline Post-reform x 57-59 years old & $\begin{array}{l}0.0770 * * * \\
(0.0129)\end{array}$ & $\begin{array}{l}-0.1187 * * * \\
(0.0183)\end{array}$ & $\begin{array}{l}-0.3076 * * * \\
(0.0322)\end{array}$ & $\begin{array}{l}0.1635 * * * \\
(0.0412)\end{array}$ \\
\hline Post-reform x 60-62 years old & $\begin{array}{l}0.0217 * \\
(0.0121)\end{array}$ & $\begin{array}{l}-0.0956 * * * \\
(0.0209)\end{array}$ & $\begin{array}{l}-0.2668 * * * \\
(0.0374)\end{array}$ & $\begin{array}{l}0.1535 * * \\
(0.0626)\end{array}$ \\
\hline Post-reform x 63-64 years old & $\begin{array}{l}0.0444 * * * \\
(0.0169)\end{array}$ & $\begin{array}{r}-0.0269 \\
(0.0425)\end{array}$ & $\begin{array}{l}-0.1552 * * * \\
(0.0503)\end{array}$ & $\begin{array}{r}-0.0626 \\
(0.1454)\end{array}$ \\
\hline Controls: & & & & \\
\hline $\begin{array}{l}\text { Age, gender, education, state of } \\
\text { residence }\end{array}$ & yes & yes & yes & yes \\
\hline $\begin{array}{l}\text { Linear and quadratic trends x state, } \\
\text { month and year effects }\end{array}$ & yes & yes & yes & yes \\
\hline Retirement controls & yes & yes & yes & yes \\
\hline Anticipation controls & yes & yes & no & no \\
\hline Unemployment benefit controls & no & no & yes & yes \\
\hline $\mathrm{N}$ & \multicolumn{2}{|c|}{$8,020,998$} & \multicolumn{2}{|c|}{430,301} \\
\hline Mean & 0.9933 & 0.0026 & 0.9200 & 0.0289 \\
\hline
\end{tabular}

Note: Standard errors are clustered at the individual level. ***: $\mathrm{p}<1 \%$; **: $\mathrm{p}<5 \%$; *: $\mathrm{p}<10 \%$. Pre-reform period: Transitions from E=03/2004 -08/2005; Transitions from U=03/2004 01/2006. Anticipation period: Transitions from E=09/2005 - 01/2006. Post-reform period: 02/2006 - 12/2007. For a list and definition of control variables, see Table 3.

Source: SIAB 7510 and own calculations. 
Table A.21 Cloglog coefficients of the reform effects on labor market transitions controlling for retirement, anticipation, and employment benefits: pooled sample

\begin{tabular}{|c|c|c|c|c|}
\hline & $\begin{array}{c}\text { E-E transitions } \\
\text { (1) } \\
\end{array}$ & $\begin{array}{c}\text { E-U transitions } \\
\text { (2) }\end{array}$ & $\begin{array}{c}\text { U-U transitions } \\
\text { (3) }\end{array}$ & $\begin{array}{c}\text { U-E transitions } \\
\text { (4) }\end{array}$ \\
\hline Post-reform & $\begin{array}{l}-0.0749 * * * \\
(0.0104)\end{array}$ & $\begin{array}{l}0.6839 * * * \\
(0.0840)\end{array}$ & $\begin{array}{l}-0.0344 * * * \\
(0.0122)\end{array}$ & $\begin{array}{r}0.0104 \\
(0.0367)\end{array}$ \\
\hline Post-reform x 45-46 years old & $\begin{array}{r}-0.0039 \\
(0.0076)\end{array}$ & $\begin{array}{r}-0.0204 \\
(0.0554)\end{array}$ & $\begin{array}{l}-0.0991 * * * \\
(0.0226)\end{array}$ & $\begin{array}{l}0.1427 * * \\
(0.0629)\end{array}$ \\
\hline Post-reform x 47-51 years old & $\begin{array}{r}0.0032 \\
(0.0058)\end{array}$ & $\begin{array}{l}-0.1228 * * * \\
(0.0424)\end{array}$ & $\begin{array}{l}-0.1744 * * * \\
(0.0180)\end{array}$ & $\begin{array}{l}0.1025 * * \\
(0.0519)\end{array}$ \\
\hline Post-reform x 52-54 years old & $\begin{array}{r}0.0115 \\
(0.0070)\end{array}$ & $\begin{array}{l}-0.1226 * * \\
(0.0529)\end{array}$ & $\begin{array}{l}-0.2667 * * * \\
(0.0211)\end{array}$ & $\begin{array}{l}0.2774 * * * \\
(0.0666)\end{array}$ \\
\hline Post-reform x 55-56 years old & $\begin{array}{r}0.0013 \\
(0.0080)\end{array}$ & $\begin{array}{r}-0.0670 \\
(0.0596)\end{array}$ & $\begin{array}{l}-0.2050 * * * \\
(0.0234)\end{array}$ & $\begin{array}{l}0.2230 * * * \\
(0.0844)\end{array}$ \\
\hline Post-reform x 57-59 years old & $\begin{array}{l}0.0446 * * * \\
(0.0073)\end{array}$ & $\begin{array}{l}-0.3606 * * * \\
(0.0557)\end{array}$ & $\begin{array}{l}-0.1959 * * * \\
(0.0224)\end{array}$ & $\begin{array}{l}0.5325 * * * \\
(0.1027)\end{array}$ \\
\hline Post-reform x 60-62 years old & $\begin{array}{l}0.0155 * * \\
(0.0073)\end{array}$ & $\begin{array}{l}-0.2801 * * * \\
(0.0624)\end{array}$ & $\begin{array}{l}-0.1543 * * * \\
(0.0257)\end{array}$ & $\begin{array}{l}0.6031 * * * \\
(0.1766)\end{array}$ \\
\hline Post-reform x 63-64 years old & $\begin{array}{l}0.0360 * * * \\
(0.0112)\end{array}$ & $\begin{array}{r}-0.0764 \\
(0.1284)\end{array}$ & $\begin{array}{r}-0.0520 \\
(0.0352)\end{array}$ & $\begin{array}{r}0.0109 \\
(0.4531)\end{array}$ \\
\hline Controls: & & & & \\
\hline $\begin{array}{l}\text { Age, gender, education, state of } \\
\text { residence }\end{array}$ & yes & yes & yes & yes \\
\hline $\begin{array}{l}\text { Linear and quadratic trends x state, } \\
\text { month and year effects }\end{array}$ & yes & yes & yes & yes \\
\hline Retirement controls & yes & yes & yes & yes \\
\hline Anticipation controls & yes & yes & no & no \\
\hline Unemployment benefit controls & no & no & yes & yes \\
\hline $\mathrm{N}$ & \multicolumn{2}{|c|}{$8,020,998$} & \multicolumn{2}{|c|}{430,301} \\
\hline Mean & 0.9933 & 0.0026 & 0.9200 & 0.0289 \\
\hline
\end{tabular}

Note: Standard errors are clustered at the individual level. ***: $\mathrm{p}<1 \%$; **: $\mathrm{p}<5 \%$; *: $\mathrm{p}<10 \%$. Pre-reform period: Transitions from E=03/2004 -08/2005; Transitions from U=03/2004 01/2006. Anticipation period: Transitions from E=09/2005 - 01/2006. Post-reform period: 02/2006 - 12/2007. For a list and definition of control variables, see Table 3.

Source: SIAB 7510 and own calculations. 


\section{Appendix B}

\section{B.1 Sample restriction and labor force status}

\section{Sample restriction}

We restrict our sample to individuals who are eligible resp. would have been eligible for the maximum duration of unemployment benefits under the pre-reform regime as they are fully affected by the reform. Under the pre-reform regime, unemployment benefit eligibility required that the individual had been employed for at least 12 months within the last 3 years or since the last receipt of unemployment benefits within the last 3 years. To be eligible for the maximum transfer duration, the individual needed up to 64 months of employment within the last 7 years or since the last receipt of unemployment benefits within the last 7 years.

\section{Definition of labor force status}

State $E$ describes individuals who are in an employment relationship paying mandatory social security contributions. This does not include individuals in training, in early retirement, interns, protected disabled individuals in special employment situations, marginal employments, and those in civil and military service.

State $U$ describes individuals who receive unemployment benefits (Arbeitslosengeld I). Jung and Kuhn (2014) discuss that this definition of $U$ differs from the one applied in analyses for the United States, where unemployment is associated with search rather than benefit receipt. In those few instances, when the data suggest simultaneous employment and unemployment spells, we follow the data producers' recommendations and code employment as this is the more reliable information (see Jaenichen et al. 2005).

State $O$ describes individuals who left the labor market, who exited from their last spell, or who have gaps of more than 12 weeks between $\mathrm{E}$ and $\mathrm{U}$ spells.

Gaps between spells: We code gaps of up to 12 weeks between $\mathrm{E}$ and $\mathrm{U}$ as well as between two U spells as direct transitions which take place immediately after the first spell because individuals who voluntarily quit a job or fail to report to the UI in time can be sanctioned by a delay of up to 12 weeks in the start of their benefit payouts (see Fitzenberger and Wilke 2009). In that case, they would be unemployed (without benefits) already up to 12 weeks prior to the start of the payout spell. Similarly, we coded gaps of up to 12 weeks between $U$ and E spells and two E spells as direct transitions. Since 2005, the data informs on whether individuals were sanctioned.

Gaps of more than 12 weeks between spells suggest that the individual left the labor force, as otherwise the individual has an incentive to claim unemployment benefits. For gaps of more than 12 weeks and for the last spell of an individual's employment biography that does not end by death we add out-of-the labor force spells to the data (coded $\mathrm{O}$ ). This definition has some limitations as we might be miscoding periods such as self-employment - which we cannot recognize in the data - or marginal employment as O. However, this is the only possibility to consider labor force exits - besides death - in our analysis. Spells of individuals who receive unemployment benefits II (Hartz IV) are also coded as O unless individuals are employed (state E) or receive unemployment benefits (state $\mathrm{U}$ ) at the same time. 


\section{B.2 Control variables}

\section{Education groups:}

The education information provided in SIAB is at times inconsistent and missing. In order to correct for the inconsistencies and to "fill" missing values we chose an imputation method similar to method IP I suggested by Fitzenberger et al. (2006). We fill missing education values in the future with observations from the past assuming that educational degrees cannot be lost. In order to maintain observations without education information in the data, we code and control for a missing information indicator.

\section{Retirement controls:}

Early and full retirement: Variable is coded 1 if the individual is either eligible for early (full) retirement due to unemployment or for early (full) retirement for women at the time of transition.

As an eligibility condition for early (full) retirement due to unemployment, the individual has to fulfill the following criteria:

- have the respective minimum age for early (full) retirement valid for their birth cohort,

- have paid pension contributions for at least 8 years in the last 10 years before the start of retirement,

- have paid pension contributions for at least 15 years in total and

- have been unemployed for at least 52 weeks from the age of 58.5 years or have reduced their working time due to partial retirement for at least 24 months.

To be eligible for early (full) retirement for women, the individual has to fulfill the following criteria:

- have the respective minimum age for early (full) retirement valid for their birth cohort,

- have paid pension contributions for more than 10 years from the age of 40 and

- have paid pension contributions for at least 15 years in total.

Distance to early and full retirement: Variable provides the number of years until an individual is eligible for any of the available early (full) retirement pathways. Eligibility is measured as reaching the birth cohort specific minimum retirement age for early (full) retirement.

\section{Anticipation controls:}

Antic: Variable is coded as 1 for transitions from E in the period September 2005 to January 2006. The 2006 UI reform affected those unemployed since February 1, 2006. Therefore, workers who were to lose their jobs on or after February 1, 2006 had an incentive to start an unemployment spell earlier. Following Dlugosz et al. (2014), we consider a short anticipation period. As the UI benefit entitlement duration depends on age and the number of insurance months prior to unemployment, if individuals quit their jobs earlier to avoid the cut in unemployment benefit payout duration they will receive fewer months of unemployment benefits. We chose for September 2005 to January 2006 as the anticipation period based on Figure 1.2. We can see there that job-exits increase from September 2005 onwards reaching a peak in December 2005.

Reg58: Variable is coded as 1 for transitions of individuals possibly affected by the end of the 58 regulation. These are transitions from E for the cohorts 1944-1949 in the period November to December 2007. The exemption from the requirement to search for work for individuals aged 58 and above expired for those entering unemployment on January 1, 2008 and after. As the termination was already announced in 2006, those aged 58 and above in 2007 (cohorts 1949 and older) had an incentive to bring an expected entry to unemployment forward and to enter unemployment prior to January 1,2008 . We do not expect to see any anticipation effects for those turning 65 in 2008 (birth cohort 1943) because they would probably enter the regular old age retirement and should not care about unemployment regulations. Again, we do not expect to see a large anticipation period because an earlier transition to unemployment probably implies a shorter unemployment benefit duration. 


\section{Unemployment benefits controls:}

Remaining UB entitlement: Variable is coded as 1 if an individual has unemployment benefit entitlements left at the time of transition. The coding is based on the variable "restanspruch" in the data which provides the remaining number of days of unemployment benefit entitlement in an unemployment spell.

Days of past UB receipt in current $U$ period: Variable is coded as the number of days an individual has received unemployment benefits in the current unemployment period prior to transition. Only days of the current unemployment episode are relevant. Days of former unemployment benefit receipts which are followed by an employment or an out-of-the-labor-force episode are not taken into account. 